(Aus dem Laboratorium der geburtshülflich-gynäkologischen Universitätsklinik in Helsingfors.)

\title{
Experimentelle Untersuchungen über die Einwirkung des Streptococcus pyogenes auf die Schleimhaut der Gebärmutter und der Scheide.
}

Von

Prof. G. Heinricius.

(Hienzel Tafel IV-IX.)

Der Zweck meiner Versuche war die Erforschung, wie die im Allgemeinen intacte Uterinschleimhaut sich gegen die Streptokokken verhält, welche Rolle das oberflächliche Epithel und das Drüsenepithel der Schleimhaut bei der Infection spielen und auf welchem Wege die Bakterien von der Gebärmutter in die Bauchhöhle bez. in den Organismus eindringen.

Nebenbei ist in einigen Versuchen die Einwirkung der Streptokokken auf die Schleimhaut der Vagina beobachtet ${ }^{1}$.

Als Versuchsthiere habe ich Kaninchen angewendet, theils weil diese Thiere im Allgemeinen für Infection durch Streptokokken emptänglich sind, theils weil, da das Kaninchen zwei Gebärmutterhörner besitzt und das eine derselben inficirt wird, man eine vergleichende Untersuchung jedes einzelnen Hornes, des inficirten und des nicht inficirten, ausführen kann.

Als Infectionsstoff habe ich eine Cultur von Streptokokken in Bouillon, die im hiesigen pathologisch-anatomischen Institut gebraucht worden war, benutzt.

1) Eine vorläufige Mittheilung über meine Versuche ist von mir auf der zehnten Versammlung der deutschen Gesellschaft für Gynäkologie zu Würzburg am 3.-6. Juni 1903 gegeben worden. 
Die Versuchsordnung ist der Hauptsache nach folgende gewesen: Nachdem das Thier mit Aether narkotisirt und am Tisch festgebunden war, wurden die Haare in der Mitte der Bauchwand geschoren, die Bauchwand mit 1 proc. Lysollösung gewaschen und mit einer in solcher Lösung befeuchteten Compresse, die eine der Linea alba entsprechende längliche Oeffnung hatte, bedeckt worden. Alsdann wurde die Bauchwand in der Mittellinie in einer Länge von $2-3 \mathrm{~cm}$ geöffnet und die inneren Geschlechtstheile durch die Bauchwand hervorgezogen.

In den 3 ersten Versuchen wurde, nachdem die inneren Geschlechtstheile durch die Bauchwunde vorgezogen waren, ein Einschnitt in den oberen Theil der hinteren Scheidenwand gemacht, worauf mittelst einer durch diese Oeffnung und durch den Muttermund bis zu einer Tiefe von etwa $2 \mathrm{~cm}$ in das Gebärmutterhorn oberhalb der Theilungsstelle eingeführten Gummikatheter die Streptokokkenbouillon eingespritzt wurde. Im Versuch 1 wurde eine Ligatur (alle Ligaturen in den Versuchen aus Seide) an der Theilungsstelle um das Horn gelegt und, unmittelbar nachdem die Bouillon eingespritzt worden war, zugezogen. Die Incisionsöffnung in der Scheidenwand wurde mittelst Suturen geschlossen, worauf die Geschlechtstheile reponirt wurden. In den Versuchen 2 und 3 wurde keine Ligatur um das Gebärmutterhorn gelegt, so dass die in dasselbe eingespritzte Streptokokkenbouillon in die Scheide hinunter getrieben werde konnte.

In den übrigen Versuchen wurde, nach Herausziehen der Geschlechtstheile durch die Bauchwunde, ein Katheter durch das Ostium vaginae: eingeführt und, unter Leitung der die Cervix uteri umfassenden Finger, durch den einen Muttermund eingeschoben, bis die Spitze gut $2 \mathrm{~cm}$ oberhalb der Theilungsstelle zu fühlen (oder zu sehen) war. In den Versuchen 4, 5, 6, 8, 9, 10, 12 und 20 wurde keine Ligatur um das injicirte Gebärmutterhorn angelegt. In den Versuchen 11, 13, 15 und 16 dagegen wurde eine um das Horn angelegte Ligatur, unmittelbar nachdem die Spitze des Katheters zurückgezogen worden war, zugezogen, damit die Streptokokkenbouillon nicht zurückgetrieben werden sollte. In den Versuchen 17, 18 und 19 wurde an zwei Stellen des Gebärmutterhornes, oberhalb und unterhalb der Stelle, wo die Injection gemacht wurde, je eine Ligatur angelegt. Die obere wurde vor der Injection zugezogen, die untere unmittelbar nach derselben. Diese Einrichtung wurde getroffen, damit die kleine Menge eingespritzter Streptokokken- 
bouillon, $0,25,0,10$ und 0,10 cem nur auf eine begrenzte Stelle des Gebärmutterhornes einwirken sollte. Zuletzt ist die Bauchwunde in zwei Etagen mit Naht geschlossen.

Die Menge der injicirten Flüssigkeit hat gleichfalls gewechselt. Bei der Injection sind nach der Berechnung folgende Mengen in die Gebärmutter eingespritzt worden: ccm 0,10 in den Versuchen $18,19,1 / 4$ in Versuch 17, $1 / 3$ in Versuch $2,1 / 2$ in den Versuchen $1,3,16,1$ in den Versuchen 4, 6, 8, 2 in den Versuchen 9, 10, $11,12,2 \frac{1}{2}$ in Versuch 15 und 3 in den Versuchen $5,13,20$. Die Menge der injicirten Flüssigkeit ist ohne Bedeutung gewesen in Bezug auf das Resultat der Injection. So wurde in den Versuchen 18 und 17, wo so geringe Mengen wie 0,10 resp. $0,25 \mathrm{ccm}$ eingespritzt wurden, kurz nach der Injection Peritonitis vorgefunden, während selbst in den Versuchen 9 und 10, wo $2 \mathrm{ccm}$ injicirt wurden, die Thiere keinen nachweisbaren Einfluss von den Streptokokken erfuhren. In den Versuchen 17 und 18 wurden freilich 2 Ligaturen um die Stelle gelegt, wohin die Flüssigkeit injicirt worden war, während in den Versuchen 9 und 10 durchaus gar keine Ligatur in Frage kam.

Von den Kaninchen batten No. 1, 3, 8, 16 und 19 nicht geboren, 5, 9, 10, 11, 17 und 18 hatten geboren, waren aber nicht trächtig; 2, 6 und 20 hatten Junge zur Welt gebracht, und zwar kurz vor den Versuchen: 4 Tage (No. 2), 8 Tage (No. 6) und etwas über 24 Stunden (No. 20). Trächtig waren No. 4, 12, 13 und 15 .

So bald als möglich nach dem Tode oder nach der Tödtung des Thieres ist die Obduction unter Wahrnehmung aller Vorsicht vorgenommen, wobei die bakteriologische Untersuchung, wie aus der Beschreibung der Versuche hervorgeht, gemacht worden ist. Die Geschlechtsorgane wurden herausgenommen, in Formollösung (1:4) während 48 Stunden und dann in Alkohol $\left(95^{\circ}\right)$ gehärtet.

Zwecks mikroskopischer Untersuchung sind ausgeschnittene Theile der Geschlechtsorgane mit absolutem Alkohol, mit Schwefelkohlenstoff 2 mal, mit Schwefelkohlenstoff und Paraffin und zuletzt mit reinem Paraffin behandelt. Die Schnitte sind gewöhnlich mit Hämatoxylin und Eosin oder nach van Gieson gefärbt worden. Zwecks Untersuchung von Bakterien in den Schnitten sind diese nach Gram-Weigert gefärbt worden.

Die photographischen Abbildungen sind im Laboratorium meiner Klinik von Dr. Axel Wallgren und Dr. W. Rosenlew gewonnen. 
des Streptococeus pyogenes ảuf die Schleimhaut der Gebärmutter etc. 295

Die Zeichnungen der Schnitte mit Bakterien sind von mir gemacht. Bevor ich meine Versuche und ihre Resultate vorlege, werde ich eine Beschreibung und einige Abbildungen des mikroskopischen Baues der Scheide, des Gebärmutterhornes, des Eileiters und des Mesometriums des Kaninchen geben.

Scheide. Schleimhaut: Einfaches Cylinderepithel längs der Oberfläche der Schleimhaut, die sich gewöhnlich in höheren oder niedrigeren Falten erhebt. Die Kerne der Zellen sind theils länglich oder rund, schwach gefärbt, theils länger, schmäler, häufig etwas gebogen, stärker gefärbt. Die Kerne befinden sich an der Basis der Zelle. Das Zellenprotoplasma hell gefärbt. Die Zellen des Bindegewebes theils solche mit länglichem, bisweilen nierenförmigen Kern und spärlichem, nach zwei Seiten in lange Fäden ausgezogenen Protoplasma, theils solche mit länglichem, grossen, eiförmigen Kern und sehr spärlichen Protoplasma, sodass eigentlich nur der Kern zu sehen jst. Zwischen diesen Zellen kleine, runde, stärker gefärbte Leukocyten. Blutgefässe mit Capillaren; grosse Lymphräume. Die Schleimhaut grenzt unmittelbar an die Muskelschicht, welche doppelt ist, eine innere, mit im Querschnitt durchschnittenen und eine äussere mit im Längsschnitt durchschnittenen Zellen. Diese beiden Muskelschichten liegen theils dicht aneinander, theils getrennt durch Blut- und Lymphgefässe führende Bindegewebsschichten. Die ätussere Muskelschicht ist mit einer schmalen Schicht Bindegewebe mit Blut- und Lymphgefüssen bekleidet. (Vergl. Taf. IV, Fig. 1).

Die unteren Theile eines jeden der Gebärmutterhörner sind auf einer Strecke von ca. $1 \mathrm{~cm}$ durch Bindegewebe mit einander vereinigt, und münden durch je einen Muttermund in die Scheide. Dieser Theil der Hörner kann Cervix genannt werden und unterscheidet sich von den eigentlichen, von einander getrennten Theilen der Gebärmutter durch die Structur der Schleimhaut. Im unteren Theil der Cervix, also nach der Scheide zu, hat die Mucosa lange, stark verzweigte Falten, die an die Schleimhaut der Tube beim Menschen erinnern. Das oberflächliche Epithel besteht aus dicht aneinander gestellten, länglichen Zellen mit basalem Kern und Cilien. Es finden sich keine Drüsen im eigentlichen Sinne, sondern die drüsenähnlichen Gebilde bestehen aus Einsenkungen der Schleimhaut mit ihrem oberflächlichen Epithel. Die Schleimhaut erinnert an diesen Stellen an die Schleimhaut der 
Scheide: ihr Bindegewebe hat auch Aehnlichkeit mit dem der Scheidenschleimhaut.

Eine Strecke höher hinauf verändert sich die Schleimhaut und wird ähnlich der im übrigen Theile des Hornes befindlichen mit Drüsen.

Die Muskulatur der Cervix besteht, wie das eigentliche Horn, aus zwei Schichten, einer äusseren mit im Querschnitt durchschnittenen und einer inneren mit im Längsschnitt durchschnittenen Zellen, getrennt durch eine dünne Schicht Bindegewebe. Am weitesten nach der Bauchhöhle zu im oberen Theil der Cervix findet sich eine dünne Schicht Bindegewebe. Zwischen jedem der Hörner findet sich eine meistens schmale Bindegewebsschicht. Nach den Seiten zu geht das Mesometrium auf die Cervix über. (Vergl. Taf. IV, Fig. 2).

Gebärmutterhorn. Schleimhaut: Das Bindegewebe ist. von gleicher Struetur wie in der Scheide, aber zellenreicher; die Zellen sind theils länglich mit nach zwei Seiten ausgezogenem Protoplasma, theils mit ovalem oder runden Kern mit spärlichem Protoplasma versehen. Die Zellen sind zahlreicher nach der Oberfläche der Schleimhaut zu. Spärliche Leukocyten. Das Epithel, welches die Oberfläche der Schleimhaut und die in das Lumen ausmündenden Drüsen bekleidet, besteht aus kurzen Cylinderzellen mit grossem, ovalen oder schmäleren Kern und verhältnissmässig spärlichem Protoplasma. Dieses Epithel sondert Schleim in der Weise ab; dass grössere und kleinere amorphe Klumpen vom Zellprotoplasma abgetrennt werden.

Die Muskelschicht ist doppelt. Zwischen jedem der Muskeln findet sich eine gewöhnlich breite, mit Blut- und Lymphgefässen versehene Bindegewebsschicht. Die Muskelschicht ist mit einer äusseren schmalen, an die Bauchhöhle grenzenden Bindegewebsschicht bedeckt. (Vergl. Taf. IV, Fig. 3).

Dàs Mesometrium besteht zu äusserst aus einer dünnen Bindegewebsschicht, unter welcher sich eine Muskelschicht. befindet, die eine Fortsetzung des äusseren Muskels des Gebärmutterhornes bildet. An den Maskel grenzt ein reichlich entwickeltes Fettgewebe und inmitten des Mesometriums verlaufen kleinere und grössere Blutgefässe, die Arterien mit dicken Wänden, Lymphgefässe und grosse Lymphräume. (Vergl. Taf. IV, Fig. 3).

Tube. Die Schleimhaut hat ein oberflächliches, dem im Gebärmutterhorn befindlichen ähnliches, Epithel mit länglichen Zellen, 
welche einen theils länglichen, theils mehr rundlichen, theils schmalen und langen Kern haben. Das Protoplasma ist häufig gegen das Ende gleichsam in schmälere Knospen (Schleim) ausgezogen. Das Bindegewebe hat Aehnlichkeit mit demjenigen des Gebärmutterhornes, die Zellen derselben kommen nach der Oberfläche zu reichlicher, in der Tiefe spärlicher, vor. Keine Drüsen. Die Muscularis ist schmal und besteht aus einer inneren und aus einer äusseren Schicht. Zu äusserst eine sehr dünne Bindegewebsschicht. (Vergl. Taf. IV, Fig. 4).

Mesosalpinx wie Mesometrium.

Weil meine Versuche ${ }^{1}$ ) verschieden ausgeführt und ausgefallen sind, so habe ich dieselben in Gruppen getheilt. Ich beschreibe erst die Versuche der verschiedenen Gruppen nach den über dieselbe geführten Protokollen und gebe dann eine Zusammenstellung der Resultate.

Versuch 1. 13. Juni, Nachm. 7 Uhr. Mittelgrosses junges Kaninchen, das nicht geboren hat. Die Gebärmutter wird herausgenommen. Einschnitt in den oberen Theil der hinteren Scheidenwand. Durch den rechten Huttermund wird $1 / 2 \mathrm{ccm}$ Streptokokken-(Traubenzucker-) Bouillon eingespritzt, nachdem der Katheter $2 \mathrm{~cm}$ weit bineingeführt worden war. Das Gebärmutterhorn wird an der Theilungsstelle (damit die Bouillon nicht in die Scheide hinein getrieben werden soll) unmittelbar, nachdem die Spitze der Bougie durch den Muttermund zurückgegezogen worden war, unterbunden. Die Incisionswunde in der Scheide wird mittels Naht geschlossen. Die Gebärmutter wird in die Bauchhöhle zurückgeführt. Die Bauchwunde wird geschlossen.

Verlauf: Temp. nach der Operation 36,$3 ; 14$. 6. M.-T. 38,7, A.-T. 39,1 ; 15. 6. ‥-T. u. A.-T. 38,8 ; 16. 6. M.-T. 39,6 , A.-T. 36,6 ; 17.6 . M.-T. 37,4 , A.-T. $40 ;$ 18. 6. M.-T. 38,6 , A.-T. 37,6 ; 19. 6. M.-T. 38 , A.-T. 38,9 ; 20. 6. M.-T. 39,7 , A.-T. 39 ; 21. 6. M.-T. 38,6, A.-T. 38; 22. 6. M.-T. 37,5 , A.-T. 37,7; 23. 6. M.-T. 36,4, A.-T. 37; 24. 6. M.-T. 37,8 , A.-T. 37,6 ; 25. 6. M.-T. 36 , A.-T. 35,5 ; 26. 6. М.-T. 35,6, A.-T. 38,2; 27. 6. M.-T. 37, A.-T. 37,1; Tod den 28. Juni Abends. Section: Das Thier stark abgemagert. Von der Bauchwunde ausgehend findet sich ein handflächengrosser, sich nach jeder Seite und nach rückwärts erstreckender subcutaner Abscess. Die Bauchwunde ist nach der Bauchhöhle zu gut geheilt, mit glatter Serosa bedeckt. Keine Verwachsungen zwischen der Bauchnarbe und den Organen der Peritonealhöhle. Die Därme, besonders die Coecumschlinge und das Colon, stark aufgetrieben, dunkel gefärbt, mit dünnflüssigem Inhalt. Die Darmserosa und das Peritoneum parietale überall glatt, glänzend, keine Vermehrung der Bauchflüssigkeit. Neben der Naht in der Scheide ein erbsengrosser Abscess. Das rechte Gebärmutterhorn etwas dicker als das linke. Im

1) Zwei Versuche, 7 u. 14, habe ich als nicht brauchbar(Verunreinigung) weggelassen. 
Cebrigen bieten die Geschlechtheile nichts Abnormes. Die inneren Organe dem Aussehen nach gesumd.

Bakteriologische Untersuchung (Deckglaspräparat und Agar). In der in reichlicher Menge in der Scheide befindlichen dünnflüssigen eiterigen Flüssigkeit finden sich Streptokokken. Im Abscess Streptokokken in Reineultur. In der Flüssigkeit aus der Bauchhöhle keine Bakterien.

Mikroskopische Untersuchung. Das Epithel der Scheidenschleimhaut im Allgemeinen beibehalten, das Bindegewebe unter dem oberflächlichen Epithel reichlich kleinzellig infiltrirt. Im Lumen grössere und kleinere Auhäufungen von poly- und mononucleären Lenkocyten mit spärlichen, schlecht gefärbten Streptokokken.

Das Lumen des nicht injicirten Uterushornes etwas enger als das des injicirten Hornes. In der Schleimhaut, die nach der Oberfiäche zu kleinzellig infiltriert ist, sind die Blutgefässe etwas reicblicher als gewöhnlich entwickelt. In der Schleimhaut des injicirten Gebärmutterhornes sind die Blutgefässe reichlicher und mehr erweitert als normal. Das Epithel an der Oberfiăche und in den Drüsen unverändert, das interglanduläre Bindegewebe gerade wie in normaler Gebärmutter, nur dass dasselbe dicht unter dem oberflächlichen Epitbel kleinzellig infiltrirt ist und eine reichliche Menge kleiner Blutgefässe besitzt. Im Lumen sind einige kleinere Anhäufungen von spärlichen mono- und polynucleären Leukocyten zu sehen.

In keinem der Gebärmutterhörner, weder im Lumen, in der Schleimhaut, in den Lymphgefässen der Muscularis oder an der nach der Bauchhöhle zu gekehrten Fläche, sind Streptokokken zu sehen.

Versuch 5. 14. Juli. Kaninchen, welches den 29. Juni geworfen hat. Laparotomie, Die Gebärmutter wurde durch die Banchwunde herausgenommen. Die Spitze eines durch die Scheide geführten Katheters wurde durch den linken Muttermund in das entsprechende Gebärmutterhorn eingefübrt und $3 \mathrm{ccm}$ Streptokokkenbouillon hineingespritzt. Die Gebärmutter wurde in die Bauchhöhle zurückgeführt, und die Bauchwunde wurde geschlossen, Temperatur zwischen 39 und $40^{\circ}$ vom 14. Juli bis zum 5. August. Später nicht gemessen. Das Thier starb in der Nacht auf den 24. August. Bei der Section am 24. August Vormittags fand man das Thier stark abgemagert. Die Gebärmutterhörner von Pseudomembranen umgeben, das linke Parametrium schwielig, die Bauchwnnde gut geheilt, keine Verwachsungen nach der Bauchhöhle hin. Nichts Bemerkenswerthes in Bezug auf die inneren Organe.

Die bakteriologische Untersuchung der Peritonealflissigkeit und des Inhalts des linken Horns (Agar) gab negatives Resultat. Mikroskopische Untersuchung: Scheide: Schleimhaut und Muscularis normal. Um die Scheide Schwielen, welche aus lockerem Bindegewebe mit spärlich gestellten, theils länglichen Zellen mit rundem Kern und zwei vom Protoplasma ausgehende Fäden, theils solchen mit sternförmig sich verzweigendem Protoplasma bestehen. An gewissen Stellen sieht man Streifen von dicht au einauder gestellten spiudelförmigen Zellen. Die Gefässe sind mit dicken Wänden versehen. Nirgends sind Streptokokken zu sehen. Jedes der Gebärmutterhöruer unverändert; ebenso das Mesometrium. In der Gebärmutterschleimhaut scheinen die länglichen Zellen nach der Oberfläche zu der Zahi nach vermehrt. Kleinzellige Infiltration ist nicht vorhanden. Keine Streptokokken. 
Versuch 6. 18. Juli, Nachm. $3 \frac{1}{2}$ Uhr. Kaninchen, das den 10. Juli 5 Junge geworfen hat. Versuchsordnung wie bei Versuch 5 . In das linke Horn wurde $1 \mathrm{ccm}$ Streptokokkenbouillon (die Streptokokken vom Versuchsthier 4 entnommen) eingespritzt. Verlauf. Temp. vom 18. Juli bis zum 5. August zwischen 39 und $40^{\circ}$. Das Thier starb während des Tages am 13. September. Sektion unmittelbar darauf. Die Bauchwunde gut geheilt, die Narbe mit Mühe zu entdecken. Keine Verwachsungen zwischen den Organen der Bauchhöble und der Bauchwand. Das Thier stark abyemagert. Gebärmutter und Adnexe sehen makroskopisch normal aus; keine Verwachsungen. Von den inneren Organen nichts Bemorkenswerthes.

Die bakteriologische Untersuchung des Inhalts des linken Horus gab ein negatives Resultat. Mikroskopische Untersuchung: Geschlechtstheile normal, nur dass die Schleimhaut in den Gebärmutterhörnern mit einer Menge dilatirter Blutgefässe und spärlicher Drüsen versehen ist (siehe Taf. IX, Fig. 23). Es sind keine Streptokokken zu entdecken.

Versuch 8. 29. August. Kaninchen, das nicht geboren hat. Versuchsanordnung wie bei Versuch 5. In das rechte Gebärmutterhorn wurde $1 \mathrm{ccm}$ Streptokokkenbouillon eingespritzt. Verlauf: Temp. vom 30. August bis zum 14. September etwas über 39. Das Tier starb in der Nacht auf den 8. October. Section den 8. October, Vorm. 11 Uhr. Das Thier mager. Eine tiefe Wunde in der linken Wange (gebissen von anderen Kaninchen).

Die Bauchwunde gut geheilt. Die Serosa glatt, kein Exsudat. Auf der Oberfläche des Herzens dem Aussehen nach eiterige Beläge, die sich leicht ablösen, Herz gross, mit flüssigem dunklem Blut gefüllt. In der Wand des Herzens weissliche Heerde. Gebärmutteroberfläche glatt, anscheinend gesund. Das rechte Horn wie das linke. Bakteriologische Untersuchung: Deckglaspräparate von den Belägen an der Oberfläche des Herzens zeigten keine Mikroorganismen, sondern vorwiegend mononucleäre, spärlich polynucleäre Zellen sowie Endothelzellen mit Vacuolen. Cultur auf Agar vom Belage auf dem Herzen, vom Herzblut und vom rechten Horn steril. Mikroskopische Untersuchung: An den Geschlechtstheilen nichts Bemerkenswerthes. Keine Streptokokken oder andere Bakterien zu sehen.

Versuch 9. 20. September. Ausgewachsenes Kaninchen. Versuchsanordnung wie bei Versuch 5. In das rechte Gebärmutterhorn wurden $2 \mathrm{ccm}$ Streptokokkenbouillon eingespritzt. Verlauf: Temp. vom 20. bis zum 30. September etwa 39. Das Thier lebte mehrere Monate und starb den 19. Januar. Das Thier sehr fett. Keine makroskopischen Veränderungen an den Organen der Bauchhöhle. Gebärmutter makroskopisch unverändert. Bakteriologische Untersuchung des lnhalts des rechten Horns ergab negatives Resultat. Mikroskopische Untersuchung. Geschlechtstheile normal. Keine Bakterien zu sehen.

Versuch 10. 20. September. Grosses Kaninchen. Versuchsanordnung wie bei Versuch 5. In das linke Horn wurden 2 ccm Streptokokkenbouillon eingespritzt. Verlauf: 21. 9. M.-T. 39,2, A.-T. 39,8; 22. 9. M.-T. 41,8, A.-T. 41,4; 23. 9. М.-T. 38,7, A.-T. 39,6. Vom 24.9. bis zum 30.9. war die Temperatur gewöhnlich nahe an 40. Das Thier starb den 30. 11. Section. An der äusseren Seite des Bauches, links 
von der Mittellinie im Niveau mit der Bauchnarbe und etwas böher hinauf eine breite, eiförmige Ausbuchtung von $8 \mathrm{~cm}$ Länge und $4 \mathrm{~cm}$ Breite. Innerhalb dieser Ansbuchtung findet sich Eiter. Der Abscess buchtet auch die innere Fläche der Bauchwand vor, deren Peritoneum jedoch unverletzt ist. Keine Peritonitis. Die Gebärmutter makroskopisch normal. Bakteriologische Untersuchung: Für Cultur auf schrägem Ascitesagar wurde Eiter vom Abscess, Flüssigkeit aus dem linken Gebärmutterhorn und aus der Peritonealhöhle entnommen. Negatives Resultat der Cultur aus Gebärmutter und Bauchhöhle, dagegen geht aus dem Eiter vom Abscess ein kleiner Coccus auf, der nicht Streptococcus ist. Mikroskopische Untersuchung wie bei Versuch 9 .

Versuch 12. 17. November Nachm. 3 Uhr. Kaninchen trächtig in beiden Gebärmutterhörnern, kirschengrosse Fruchtsäcke. Versuchsanordnung wie bei Versuch 5 . In das linke Horn wurden $2 \mathrm{~cm}$ Streptokokkenbouillon eingespritzt, doch scheint das meiste davon in Folge starker Contraction des Hornes in die Scheide hineingepresst worden zu sein. Verlauf: Temperatur 18. 11. M.-T. 38,2, A.-T. 39,1; 19.11. M.-T. 39,4 , A.-T. 39,7 ; 20. 11. M.-T. 40,4, A.-T. 40. Temp. vom 21. bis 30. 11. etwas unter 40. Das Thier starb in der Nacht auf den 7. 12. Allgemeine Kachexie, das Thier in hohem Grade abgemagert. Abscess am linken Oberschenkel. Die Därme scheinen trocken, Mangel an Peritonealflüssigkeit, das Herz auffällig. gross. Die Gebärmutterhörner nicht trächtig, mit etwas injicirten Gefässen (das Thier hat vermuthlich abortirt, ohne dass es bemerkt worden ist). Die Bauchwunde gut geheilt. Keine Verwachsungen oder makroskopische Veränderungen im Bauche. Bakteriologische Untersuchung: Für Cultur auf Agar wurde Peritonealflüssigkeit, Inhalt aus dem linken Gebärmutterhorn, Blut aus Leber und Herz, sowie Eiter vom Abscess genommen. Nur aus dem Abscesseiter ging ein kleiner, kurzer Bacillus auf, aber die übrigen Röhrchen blieben steril. Mikroskopische Untersuchung: Das nicht injicirte Horn normal, nur dass die Schleimhaut etwas gefässreicher ist als gewöhnlich. Nirgends sind Streptokokken zu sehen.

Im Lumen des injicirten Hornes sind Leukocyten relativ spärlich in eine ungefärbte amorphe Mlasse eingebettet zu finden. Die Schleimhaut zeigt spärliche, kurze Drüsen, reichlich Gefässe, beibehaltenes oberflächliches und Drüsenepitbel, kleinzellige Infiltration an der Oberfläche. Nirgends sind Streptokokken zu sehen.

Die oben angeführten 7 Versuche bilden die Gruppe, wo keine Infection mit tödtlichem Ausgang in Folge der in den Uterus injicirten Streptokokkenbonillon eintrat.

Unempfänglich für Infection durch Streptokokken ist das Thier No. 9 gewesen oder es hat dieselbe ohne dadurch bedingten tödtlichen Ausgang überstanden. Dasselbe lebte 4 Monate nach dem Versuche und starb in gutem Ernährungszustande; weder Streptokokken noch andere Bakterien waren nachzuweisen, die Geschlechtstheile waren in jeder Hinsicht normal.

Das Thier No. 6" lebte nahezu 2 Monate und zeigte beim Tode nur starke Abmagerung. Die Geschlechtstheile normal bis auf den 
Umstand, dass die Blutgefässe der Schleimhaut in den Gebärmutterhörnern vermehrt und stark erweitert waren. Es waren keine Streptokokken nachzuweisen. Möglicherweise liessen sich die Vermehrung und die Dilatation der Blutgefässe im Endometrium als eine Folge einer abgelaufenen Reizung des Infectionsstoffes deuten.

In den Versuchen 8, 10 und 12 war der Tod wahrscheinlich durch eine andere Infection verursacht worden; Streptokokken waren nicht nachzuweisen. Das Thier No. 8 lebte über einen Monat und starb abgemagert mit einer tiefen Wunde in der Wange (gebissen von einem anderen Kaninchen). Eitrige Beläge am Herzen, in welchen keine Mikroorganismen nachgewiesen werden konnten. Die Geschlechtsorgane unverändert, ohne nachweisbare Streptokokken. Culturen vom Blute steril.

Das Thier No. 10 lebte 2 Monate, hatte einen Abscess in der Bauchwand, aus dessen Eiter in Cultur ein kleiner Coceus aufging, der, wie sich herausstellte, kein Streptococcus war. Die Geschlechtstheile waren normal und Streptokokken waren nirgends nachzuweisen.

Das Thier No. 12 starb 20 Tage nach dem Versuche, war kachektisch, stark abgemagert, hatte am linken Oberschenkel einen Abscess, in dessen Eiter ein kleiner Bacillus vorgefunden wurde. Die Schleimhaut des injicirten Gebärmutterhornes etwas kleinzellig infiltrirt. Nirgends Streptokokken.

In Versuch 5 starb das Thier nach 1 Monat und 10 Tagen, stark abgemagert, mit Pseudomembranen um die Gebärmutterhörner und Schwielen um die Scheide und in die Parametrien. Die Geschlechtstheile waren im übrigen normal und Streptokokken nirgends mehr zu entdecken. Vermuthlich war eine langsam verlaufende Infection mit obenerwähnten Veränderungen vorhanden.

Das Thier in Versuch 1 starb an Streptokokkeninfection, aber nicht durch Vermittelung der Geschlechtstheile, sondern in Folge von Infection von einem subcutanen handflächengrossen, an der Bauchwand befindlichen Abscess, in welchem Streptokokken nachgewiesen wurden. Ein erbsengrosser Abscess fand sich auch an der Naht in der Scheide, in deren Sekret Streptokokken zu finden waren. Die Schleimhaut der Gebärmutterbörner und der Scheide war kleinzellig infiltrirt, aber in den Geweben waren keine Streptokokken zu sehen.

In diesen Fällen hatten die Thiere demnach den unmittelbaren Einfluss der Infection überwunden, aber die meisten derselben 
starben nachträglich in einem abgemagerten kachektischen Zustard, vermuthlich auf einer durch die Bakterien bez. deren Producte bewirkten langsam verlaufenden Intoxication beruhend. In allen diesen Versuchen, ausser in No. 1, wurde keine Unterbindung des Gebärmutterhornes gemacht, sondern man liess die Bouillon sich frei in dem Horn ausbreiten und durch mögliche Contractionen in die Scheide getrieben werden. Die Continuität der Gebärmutterwand war demnach ungestört. Dieser Umstand ist wohl dem sozusagen negativen Resultat der Versuche zuzuschreiben. Die Schleimhaut der Geschlechtstheile konnte ihre schützende Eigenschaft frei ausüben. In Versuch 12 war das Thier trächtig, überwand aber gleichwohl die unmittelbare Infection.

In folgenden 6 Fällen ist einige Stunden oder Tage nach Anstellung des Versuches eine allgemeine Infection eingetreten.

Die Anordnung der Versuche ist wohl verschieden gewesen, aber weil in allen diesen Fällen eine acute Sepsis und, mit Ausnahme der Versuche 2 und 3, ziemlich übereinstimmende Veränderungen der Uterusschleimhant entstanden sind, habe ich sie in einer Gruppe zusammengestellt.

Versuch 2. 29. Juni, Nachm. 4 Uhr. Kaninchen, das den 25. 6. ein todtes Junges geboren hatte. Versuchsordnung wie bei Versuch 1. In das rechte Gebärmutterhorn wird $1 / 3 \mathrm{ccm}$ Streptokoklenbouillon (Ascitesbonillon: 1/4 Ascites) eingespritzt; das Gebärmutterhorn wurde nicht unterbunden. Verlauf: Temperatur den 29. 6. Abends 37,1. Das Thier starb in der Nacht. Section den 30. 6. Nachm. 3 Uhr. In der Peritonealhöhle blutige Flüssigkeit. Die Serosa der Därme glatt, dieselben nicht aufgetrieben.

Bakteriologische Untersuchung. In der Peritonealflüssigkeit, Deckglaspräparat, spärliche Streptokokken. Im Herzblut, Deckglaspräparat, reichlich Streptokokken. Cultur von Peritonealflüssigkeit und Blut auf schrägem Agar. In den Röhrchen entwickelten sich Streptokokkencolonien.

Mikroskopische Untersuchung. Scheide: Im Lumen sind hier und da Anbäufungen von Streptokokken, solche in kurzen Ketten oder als einzelne Individuen in Ansammlungen von Leukocyten und amorpher Masse zu sehen. Hier und da dem Rande des oberflächlichen Epithels entlang liegen theils dicht an der Zelle, theils bisweilen unter dem äusseren Rande derselben Streptokokken in kurzen Ketten (Taf. VIII, Fig. 1). Wo das oberffächliche Epithel beibehalten ist, sieht man keine Streptokokken unter den Zellen, auch nicht im Bindegewebe, aber an den Stellen, wo sich das Epithel abgelöst hat oder sich durch das Ausfallen von Zellen eine Oeffnung in der Zellenreihe findet, sind Streptokokken unter der losgelösten Zellenreihe oder in Oeffnungen zwischen denZellen zu sehen (Taf. VIII, Fig. 2). Im Allgemeinen sind die Epithelzellen gut beibehalten sowohl hinsichtlich der runden und länglichen Kerne als auch des Protoplasmas, aber an den Stellen, wo Streptokokken 
innerhalb des Epithels oder unter demselben zu finden sind, sind einige Kerne theils von hellerer Farbe, theils gleich wie geschrumpft, während das Protoplasma im unteren Theil der Zelle gleich wie zerfallen ist.

Das Bindegewebe unter dem Epithel ist überall gut beibehalten, nicht kleinzellig infiltrirt. In demselben sind Capillaren und Lymphgefässe zu sehen, von welch' letzteren mehrere mehr oder weniger mit Streptokokken angefüllt sind, welche im Allgemeinen das Gefäss nicht überschreiten, wohl aber: an einigen Stellen in das zunächst umgebende Bindegewebe eingedrungen sind (Taf. VIII, Fig. 3). Auf welchem Wege die Streptokokken aus der Scheide nach diesen Lymphräumen gekommen sind, lässt sich nicht direkt nachweisen, aber in Taf. VIII, Fig. 4 sieht man, wie die Streptokokken in eine Oeffnung zwischer den Epithelzellen, die sich vom Bindegewebe losgelöst hatten, eingedrungen sind, und in dasselbe hineingegangen waren. In der Nähe befindet sich ein mit Streptokokken angefüllter Lymphraum. (Man hat Ursache, anzunehmen, dass die Streptokokken auf dem erwähnten Wege in den Lymphraum gelangt sind und sich hier vermehrt haben.)

Im Lymphraume in dem die Muscularis umgebenden Bindegewebe sind an mehreren Stellen reichlich Streptokokken zu sehen, die sich gleichfalls in den Bindegswebsspalten, nicht aber in den kleinen oder in den grösseren Blutgefüssen finden (Taf. VIII, Fig. 5). Einzelne Individuen sind in das Gewebe zwischen den Bindegewebszellen eingedrungen, aber eine kleinzellige Infiltration ist nicht vorhanden. kokken.

In einigen Lymphgefässen der Muskelschicht finden sich Strepto-

Das injicirte Gebärmutterhorn. Wie Taf. VIII, Fig. 6, zeigt, besteht die Muscularis aus zwei Schichten, einer inneren dickeren und einer äusseren schmäleren, getrennt durch eine ausserordentlich breite, mit Blut- und Lymphgefässen versehene Bindegewebsschicht. In mehreren dieser letzteren sind reichlich Streptokokken zu sehen, meistens an der Wand haftend, aber auch in Klümpchen im Lumen; einige Bacterien sind in das zunächst liegende Bindegewebe hinausgetreten. In der äusseren Muskelschicht, dicht unter der äusseren Bindegewebsschicht, sind zwischen den Muskelzellen Streptokokken za sehen. Die äussere dünne Bindegewebeschicht nach der Bauchböhle zu ist mit Streptokokken reichlich infiltrirt (siehe Taf. VIII, Fig. 6), stellenweise verdickt (neugebildetes Bindegewebe) und an anderen Stellen mit einer amorphen Masse mit darin eingebetteten Lenkocyten (Exsudat) bedeckt, in welcher reichlich Streptokokken zu sehen sind.

Das oberflächliche Epithel der Schleimhaut ist im Allgemeinen beibehalten, aber stellenweise sich lösend. Hier und da im Lumen längs dem Rande der Schleimhaut sind Anhäufungen von amorpher Masse mit Leukoeyten und Streptokokken zu sehen, welche doch nirgends in oder zwischen die Zellen des oberflächlichen Epithels hineingedrungen sind, selbst nicht, wo sie an der Oberfläche derselben entlang liegen. Auch an den Stellen, wo sich das oberflächliche Epithel abgelöst bat und das Bindegewebe blossgelegt ist, sind Streptokokken nur ganz obertlächlich in diesem zu sehen, nicht tiefer hinein (siehe Taf. VIII, Fig. 7). An keiner Stelle bemerkt man Streptokokken innerhalb der Drüsen. In gleicher Weise wie in der Scheide liegen sie in der Gebärmutter längs der Oberfïche der Schleimhaut bez. des Epithels derselben, ist aber ein Defect im oberflächlichen Epithel vorhanden, so dringen sie zwischen. 
die Zellen ein (Taf. VIII, Fig. 8). In am Mesometrium haftenden Eiter finden sich Streptokokken.

In dem nicht injicirten Gebärmutterhorn verhält es sich ebenso wie in dem injicirten. Auch hier finden sich im Lumen kleine Anhäufungen von Eiterkörperchen und Streptokokken. Keine Bakterien sind in den Lymphräumen der Schleimhaut zu finden, wohl aber in den grossen Lymphräumen, die sich zwischen jeder der Muskelschichten sowie in und an der änsseren Bindegewebsschicht befinden.

An der Stelle, wo die Oeffnung in der Scheide mittels Nähte vereinigt ist, sind in den Eitermassen um die Fäden herum eine Menge Streptokokken zu sehen.

Versuch 3. 29. Juni, Nachmittags 4,30 Uhr. Junges Kaninchen, das nie geboren hat. Versuchsanordnung wie heim vorhergehenden Versuch 2. Streptokokken-Aseitesbouilon $1 / 2$ eem. Nacht.

Verlauf: Temp. 29. Juni Abends 37,2. Das Thier starb in der

Section deu 30. Juni, Nachm. 3,30 Uhr. Die Peritonealhöhle von gleicbem Aussehen wie bei dem Thier No. 2.

Bakteriologische Untersuchung: Ausgeführt wie im Versuch 2, giebt ein analoges Resultat.

Mikroskopische Untersuchung. Scheide: In den Lymphgefässen. im Bindegewebe, welches die eigentliche Scheidenwand umgiebt, sind Streptokokken zu sehen, aber auch im Bindegewebe selbst finden sich hier und da Bakterien. Die Blutgefässe sind im Allgemeinen frei von Bakterien, aber Taf. VIII, Fig. 9 zeigt ein kleines Blutgefäss, mit Streptokokken gefüllt, während andere in der Nähe befindliche Blutgefässe frei sind. In der Nähe des mit Bakterien gefüllten Gefässes sieht man im Bindegewebe zerstreute Streptokokken. In der äusseren Muskelschicht sieht man an einer Stelle eine Streptokokkenkette zwischen den Muskelzellen liegen (Taf. VIII, Fig. 10). Blut- oder Lymphgefässe sind nicht in der Nähe zu seben. Das Bindegewebe der Schleimhaut besteht aus spärlichen Zellen und ist nicht kleinzellig infiltrirt. Hier und da in den Lymphgefässen und dicht unter dem Epithel, wo sich dieses stellenweise von dem darunter liegenden Bindegewebe gelöst hat, sieht man Streptokokken angehäuft. Einzelne oder kleine Colonien Streptokokken finden sich im Lumen längs dem Epithel, dicht an diesem. Aber auch an Stellen, wo das Epithel erhalten scheint, sind Streptokokken unter demselben und im äussern Theil der Zellen $2 u$ sehen (Taf. VIII, Fig. 11). An einigen Stellen sind Streptokokken in das Bindegewebe hinein, zwischen das Epithel und ein nahe der Oberfläche gelegenes, reichlich mit Bakterien gefülltes Lymphgefäss vorgedrungen (Taf. VIII, Fig. 12). An diesen Stellen ist eine Lücke zwischen den Epithelzellen vorhanden und die Kerne derselben sind eingeschrumpft, länglich schmal, nicht so gross und ruud wie unter normalen Verhältnissen.

Auch wo das Epithel erhalten scheint, kann man an einigen Stellen eine kurze Streptokokkenkette zwischen dem Epithel und einem dicht daneben mit Bakterien gefüllten Lymphraum sehen. An einer Stelle sieht man eine kurze Streptokokkenkette im Bindegewebe, eine lange Strecke entfernt vom Epithel und den mit Bakterien gefüllten Lymphräumen liegen.

In der Cervix ist die Schleimhaut unverändert. In der Muscularis 
sind keine Streptokokken zu sehen, wohl aber in den Lymphräumen des Bindegewebes ausserhalb derselben. In den Blutgefässen sind keine Bakterien zu sehen. In den Lymphräumen in dem Bindegewebe, das zwischen jedem der Gebärmutterhörner liegt, sind Bakterien zu sehen.

Das injicirte Gebärmutterhorn. Die Schleimhaut gut beibehalten, das oberfächliche Epithel und die Zëllen der Drüsen in der Regel an ihrem Platz. Das Bindegewebe nicbt kleinzellig infiltrirt. Im Lumen einige spärliche kleine Anhäufungen von Leukocyten mit Streptokokken oder nur Anhäufungen von Bakterien. Hier und da sieht man eine kurze Streptok̉okkenkette längs dem oberflächlichen Epithel. An einigen Stellen hat sich das oberflächliche Epithel gelöst, und hier sind einige Streptokokkenketten an der Oberfläche des entblössten darunterliegenden Bindegewebes zu sehen (Taf. VIII, Fig. 13). An dem schmalen äusseren Bindegewebe entlang sind Streptokokken zu finden; solche sind auch in das Gewebe selbst eingedrungen.

Das nicht injicirte Gebärmutterhorn. Im Lumen kleinere Anhäufungen von Leukocyten und vereinzelte Streptokokken längs dem Rande des oberflächlichen Epithels, das überall gut beibehalten, nicht im Loslösen begriffen ist. Weder im interglandulären Gewebe noch in den Drüsen sind Streptokokken zu sehen.

In der äusseren Bindegewelosschicht, theils am Rande entlang, theils tiefer in das Gewebe hinein Gruppen und einzelne Ketten von Streptokokken.

In den Blut- und Lymphgefässen des Mesometriums sind keine Streptokokken zu sehen, woh] aber hier und da im Bindegewebe, in kleinen Lymphgefässen oder in den Bindegewebsspalten. Längs der Oberfläche des Mesometriums, an der Peritonealhöhle finden sich Streptokokken, welche auch in das Bindegewebe eingedrungen sind.

In der Mesosalpinx finden sich Streptokokken in der äusseren schmalen Bindegewebsschicht, welche den am Rande entlang rerlaufenden Muskel überzieht, in diesem sowie in dem tiefer liegenden Bindegewebe-stellenweise in Massen. In den Blutgefässen sind keine Bak terien zu sehen.

Die Zellen in der Schleimhaut der Tube sind Iänglich mit eckigem Kern und Cilien, kleine runde Schleimklümpchen absondernd. Nirgends sind Anhäufungen von Leukocyten zu sehen. Streptokokken nur in einzelnen Ketten am oberflächlichen Epithel liegend.

Neben den Fimbrien der Tube ist der Sachverhalt folgender. Streptokokken an mehreren Stellen zwischen den Fimbrien und in einzelnen Ketten am oberflächlichen Epithel derselben. Wo dieses abgestosseri ist, finden sich Streptokokken am darunterliegenden entblössten Bindegewebe entlang, aber Bakterien sind auch zwischen den Zellen des Epithels zu sehen, wo diese sich gelöst haben oder ganz unbedeutend von einander stehen. Auch an einigen Stellen unter den wie es scheint beibehaltenen Zellen sind Streptokokken bemerkbar. Diese halten sich nur im oberflächlichsten Theil des Bindegewebes, sie sind noch nicht dazu gekommen, in die Lymphgefässe desselben einzudringen. Ist das Epithel in zusammenhängenden Strecken gut beibebalten, so versperren die Zellen den Bakterien den Weg, welche sich dann nur an der Oberfläche der Zellen entlang, an den Cilien hängend, finden. An den Stellen, wo sich Streptokokken zwischen oder unter den Zellen des Oberflächenepithels finden, scheinen diese letzteren weniger gut gefärbt und beibehalten. Eine Leukocytenauswanderung in grösserer Menge 
hat noch nicht stattfinden können. An einer Stelle sieht man, wie am Ende einer Fimbrie das Bindegewebe mit Leuköcyten mit pyknotischem Kerm besetzt ist und wie Streptokokken sich zerstreut im Bindegewebe um diese herum nnd im Oberflächenepithel zwischen den Zellen desselben finden. In Gefässen mit deutlichem Endothel sind keine Bakterien zu sehen, aber an einer Stelle sieht man in einem grossen Lymphgefäss eine Anbäufung von Streptokokken. Die Streptokokken finden sich in bedeutend reichlicherer Menge um und im abdominalen Ende der Tube als im übrigen Theil.

Versuch 4. 11. Juli. Kaninchen, das den 4. 7. 8 Junge geworfen hatte. Laparotomie 12 Uhr Nachm. Gebärmutter schwanger, erbsengrosse Fruchtsücke ziemlich entfernt von der Theilungsstelle der Hörner. Die Gebärmutter wurde durch di€ Bauchwunde herausgezogen. Die Spitze eines durch die Scheide geführten Katheters wurde durch den linken Muttermund eingepasst und eine Strecke in das entsprechende Gebärmutterhorn hineingeführt. $1 \mathrm{ccm}$ Streptokokkenbouillon (Traubenzuckerbouillon) wurde in das linke Horn hineingespritzt. Die Gebärmutter wurde in die Bauchhöhle zurückgeführt. Die Bauchwunde wurde geschlossen.

Verlanf: Temp. nach der Operation 37; 12. 7. H.-T. 40,1, A.-T. 40; 13. 7. M.-T. 38,8, A.-T. 38,9; 14. 7. Y.-T. 33,8. Das Thier starb Morgens um 8 Uhr. Section: 14. 7. Nachm. 4 Uhr. Peritonitis seropurulenta, leicht abzulösende Pseudomembranen. Die Gebärmutterhörner stark angeschwollen, mit gelblichen, eiterigen Belägen bedeckt. Das linke Gebärmutterhorn stärker angeschwollen als das rechte. Die Milz geschwollen.

Bakteriologische Untersuchung: In der Peritonealfiüssigkeit, Deckglaspräparat, reichlich Streptokokken. Kultur auf schrägem Agar von Blut (aus Herz und Leber) sowie von.Peritonealflüssigkeit: reichliche Entwickelung von Streptokokken.

Mikroskopische Untersuchung. Das injicirte Horn. Der obere Theil der Cervix. Die Masse, welche das Lumen füllt, besteht hauptsächlich aus poly- und mononucleären Leukocyten mit schwach gefärbtem Kern oder in kleine Körnchen zerfallenden; Streptokokken in Diploform oder in längeren Ketten, theils frei, theils in Leukocyten; losgerissenen Theilen des oberflächlichen Epithels der Schleimhaut, gewöhulichen Zellen in Reiben neben einander, mit theils vorwiegend schwach gefärbtem, gleichsam schrumpfenden oder in gröbere Körnchen zerfallenden Kerne, theils in geringerem Grade intensiv gefärbten, gut erhalteuen grossen Kernen. In diesen Kernen bez. Zellen sind keine Streptokokken zu sehen.

Das oberflächliche Epithel ist theils beibehalten, das unterliegende Bindegewebe bedeckend, jedoch einen breiteren $Z$ wischenraum als in normaler Cervix freilassend, theils auf einer lüngeren oder kürzeren Strecke losgelöst. Die Zelikerne sind zum Theil stark gefärbt, von normaler ovaler Form, theils klein, gleich wie schrumpfend, aber doch gut tingirt. Mehrere Zellen sind sehr kurz mit länglichem Kern, theils schwach gefärbt, gleich wie im Absterben begriffen. Hier und da sieht man eine Zelle, die eine Anhäufung von Kernen in Form einer Weintraube') oder in einer Reibe enthält, und an mehreren Stellen

1) Vgl. Kossmann, Studien zur normalen und pathologischen Anatomie der Placenta. Dieses Archiv. Bd. 57 1898. H. 1. S. 224. 
zwischen den Zellen polynucleäre Leukocyten mit pyknotischen Kernveränderungen, welche die angrenzenden Epithelzellen bei Seite schieben (Taf. VIII, Fig. 14). Derartige Leukocyten mit pyknotischen Kernveränderungen sing auch unter dem Epithel, zwischen den Drüsenzellen, im Drüsenlumen und im Bindegewebe zu sehen. (Vergl. Taf. VIII, Figg. 15 und 16).

Wo das oberflächliche Epithel sich gelöst hat und das Bindegewebe bloss liegt, oder wo das oberflächliche Epithel schwach gefärbt ist, sieht man, dass Streptokokken in das Bindegewebe, jedoch stets in den aberflächlichen Theil desselben eingedrungen sind. (Taf. IX, Fig. 17).

Die oberflächlich nahe dem Lumen gelegenen Drüsenschläucbe sind auffallend erweitert und mit theils ungefärbter, theils gefärbter amorpher Masse und Leukocyten gefüllt. An der Mündung der Drüse sind Streptokokken zu sehen, aber in der Regel nicht tiefer hinein in die Drüse; doch sieht man hier und da gegen den Boden zu eine Streptokokkenkette. Niemals sieht man Streptokokken im Bindegewebe um die Drüse an den Stellen, wo das Drüsenepithel beibebalten ist. In den tiefer in die Schleimhaut hinein gehenden quer abgeschnittenen Drüsen sieht man im Lumen eine kleinere Menge Inhalt, die Zellen der Drüse liegen dicht am Bindegewebe. Kernhaufen sieht man in den näher der Oberfläche der Schleimhaut gelegenen Drüsenzellen, nicht aber in den tiefer hinein ragenden.

Die Blutgefässe in der Schleimhaut sind im allgemeinen erweitert und reichlich vorhanden. In den Blut- und Lymphgefüssen sind keine Streptokokken zu. sehen.

Jede der Muskelschichten ist normal. Im Muskelgewebe selbst, in den innerhalb desselben befindlichen Blut- und Lymphgefässen sind keine Streptokokken zu sehen, wohl aber in und längs der nach der Peritonealhöhle zu gelegenen Bindegewebeschicht, in den feinen Membranen, welche von dieser ausgehen, sowie in den Eiteransammlungen, die an der Oberfläche haften. (Taf. V, Fig. 5 zeigt den oberen Theil der Cervix mit dem noch vereinigten Hörneru, von dem das rechte inficirt ist).

Das injicirte Gebärmutterhorn oberhalb der Cervix. Nach der Oberfläche der äusseren Bindegewebsschicht zu, sowie in daran haftenden Eiteransammlungen finden sich reichliche Streptokokken. Die Muskelschichten sind gut beibehalten, ohne Bacterien. Die Schleimhaut verhällt sich der Hauptsache nach wie im cervicalen Theil des Gebärmutterhornes. Das oberflachliche Epithel ist stellenweise auf langen Strecken abgestossen, und in dem das Lumen füllenden Eiter zu finden. Das beibehaltene oberflächliche Epithel ist stellenweise schwach gefärbt mit Haufen von kleinen Kernen in der Zelle und häufig niedrig, wie Taf. IX, Fig. 18 zeigt. An den Stellen, wo sich das oberflächliche Epithel abgelöst hat, sind Streptokokken in der Oberfläche des Bindegewebes und gleichfalls etwas tiefer in dasselbe binein zu sehen. Eine reichliche Menge Leukocyten, mehrere mit pyknotischen Kernen findet sich in dem oberfiächlichen Theil des Bindegewebes und auf demselben.

Stellenweise sind die in das Lumen mündenden Drüsen am Grunde gut erhalten, aber nach der Mündung zu in der Art verändert, dass die Zellen theils verschwunden, theils schwach gefärbt sind mit in mehrere kleine Stücke zerfallenden Kernen. Gleichwohl finden sich ziemlich gut erhaltene Zellen mit Kernhaufen. Das Lumen der Drüse ist mit Streptokokken und reichlich Leukocyten mit pyknotischen Kernen gefüllt. 
An den Stellen, wo die Drüsenzellen verschwunden oder schwach gefärbt sind, sieh $\hbar$ man Streptokokken in der Oberfläche des blossliegenden Bindegewebes oder unter den Zellen. Die tiefer in die Drüse hinein ragenden Zellen sind gut erhalten und unterhalb denselben sind keine Bacterien zu sehen. Leukocyten mit pyknotischen Kernen finden sich auch zwischen den Drüsenzellen. (Vergl. Taf. VIII, Fig. 16).

Auch in den oberflächlich in der Schleimhaut befindlichen Drüsen, welche quer durchschnitten worden sind, sodass die Mündung nicht wahrzunehmen ist, findet sich Eiter mit Streptokoklzen. Einige Drüsen sind enorm erweitert und mit Eiter und Streptokokken gefülit. Man sieht auch Drüsen, deren Zellen zerstört oder nur als Fragmente in dem mit Leukocyten gefüllten Lumen befindlich sind. (Siehe Taf. IX, Fig. 19). In den in der Näbe von diesen befindlichen Capillaren sind keine Bacterien zu sehen.

In den erweiterten Blutgefässen bez. Capillaren und Lymphräumen der Schleimhaut sind keine Streptokokken zi sehen, auch tiefer hinein in das Bindegewebe derselben finden sich keine Bacterien.

Höher hinauf in dem injicirten Horn (vergl. Taf. V, Fig. 6) ist das oberflächliche Epithel der Schleimhant zum. grössten Theil verschwunden und die Zellen in dem Theill der Drüsen, welcher näher der Oberfläche der Schleimhaut gelegen ist, theils verschwunden, theils schwach gefärbt, gleich wie absterbend. Die Oberfläche des Bindegewebes der Schleimhaut ist mit Leukocyten infiltrirt (Taf. IX. Fig. 20). Die Blutgefässe sind sehr erweitert. Die Drüsen, speciell die mehr oberflächlichen, sind mit Eiter gefüllt. Stellenweise sieht man Leukocyten und Streptokokken zwischen den degenerirten Drüsenzellen und dem umgebenden Bindegewebe, tiefer in dasselbe hinein, im Lumen der Drüse (vergl. Taf. VIII, Fig. 16 und Taf. IX, Fig. 21).

Nirgends sieht man Streptokokken in den Bindegewebszellen oder in den Drüsenzellen, wohl aber in Leukocyten, die nicht gefärbt sind, nicht in denjenigen mit deutlichem Kern. Die Leukocyten, welche durch das Drüsenepithel, zwischen die Zellen, dringen, haben häufig: pyknotische, gut gefärbte Kerue, aber wenn sie zum Drüsenlumen gelangt sind, sind sie schwach gefärbt oder haben gar keine Farbe aufgenommen (vergl. Taf. VIII, Fig. 16). An einigen Stellen, wo das Drüsenepithel schwach gefärbt ist, sieht man die Streptokokken zwischen die Zellen vordringen. Taf. IX, Fig. 22 zeigt Haufen von mononucleären Leukocyten unter dem oberflächlichen Epithel.

Das Uteruskorn zwischen den Fruchtsäcken gleichartig verändert. Die Fruchtsäcke nicht untersucht, scheinen aber eine eitrige Flüssigkeif zu enthaiten. Nahe dem Anfang der Tube finden sich im Lumen des Gebärmutterhorns spärliche Anhäufungen von amorpher Masse und Leukocyten mit darin eingemischten Streptokokken. Theils in Haufen, theils in einzelnen Ketten finden sich Streptokokken hier und da an der Oberfläche des Oberfiächenepithels entlang, aber nicht unter demselben, auch nicht tiefer hinein im Lumen der Drüsen.

Das nicht injicirte Gebärmutterhorn (Taf. V, Fig. 7). Reichliche Entwicklung ron Drüsen in der gefalteten Schleimhant. Die Kerne der Zellen gut gefärbt. In den meisten der Zellen des oberflächlichen Epithels sowie in den Zellen im unteren Theile der Drüsen Kernbanfen. Das Lumen des Horns frei bis auf einige einzelne Streptokokkenhaufen in Resten von Leukocyten, gleichwohl in so geringer Menge, dass ein Einfluss, auf die. Schleimhaut nicht eingetreten ist 
Nirgends in der Wand des Gebärmutterhornes, ausser in der oberflächlichen, nach der Peritonealhöhle zu gelegenen Bindegewebsschicht, sind Streptokokken zu finden.

Im Mesometrium enorm erweiterte, mit rothen Blutkörperchen gefüllte Venen mit äusserst dünner, aus Endothel bestehender Wand. Hier und dort sind unter denselben einige kleine Streptokokkenhaufen zu sehen, Ausserdem kleine Arterien, mit dicker Wand, ohne Streptokokken. In den Lymphgefässen in der Nähe der Blutgefässe finden sich reichlich Bakterien. Ebenso an der gegen die Peritonealhöhle gerichteten Oberfläche des Mesometriums.

Die Tube der injicirten Seite näher dem Gebärmutterhorn: Im Lumen spärlich Leukocyten und Schleim, hier und da eine kurze Streptokokkenkette. Das Oberflächenepithel, das Bindegewebe der Schleimhaut, die Muscularis obne Streptokokken. Solche finden sich dagegen reichlich in der äusseren. Bindegewebeschicht, in deren Lymphgefässen und ibrem oberflächlichen Theil, sowie in an dieser Bindegewebsschicht haftendem Eiter, In den Blutgefässen sind keine Bakterien zu sehen.

Am Rande der Mesosalpinx und in ihren Lymphgefässen finden sich Streptokokken.

Die Tube weiter vom Gebärmutterborn: In spärlichem Eiter im Lumen hier und da eine kurze Streptokokkenkette. Uebrigens übereinstimmend mit den Verhältnissen in der Tube näber dem Gebärmutterhorn.

Der obere Theil der Scheide (Taf. VI, Fig. 8): Im Lumen, besonders des linken Theils, Anhäufungen von schwach gefärbten Leukocyten and Streptokokken. Hier und da losgerissene Epithelzellen, auch reihenweise angeordnete. Das oberfachliche Epithel meistentheils beibehalten. An vielen Stellen sieht man. Streptokokken, dicht an den Zellen und in dem oberflächlichen Theil des Protoplasmas der Zelle. Nirgendwo finden sich Streptokokken unter den Zellen, im Bindegewebe oder in den Blut- bez. Lymphgefässen der Schleimhaut. Leukocyten traten auf zwischen den Epithelzellen, aber die Schleimbaut ist nicht besonders kleinzellig infiltrirt.

Versuch 11. 17. Novbr, Nachm. 3 Uhr, Kaninchen, das früher geboren hat. Streptokokkenbouillon, $2 \mathrm{ccm}$, wird in das rechte Gebär. mutterborn eingespritzt, das darauf nach abwärts unterbunden wird.

Verlauf. 17.11. A.-T. 38,1; 18.11. M.-T. 38,4. Das Thier starb in der Nacht auf den 19.11. Section 19.11. Darmserosa glatt. Injection in einigen der Darmschlingen, welche etwas succulent waren. Vermehrung der lackfarbigen Bauchflüssigkeit. Leichte Verwachsungen zwischen der Bauchwand bei der Narbe und der Blase sowie dem vorderen Theile des Cervix. Die Gebärmutterhörner adbärent am Lig. latum (Mesometrium) und nach hinten am Dickdarm. Das Horn oberhalb der Unterbindung dilatirt. Die Bauchnarbe von gewöhnlichem Aussehen. Lunge, Herz und Leber makroskopisch gesund.

Bakteriologische Untersuchung. Deckglaspräparat von Peritonealfüssigkeit zeigt abgestossene Endothelzellen, spärliche, vollständig zerstörte Leukocyten, Streptokokken, vorwiegend Diplokokken oder in kurzen Ketten. Blnt vom Herzen und Peritonealtlüssigkeit wurde auf gewöhnlichen Agar geimpft. Im Röhrchen mit Peritonealflüssigkeit entwickelten sich vorwiegend Streptokokken und spärliche Colonien von Bacterium coli (wahrscheinlich post mortem auftretend; die Section 
wurde spät gemacht). Im Röhrchen mit Blut entwickelten sich spärlich Streptokokkencolonien.

Mikroskopische Untersuchung: Scheide normal; Cervix uteri weiter hinunter uach der Scheide zu: Die äussere Muskelschicht besteht aus zerstreuten, durch breite Bindegewebsbalken getrennten Muskelbündeln, die innerere besteht aus mehr zusammenhängenden Bündeln. In dem Bindegewebe, das sich zwischen jedem der Hörner befindet, sieht man grosse Gefässe: Venen, kleinere solche: Arterien und Lymphgefässe. In der Schleimbaut ist das oberfächliche Epithe] beibehalten, mit Cilien und deutlichen gleichförmigen basalen Kernen. Im Lumen sind keine Streptokokken zu sehen, auch nicht längs dem oberflächlichen Epithel, aber an einigen Stellen finden sich hier und da Streptokokken im Bindegewebe und in kleinen Lymphgefässen in demselben. In den grossen Venen und Lymphgefässen, die sich im pericervicalen Bindegewebe zwischen den Hörnern befinden, sind reichlich Streptokokken zu finden, sowohl im Lumen der Gefässe (Venen), als auch noch mehr längs der Wand sowie im Bindegewebe in der näcbsten Umgebung des Gefässes. Man sieht auch grosse mit Streptokokken gefüllte Räume umgeben von Bindegewebe, in welchem reichlich Bakterien zu sehen sind. Ebenso sind in den Lymphgefässen und in den Venen im Bindegewebe und zwischen jeder der Muskelschichten Streptokokken zu sehen, welche an einigen Stellen in das umgebende Bindegewebe ausgetreten sind.

Cervix böher hinauf(vergl. Taf. VI, Fig.9): Das Lumen des einen, linken, Hornes ist nicht mit Eiter gefüllt. Die Schleimhaut ist auffallend schmal an der antimesometralen Seite und dicker nach der mesometralen Seite zu. Das rechte Horn ist mit Eiter gefüllt, die Dicke der Schleimhaut gleichermaassen wie im linken Horn. Im linken Horn ist die Schleimhaut ziemlich normal, das oberfächliche Epithel and das Epithel in den Drüsen ist gut beibehalten. Das Bindegewebe ist bei Weitem nicht so reichlich kleinzellig infiltrirt, wie in der Schleimhaut des rechten Hornes.

In dem Eiter, der das Lumen des rechten Hornes füllt, sind nicht färbbare Streptokokken zu sehen. Das oberflächliche Epithel der Schleimhaut] theils' grösstentheils, erhalten, theils losgelöst, so dass das Bindegewebe glatt liegt. Die Zellen sind stellenweise nicht mehr in Reihen, sondern theils gleichwie aufeinander gethürmt, theils spärlich stehend. Stellenweise hat das Protoplasma keinen so gleichmässigen Rand mehr wie normal, sondern ist gleichwie schrumpfend oder zerfallend mit angenagtem Rande (siehe Taf.IX, Fig. 24). Die Drüsen sind spärlich, kurz. Die Epithelzellen derselben sind an mehreren Stellen geschrumpft, in Reihen verschmolzen oder vom Bindegewebe 'gelöst unter Zurücklassung einer Lücke. Zwischen den Drüsenzellen sind an mehreren Stellen Eiterkörperchen mit pyknotischen Kernen zu sehen. Das Bindegewebe ist im Allgemeinen normal, nur dass es gegen die Oberfiäche zu reichlich kleinzellig infiltrirt ist, mehrere Leukocyten mit pyknotischen Kernen. An einzelnen Stellen sind Streptokokken in oder an der Schleimhant $z u$ sehen; doch sieht man an einzelnen Stellen, wie Venen und Lymphgefässe mit Streptokokken gefüllt sind, die sich auch im umgebenden Bindegewebe neben dem oberflächlichen Epithel und zwischen den Zellen finden (vergl. Taf. IX, Fig. 25). Diese Figur zeigt das oberflächliche Epithel längs einer Strecke der Schleimhant zerstört, Leukocyten, dicht gehäuft, am Bindegewebe, welches kleinzellig in- 
filtrirt ist; nach den Seiten zu ist ein Rest des oberflächlichen Epithels und zwei kleine Drüsen zu sehen.

In dem Bindegewebe, das sich um die und zwischen den Muskelschichten, zwisehen jedem der Hörner und im Fettgewebe des Mesometriums findet, sind in darin befindlichen Venen und Lymphgefässen, sowie in dem diese umgebenden Gewebe zahlreiche Streptokokken zu sehen. Längs der Oberfläche des Mesometriums finden sich Bakterienhäufen (Taf. VI, Fig. 10 zeigt eine schwache Vergrösserung des injicirten Horns oberhalb der Theilungsstelle der Hörner).

Das injicirte Horn unterhalb der Unterbindung: Die antimesometrale Schleimhaut ist schmal, die mesometrale ist breiter und gefässreicher. Die Drüsen spärlich, kurz. Eiter im Lumen, das in geringerem Grade erweitert ist. Das Bindegewebe der Schleimhant reichlich kleinzellig infiltrirt. Im Fiter im Lumen sind keine Streptokokken zu sehen. An einigen zerstreuten Stellen sind im Mesometrium sowie in den Venen und Lymphgefässen des Bindegewebes zwischen den Muskelschichten Streptokokken zu sehen. Bakterien sind in der Schleimhaut nicht zu sehen.

Das injicirte Horn oberhalb der Unterbindung: Die Wand des Hornes sehr dünn, jede der Muskelschichten beibehalten, aber sehr schmal. Die Schleimhaut äusserst dünn, stellenweise nur aus einer schmalen Schicht Bindegewebe mit spindelförmigen Zellen und spärlichen, schmalen und flachen Drüsen bestehend. Kleinzellige Infiltration nach der Oberfläche zu. Das oberflächliche Epithel theils beibehalten, theils abgestossen, theils sind die Zellen von einander gerissen. Die Zellen sind meistentheils nicht so hoch wie normal, isondern niedrig, gleich wie abgeplattet; in einigen sieht man keinen Kern, sondern die ganze Zelle ist ein feinkörniges, langgestrecktes Gebilde. (Taf. IX, Fig. $26 \mathrm{a}, \mathrm{b}$, c zeigt die düme Schleimhaut in verschiedener Weise verändert.) An einer Stelle ist im Lumen eine Strecke von der Schleimhaut ein langgestreckter Streptokokkenbaufen zu sehen. An einzelnen Stellen bemerkt man in den Lymphgefässen im Bindegewebe zwisehen den Muskelschichten Streptokokken.

In den Lymphgefässen und Venen des Mesometriums sowie in dem diese umgebenden Bindegewebe und im Fettgewebe sind Streptokoklen zu sehen.

Das nicht injicirte linke Gebärmutterhorn. Die äussere Bindegewebsschicht, sowie jede der Muskelschichten unverändert. Die Schleimhaut auffallend arm an Drüsen, welche kurz sind und sich nur durch den oberflächlichen Theil der Schleimhaut erstrecken. Das oberflächliche Epithel gut beibehalten, vom Protoplasma der Zellen gehen kurze Verlängerungen (Schleim) aus. Das Bindegewebe normal, nicht kleinzellig infiltrirt, auch nicht reichlicher vascularisirt als gewöhnlich. Die antimesometrale Schleimhaut ist auffallend schmal mit spärlichen Drüsen. Im Lumen des Hornes sind spärliche Haufen von Leukocyten zu sehen und zwischen diesen einige Streptokokken. Auch sind hier und da längs dem oberfächlichen Epithel einige Streptokokken als Diplokokken oder in kurzen Ketten zu sehen, nirgends aber in, unter oder zwischen den Zellen des oberflächlichen Epithels, auch nicht irgendwo in der Schleimhaut oder in den Lymphgefässen des Hornes.

In den Lymphgefässen und Bindegewebespalten des Mesometriums sowie in der nächsten Umgebung derselben sind in den Venen reichlich Streptokokken. dagegen spärlich Bacterien zu sehen. Längs dem Rande 
des Mesometriums finden sich in den daran haftenden Eiteransammlungen reichlich Streptokokken. An einigen Stellen sind Streptokokken in der äusscren Bindegewebeschicht des Gebärmutterhornes und an einigen Stellen reichlich in eine amorphe Masse resp. Leukocyten dicht nach der Oberfläche derselben zu eingeschlossen.

Die Tube des injicirten Horns: Streptokokken kommen reichlich in den Lymphgefässen und Lymphspalten der äusseren Bindegewebsschicht vor, aber nicht im Lumen der Tube, auch nicht in ihrer Schleimhaut vor. Streptokokken sind spärlich am Epithel der Fimbrien zu finden, aber nicht unter demselben, auch nicht im Bindegewebe derselben.

In den Lymphgefässen der Mesosalpinx, in ihrem Fettgewebe, im Bindegewebe zwischen den Muskelbündeln sowie in der züsseren Bindegewebsschicht finden sich an einjgen Stellen reichlich Streptokokken.

In den Versuchen 13 und $15 \mathrm{kam}$ eine Symbiose des Streptococcus pyogenes und einer stäbchenförmigen Bakterie vor. Wahrscheinlich wurde dieser Bacillus während der Versuche von der Scheide nach dem Uterus gebracht. In beiden Thieren entstand eine allgemeine Sepsis.

Versuch 13. 18. Nov. Nachm. $1 \frac{1}{2}$ Ubr. Kaninchen trächtig in jeder der Gebärmutterhörner; kirschengrosse Fruchtsäcke. In das linke Horn wurden, nach Anlage eines seidenen Fadens um das Gebärmutterhorn nahe am Cervix und Zuziehung desselben um den Katheter, $3 \mathrm{ccm}$ Streptokokkenbouillon eingespritzt, worauf der Faden angezogen wurde, sodass vermuthlich die Flüssigkeit nicht in die Scheide gelangte.

Verlauf. 18. Nov. A. T. 38,$2 ; 19$. Nov. M. T. 38,8, A. T. 39; 20. Nov. M. T. 39,1, A. T. 39,$7 ; 21$. Nov. M. T. A. T. 39,$8 ; 22$. Nov. M. T. 39,4 , A. T. 38,2 ; 23. Nov. M. T. 37,4, A. T. 37,2 . Das Thier starb in der Nacht auf den 24. Nov, Sektion den 2t. Nov. Vorm. Die Bauchwande gut geheilt. In der Bauchhöhle spärlich blutiges Exsudat. Einige Dünndarmschlingen aufgetrieben. Verwachsungen zwischen Bauchwand und Cervix uteri, sowie zwischen der Blase und Cervix uteri. Die Oberfläcbe des Herzens mit weisslichen, dünnen Membranen belegt. In der Pericardialhöhle blutige Flüssigkeit. Im linken Gebärmutterhorn dünnflüssiger Eiter, im rechten Horn spärliche, blutige Flüssigkeit. Die Gebärmutterhörner aufgetrieben, fingerdick, die Wand blutig imbibirt.

Bacteriologische Untersuchung. Deckglaspräparat von der Peritonealflüssigkeit von dem oberen Theil der Bauchböhle zeigt Endothelzellen und spärlich Leukocyten, aber keine Bacterien. Das Deckglaspräparat vom Eiter aus dem Gebärmutterhorn zeigt reichlich Leukocyten nebst zahlreichen Streptokokken. Für Cultur auf Agar wurden Peritonealflüssigkeit, Herzbelag, Herzblut, Eiter aus dem linken und Inhalt aus dem rechten Gebärmutterhorn genommen. Aus dem Herzblut entwickelten sich in Reincultur reichlich Streptokokken. Aus der Peritonealftïssigkeit keine Streptokokken, aber spärlich ein anderer Coccus (wahrseheinlich eine Verunreinigung, derselbe befindet sich nicht im Blute aus dem Herzen). Aus dem Inhalt im rechten Uterushorn entwickelten sich einzelne, aus dem Eiter im linken Horn dagegen reichliche Streptokokkenkolonien. 
Mikroskopische Untersuchung. Scheide. Längs dem oberflächlichen Epithel sieht man theils Anhäufungen von stäbchenförmigen Bacterien, theils einzelne solche. An einer Stelle sind sie in die Schleimhaut eingedrungen, gerade unter dem oberflächlichen Epithel, das an dieser Stelle weniger distinkt gefärbt ist und einige Zellen sind gleich wie im Zerfall. Sonst ist das oberflächliche Epithel gut beibehalten. Das Bindegewebe normal, nicht kleinzellig infiltrirt. Streptokokken und Stäbchen finden sich längs dem äusseren Rande der Scheide, in an dieser haftendem, amorphem Belag, sowie hier und da im äussersten Theil des Gewebes. In der Muscularis oder den übrigen Theilen der Wand ist nicht jede Art der Bacterien zu sehen.

Cervix. Das nicht injicirte Horn. Die Schleimhaut gut beibehalten, das Lumen frei. Das Lumen des injicirten Hornes erweitert, gefüllt mit einer amorphen Masse mit Leukocyten, an deren Rande man gefürbte, knrze, dicke Stäbchen in reichlicher Menge sieht; in der Masse selbst finden sich einzelne derartige Bacterien. Unter diesen Stäbchen sind spärlich Streptokokken zu sehen. In den gewöhnlich polynuclearen Leulkocyten, die sich längs der Schleimhaut finden, sind Streptokokken zu sehen. Längs dem oberfächlichen Epithel sieht man hier und da diese Stäbchen (Taf. IX, Fig. 27), sowie an einigen Stellen im äusseren Theile des Protoplasmas der Zelle. An einzelnen Stellen sind Streptokokken unter dem beibehaltenen oberflächlichen Epithel zu seheu. (Taf. IX, Fig. 28). In den übrigen Theilen der Schleimhaut oder in anderen Theilen des Hornes sind keine Bacterien zu sehen. Auch im Mesometrium sind solche nicht zu finden.

Das injicirte Horn ist stellenweise erweitert (Fruchtsäcke) bis 15 resp. $10 \mathrm{~mm}$ Breite (auf gehärtetem Präparat). Es besteht aus einer sehr düunen Wand mit 2 schmalen Muskelschichten mit sehr schmaler Zone Bindegewebe zwischen denselben, sodass sie stellenweise unmittelbar an einander liegen, dünner Schicht äusseren Bindegewebes und schmaler Schleimhaut, mit dünnem Bindegewebe, oberflächlichem Epithel und spärlichen Drüsen. An mehreren Stellen ist eine lange Strecke der Schleimhaut ohne Drüsen und besteht nur aus oberflächlichem Epithel und Bindegewebe mit reichlich Gefässen. Die Zellen des oberflächlichen Epithels sind kurz oder abgeplattet, häufig proliferirend, sodass sie im Schnitt dicht an einander liegen; mehrere Zellen mit mehreren Kernen. Die kleinen Blutgefässe sind reichlich mit rothen und weissen Blutkörperchen gefüllt, letztere theils mono- theils polynucleär, theils mit pylnnotischen Kernen. Das Epithel der Drüsen beibehalten. An mehreren Stellen sieht man zwischen den Drüsenzellen Leukocyten mit pyknotischen Kermen. An einigen Stellen der Schleimhaut finden sich ungefärbte Leukocyten und eine amorphe Masse mit reichlich Streptokokken in Klumpen dicht an der Schleimhaut, die an dieser Stelle ihr oberflächliches Epithel verloren hat und reichlich mit Eiterkörperchen, von denen mehrere pyknotisch sind, mit zerfallenden Kernen infiltrirt ist. In der Oberfäche der Schleimhaut sieht man an diesen Stellen Streptokokken in geringer Menge. In den Schnitten, wo die Placenta getroffen ist, sieht man Streptokokken in derselben. Vom Embryo ist nichts zu sehen.

Streptokokken sind in einigen der Lymphyefässe des Mesometriums zu sehen, wie auch in einigen Lymphgefässen im Bindegewebe zwischen den Muskelschichten.

Das injicirte Horn an den Stellen, wo dasselbe nicht stark er- 
weitert ist (zwischen den Fruchtsäcken) (vergl. Taf. VII, Fig. 11). Im Allgemeinen stimmt die Schleimhaut mit der vorstehend geschilderten überein; doch ist sie stellenweise dicker mit längeren Drüsen, die selbst hier spärlich sind. Im Lumen findet sich an manchen Stellen Eiter mit Streptokokken, theils in, theils neben den ungefärbten Leukocyten. An einigen Stellen finden sich Streptokokken eine Strecke in das Bindegewebe hinein. An den Stellen, wo das oberflächliche Epithel fehlt oder als Rest mit schlecht gefärbtem Kern und zerfallendem Protoplasma stehen geblieben ist, findet sich eine grössere Menge Eiter mit Streptokokken dicht am Bindegewebe, dessen oberflächlicher Theil kleinzellig infiltrirt ist (wie zuvor geschildert und in Taf. IX, Fig. 29 abgebildet). An anderen Stellen ist das oberflächliche Epithel platt gedrückt, schmal oder reichlich entwickelt mit mehreren Kernen in jeder Zelle. Taf. IX, Fig. 30 zeigt, wie an einer. Stelle, wo die Zellen des oberflächlichen Epithels sich voneinander entfernt haben, schlecht gefärbt (degenerirt) sind und einige derselben schrumpfende Kerne haben, Streptokokken zwischen die Zellen vordringen, ohne doch tiefer in das Bindegewebe hinein zu gehen. Taf. IX, Fig. 31 zeigt eine Stelle, wo die Streptokokken tiefer in das Bindegewebe hineingedrungen sind.

Bei ziemlich gut erhaltenem Epithel sind die Streptokokken längs der Oberfläche desselben gelagert, ist dasselbe aber auf einer kurzen Strecke unterbrochen oder degenerirt, so sind im Bindegewebe, in oder unter diesen Zellen Streptokokken zu sehen. Leukocyten wie pyknotische Kerne sind zwischen den Zellen des oberflächlichen Epithels zu sehen. Nirgendwo finden sich Streptokokken in den oberflächlichen Blutgefässen der Schleimhaut. An einigen Stellen an der äusseren Bindegewebeschicht des Hornes ist eine einzelne Streptokokkenkette zu sehen, kommt aber in den Muskelschichten oder im Bindegewebe zwischen denselben nicht vor.

Am Ende des Gebärmutterhornes, gerade am Anfang der Tube, finden sich stäbchenförmige Bakterien ziemlich reichlich in amorpher Masse im Lumen und in den Drüsengängen.

Die Tube enthält im Lumen stäbchenförmige Bacillen in Anhäufungen einer normalen Masse (Schleim). Leukocyten finden sich nicht im Lumen. Ebenso sieht man derartige Bakterien spärlich längs der äusseren Bindegewebsschicht, dagegen nicht in der Schleimhaut. Die Mesosalpinx ist frei von Bakterien.

Um die Fimbrien herum finden sich keine Bakterien, weder im Lumen noch neben dem oberflächlichen Epithel. Mesosalpinx ist von Bakterien frei.

Versuch 15. 18. Nov., Nachm. 3 Uhr. Kaninchen, trächtig, kirschengrosse Fruchtsäcke. In das rechte Horn wurden $2^{1 / 2} \mathrm{ccm}$ Streptokokkenbouillon wach Anbringung und Zuziehung einer Seidenligatur eingespritzt. Die Flüssigkeit drang in den nächsten Fruchtsack ein, der deutlich angesehwellt wurde. Nach Herausziehen des Katheters wurde die Ligatur vollständig zugezogen.

Verlauf: 18. Nov. A. T. 36,$6 ;$ 19. Nov. M. T. 36,$8 ;$ A. T. 34. Das Thier starb in der Nacht auf den 20. Nov.

Section den 20. Nov. Vorm. Die Banchwunde geheilt, von gutem Aussehen. Die Därme aufgetrieben, miteinander und mit den Gebärmutterhörnern resp. den Fruchtsäcken zusammengelötet, welche auch untereinander dureh weissliche, leicht abzulösende Membrane verlötet 
sind. Hämorrhagische Peritonitis in der ganzen Bauchhöhle, blutige Flüssigkeit.

Bakteriologische Untersuchung: In Deckglaspräparaten von der Peritonealflüssigkeit sind keine Zellen, aber in ziemlich reichlicher Venge ein kurzes dickes Stäbchen, sowie zahlreiche Streptokokken, Diplokokken, längere und kürzere Ketten zu sehen. Für Kultur wurde Peritonealflüssigkeit (in Agar) und Blut aus dem Herzen (in Bouillon) genommen. In den Agarröhrchen entwickelten sich Streptokokken und eine dem Bacterium coli äbnliche Bakterie. Im Herzblut Streptokokken in Reincultur.

Mikroskopische Untersuchung. Scheide: Die Schleimhaut stark kleinzellig infiltrirt, mit erweiterten Blutgefässen. Stäbchenförmige Bakterien, ähnlich denen in Versuch 13, theils in spärlichen Ansammlungen von Leukocyten und amorpher Masse im Lumen nahe dem oberflächlichen Epithel, theils längs dem oberflächlichen Epithel, theils im äusseren Theil der Zellen, theils an einigen Stellen im unteren Theil derselben sowie unter denselben. An mehreren. Stellen hat sich das oberflächliche Epithel in einer zusammenhängenden Kette von Zellen losgelöst. Unter diesem und im äusseren Theil des darunterliegenden, reichlich kleinzellig infiltrirten Bindegewebes sieht man recht viele derartige stäbchenförmige Bakterien. Die verschiedenen Theile der losgelösten Epithelzellen weniger distinkt zu unterscheiden als gewöhnlich. An einigen Stellen fehlen oberfïchliche Epithelzellen, daselbst sind die Stäbchen in das Bindegewebe hineingedrungen.

Cervix tiefer hinunter (nach der Scheide zu). Die Schleimhaut im Allgemeinen beibehalten, das Bindegewebe etwas kleinzellig infiltrirt. Das oberflächliche Epithel beibehalten. Stäbchenförmige Bakterien theils auf den Zellen des oberflächlichen Epithels, theils zwischen den Falten der Schleimhaut. Hier und da haben sich die Zellen gelöst und in den äussersten Theilen des Bindegewebes sind Stäbchen zu sehen. Im Cervix höher hinauf sind die Zellen des oberflächlichen Epithels theils erhalten, theils losgelöst. Theils längs der Oberfläehe, theils im oberflächlichen Theil des Bindegewebes sind stäbchenförmige Bakterien und Streptokokken zu sehen. In den Blut- und Lymphgefässen innerhalb der Scbleimhaut sowie in der Ungebung. derselben finden sich stäbchenförmige Bakterien. An mehreren Stellen ist die Schleimhaut gleichsam überschwemmt von diesen Stäbchen, welche dicht aneinander im Bindegewebe liegen. In den Drüsen, speciell in den tiefer gelegenen, sind die Epithelzellen vom Bindegewebe losgerissen und, unter Zurücklassung eines ziemlich breiten $Z_{\text {wischenraumes, nach dem Bindegewebe }}$ zusammengeballt. Die Kerne der Zellen sind distinkt gefärbt, das Protoplasma aber in hohem Grade zu einer schmalen Zone um den Kern reducirt. Zwischen den Zellen der Drüse, im Lumen, im Zwischenraum, sowie im umgebenden Bindegewebe sind zahlreiche Stäbchen zu sehen. An andern Stellen ist das Drüsenepithel längs dem Bindegewebe zusammenhängend, aber die Kerne in den meisten Zellen vermehrt (wie dies bei Trächtigkeit der Fall ist), mehrere kleine Kerne in jeder Zelle bildend. Das Zellprotoplasma ist schwach gefärbt, körnig. Auch an dieseu Stellen sind unter den Zellen Stäbchen zu sehen. Innerhalb der Muscularis cervicis sieht man keine Bakterien, aber in den grösseren Lymphräumen im Bindegewebe zwischen jeder der Muskelschichten sind, wenngleich spärlich, Stäbchen zu sehen. In den grossen Lymphge- 
fässen in dem den Cervix umgebenden Bindegewebe sind gleichfalls Stäbchen zu sehen.

Im trächtigen Horn bemerkt man überall in der Placenta reichlich Stäbchen.

Zwischen den Fruchtsäcken tiefer hinunter im Horn finden sich im Eiter im Lumen sowohl Streptokokken als auch Stäbchen. Stäbchen in der Schleimhaut angeordnet wie höher hinauf im Cervix, obwohl nicht in so reichlicher Menge; sie überschwemmen nicht in gleich hohem Grade das Bindegewebe, sondern befinden sich meistens im Drüsenlumen and längs dem oberflächlichen Epithel, welches gerade wie das Drüsenepithel verhältnissmässig gut beibehalten ist. Stäbchen sind an einigen Stellen in Lymphgefässen in der Nähe der Drüsen sowie in den Drüsenräumen zwischen den Drüsenzellen und dem umgebenden Bindegewebe zu sehen. Das Bindegewebe ist gerade nicht kleinzellig infiltrirt. An einigen Stellen sieht man in der Schleimhaut Streptokokken. Am äusseren Rande des Gebärmutterhornes, theils längs, theils und noch mehr innerhalb des äusseren Theiles des Bindegewebes sowohl Stäbchen als auch Streptokokken, an mehreren Stellen in dichten Haufen. Im Hesometrium des trächtigen injicirten Hornes sind in den Lymphgefässen Stäbchen zu sehen.

In den Versuchen 2, 3, 4, 11, 13 und 15 sind die Thiere an acuter Sepsis gestorben. Der Befund bei der Section und die Resultate der mikroskopischen Untersuchung sind doch in den verschiedenen Fällen verschieden gewesen.

In den Versuchen 2 und 3 war das Verhältniss durchaus übereinstimmend. Jedes der Tiere starb einige Stunden nach dem Versuch an acuter Sepsis mit beginnender Peritonitis. Streptokokken wurden im Blute, in der Peritonealflüssigkeit, in dem Gebärmutter- und Scheideninhalt gefunden. In den Lymphgefässen der Scheide und den Gebärmutterhörnern, in dem die Scheide umschliessenden Bindegewebe, in und auf der äusseren Bindegewebeschicht der Gebärmutterhörner wurden reichlich Bacterien gefunden. Die Infection des Organismus war sehr rasch vor sich gegangen, die Streptokokken waren wahrscheinlich durch die Wunde in der Scheide, aber vielleicht auch durch die Schleimhaut der Geschlechtstheile in die Bauchhöhle eingedrungen. Eine kleinzellige Infiltration in dieser letzteren hatte noch nicht zur Entstehung gelangen können; in der Scheide und in dem Gebärmutterhorn fanden sich nur spärlich Eiterkörperchen. Das oberflächliche Epithel war nur theilweise in Degeneration, theilweise war es speciell in der Scheide, aber auch im injicirten Gebärmutterhorn abgelöst und gestattete daher das Eindringen der Bacterien.

In Versuch 11 traf man bereits etwas über 24 Stunden nach der Einspritzung der Streptokokken in das Gebärmutterhorn auf 
acute Infection und Peritonitis mit leichten Adhärenzbildungen zwischen Bauchwand, Harnblase und dem vorderen Theile der Cervix uteri. Die Gebärmutterhörner waren bereits mit Mesometrium und dem Dickdarm adhärent. Streptokokken wurden im Blute, in der Peritonealflüssigkeit und wenngleich spärlich im Eiter im injizirten Horn und auch als vereinzelte in spärlichen Eiteranhäufungen im nicht injicirten Horn gefunden. Innerhalb der Cervix ist das oberflächliche Epithel der Schleimhaut beibehalten und im Lumen sind keine Streptokokken zu sehen, aber in den kleinen Lymphgefässen der Schleimhaut und hie und da im Bindegewebe derselben sind Streptokokken zu sehen, welche reichlich in Venen und Lymphgefässen im pericervicalen Bindegewebe, sowie im Bindegewebe zwischen den Hörnern und auch innerhalb des Bindegewebes um diese Gefässe herum vorkommen. Auch in Lymphgefässen und Venen im Bindegewebe zwischen jeder der Muskelschichten, sowie in der nächsten Umgebung derselben finden sich Streptokokken. Höher hinauf in der Cervix im injicirten Theile ist das oberflächliche Epithel degenerirt (siehe Näheres in der Boschreibung des Versuches), der oberflächliche Theil des Bindegewebes kleinzellig infiltrirt. Streptokokken finden sich in und neben diesem, sowie in Venen und Lymphgefässen und dem dieselben umgebenden Bindegewebe. In Venen und Lymphgefässen zwischen den und um die Muskelschichten zwischen jedem der Hörner und in dem dieselben umgebenden Bindegewebe finden sich zahlreiche Bacterien.

Das Gebärmutterhorn selbst ist in geringerem Maasse angegriffen. Die Schleimhaut ist reichlich kleinzellig infiltrirt, aber frei von. Streptokokken, die in Venen und Lymphgefässen zwischen den Muskelschichten und in der äusseren Bindegewebeschicht zu finden sind. Im Lumen nur spärlich Streptokokken. Das oberflächliche Epithel verändert wie aus der Beschreibung und Fig. 25 Taf. IX ersichtlich. In Venen und Lymphgefässen des Mesometriums und in dem dieselben umgebenden Bindegewebe sind Streptokokken zu finden.

Scheide und das nicht injicirte Horn nahezu normal.

In diesem Falle hat sich die Infection hauptsächlich geltend gemacht in dem cervicalen Theil des injicirten Gebärmutterhornes und ist wahrscheinlich davon ausgegangen. Der Verlauf ist ein rascher gewesen, sodass grosse Veränderungen in der Gebärmutterschleimhaut nicht zur Ausbildung gelangt sind, wie sich auch Streptokokken im Uteruslumen recht spärlich, dagegen reichlich 
jn Venen und Lymphgefässen der Wand und des Mesometriums fanden.

In Versuch 4 lebte das Thier 3 Tage. Es starb an acuter Sepsis mit sero-purulenter Peritonitis und reichlich Eiter in dem injicirten Horn. Streptokokken wurden im Blute, in der Peritonealflüssigkeit und im Eiter im Gebärmutterhorn gefunden. An den Stellen, wo das oberflächliche Epithel der Gebärmutterschleimhaut oder das Drüsenepithel zerstört ist, sind im darunter liegenden Bindegewebe Streptokokken zu finden, dieselben sind aber nirgends in den Lymphgefässen des Gebärmutterhornes zu sehen, sondern nur in und an der äusseren Bindegewebeschicht, in den Venen und Lymphgefässen des Mesometriums und im nächsten umgebenden Bindegewebe. Die Blutgefässe in der Schleimhaut sind reichlich vorhanden und dilatirt. Das nicht injicirte Horn ist nahezu normal. Streptokokken sind nur an der äusseren Bindegewebeschicht desselben zu finden.

In den Versuchen 2 und 3 muss man, wie bereits erwähnt, annehmen, dass die rasche Infection mit tödtlichem Ausgang auf der technischen Ausführung der Experimente beruhte, da die Streptokokkenbouillon durch die geöffnete hintere Scheidenwand injicirt wurde: Die Oeffnung wurde freilich unmittelbar darauf mit Naht vereinigt, aber diese war nicht hinreichend schützend gegen die bakterielle Invasion in die Bauchhöhle und die Entstehung der rasch verlaufenden allgemeinen Infection. Ausserdem wurde keine Unterbindung des injicirten Hornes gemacht, soudern die Bouillon konnte aus dem Gebärmutterhorn in die Scheide hinunter getrieben werden. Indessen entstanden in jedem der Fälle durch die Einwirkung der Bakterien gewisse Veränderungen des Oberflächenepithels der Scheide und der Gebärmutter.

Eine rasch verlaufende Allgemeininfection war auch in Versuch 11 vorhanden. In diesem Falle wurde das Gebärmutterhorn unterhalb der.Stelle, wo die Injection gemacht wurde, unterbunden. Gleichwohl waren die durch die Streptokokken zu Wege gebrachten Veränderungen am meisten ausgeprägt in der Cervix uteri unterhalb der Unterbindung. Wahrscheinlich ging die Infection von diesem Theil des Genitalcanals aus, begünstigt durch den Umstand, dass das Horn oberhalb unterbunden war und demnach an einer wenn auch circumscripten Stelle nicht mehr anatomisch normal war.

In Versuch 4, wo keine Unterbindung gemacht worden war und wo die Wand des Gebärmutter- und Scheidenrohres in ihrer 
Continuität nicht gestört war, entstand auch eine Infection, aber keine so rasch verlaufende wie in Versuch 11, sondern den Tod erst nach 3 Tagen bewirkende. Merkwürdig genug waren die Lymphgefässe der Scheiden- und Gebärmutterwand nicht, wenigstens nicht sichtbar, mit Streptokokken gefült, welche in der Bauchhöhle und im Lumen der Gebärmutter und der Scheide wohl vorhanden waren. Auf welchem Wege die Streptokokken in die Bauchhöhle gedrungen sind, ist nicht mit Bestimmtheit zu ermitteln, wahrscheinlich aber doch durch die Wand des Gebärmutterhornes, bezw. längs den Lymphgefässen derselben. Gegen eine Annahme, dass die Streptokokken durch die Tube nach der Bauchhöhle gekommen sein sollten, spricht ausser dem Umstande, dass die Tuben gerade wie die Gebärmutterhörner bei Kaninchen ungewöhnlich lang sind, der Umstand, dass in Versuch 11, wo das Thier 24 Stunden nach der Injection in die Gebärmutter, die nicht gravid war, starb, Streptokokken im Lumen der Tube oder in deren Schleimhaut nicht zu finden waren, wohl aber an ihrer äusseren nach der Bauchhöhle gerichteten Oberfläche. In Versuch 4 fanden sich freilich im Lumen der Tube einzelne Streptokokken, aber die Schleimhaut war unverändert; dagegen waren auch in diesem Versuch reichlich Bakterien an der äusseren Oberfläche der Tube zu sehen. Das Thier lebte zwei Tage und die Streptokokken hätten wohl in retrograder Richtung aus der Bauchhöhle in die Tube gelangen können.

In Versuch 4 zeigt die Gebärmutterschleimhaut zumeist das Bild einer septischen Endometritis. Zu bemerken ist, dass das Thier in beginnender Sehwangerschaft war, ein Umstand, weleher den Einfluss der Streptokokken wohl begünstigte und die normale Widerstandsfähigkeit der Gebärmutter verringerte.

In den Versuchen 13 und 15, wo die Thiere mit kirschengrossen Fruchtsäcken trächtig waren und $51 / 2$ bezw. etwas über 1 Tag nach Einspritzung der Streptokokken an acuter Sepsis und Peritonitis mit blutigem Exsudat starben, war eine Mischinfection vorhanden. Aus dem Blute beider Thiere wurden Streptokokken gezüchtet, aus der Peritonealflüssigkeit von Thier No. 13 wurde ein Coccus gezüchtet, der nicht im Blute aus dem Herzen zu finden war, aber vom Thier No. 15 eine kurze stäbchenförmige Bakterie und Streptokokken.

In Fall 13, wo das Thier erst nach $5^{1 / 2}$ Tagen starb, waren die Gebärmutterhörner fingerdick, im injicirten wurde Eiter mit 
stäbchenförmigen Bakterien und Streptokokken in reichlicher Menge gefunden, das rechte enthielt eine spärliche blutige Flüssigkeit mit geringer Menge Streptokokken. Stäbchenförmige Bakterien fanden sich in der Scheide längs dem im allgemeinen gut beibehaltenen oberflächlichen Epithel desselben, sowie untermischt mit Streptokokken längs dem äusseren Rande der Seheide. In der Cervix an der injicirten Seite fand sich Eiter mit reichlich Stäbehen und spärlich Streptokokken, welche an einigen Stellen unter dem oberflächlichen Epithel zu sehen waren. Im injicirten Horn wurde Eiter mit Streptokokken gefunden, die auch in dem oberflächlichen Theil des Bindegewebes der Schleimhaut, wo das oberfiächliche Epithel verloren gegangen war, zu finden waren. Ebenso fanden sich Streptokokken in der Placenta, in den Lymphgefässen des Mesenteriums, in den Lymphgefässen im Bindegewebe zwischen den Muskelschichten und an der äusseren Bindegewebsschicht als einzelne Ketten.

In Fall 15 fanden sich ähnliche stäbchenförmige Bakterien im Eiter in der Scheide und im oberflächlichen kleinzellig infiltrirten Theile des Bindegewebes der Sehleimbaut, wo das oberflächliche Epithel verloren gegangen war. In gleicher Weise verhielt es sich im weiter hinunter nach der Scheide zu liegenden Theil der Cervix, wo sich im oberen Theil derselben längs der Oberfläche der Schleimhaut und im oberflächlichen Theile derselben sowohl Stäbchen als auch Streptokokken fanden. In den Blut- und Lymphgefässen der Schleimhaut und im Bindegewebe um dieselben herum fanden sich Stäbchen, die auch innerhalb der Drüsen, zwischen den Zellen derselben und im umgebenden Bindegewebe, sowic in den Lymphräumen in dem Bindegewebe, das sich zwischen den Muskelschichten sowie um die Cervix findet, zu sehen waren. In dem injicirten Horn höher hinauf zwischen den Fruchtsäcken wurden im Eiter im Lumen sowohl Streptokokken als auch Stäbchen gefunden, diese letzteren aber auch in der Schleimhaut wie im oberen Theil der Cervix, in der Placenta, in den Lymphgefässen des Mesenteriums und untermischt mit Streptokokken theils längs, theils in der oberflächlichen Bindegewebsschicht.

Nach dem Befunde in beiden Versuchen scheinen die stäbchenförmigen Bakterien mehr zerstörend gewirkt zu haben und leichter in das Endometrium eingedrungen zu sein als die Streptokokken.

Beide Thiere waren trächtige; die Injection hat sich wahr- 
scheinlich in Folge dieses Umstandes schnell und kräftig geltend gemacht.

Folgender Versuch zejgt die beginnende Wirksamkeit der Streptokokken im Uterushorn.

Versuch 16. 11. Octbr. Vorm. 10 Uhr. Kaninchen, das nicht geboren hat. In das linke Gebärmutterhorn wurde $1 / 2 \mathrm{ccm}$ Streptokokkenbouillon eingespritzt. Unterbindung unterhalb der Stelle der lnjection. Temp. 11. 10. Abends 37,5. Das Thier starb in der Nacht auf den 12. 10. Section den 12. 10.; 10 Uhr Vorm. Das Peritoneum iiberall glatt, glänzend, nur stellenweise an den Därmen kleine Flecke. Die Därme nicht aufgetrieben. Unbedeutende Gefässinjection am Dünndarm. Die Peritonealfeuchtigkeit nicht in erheblichem Grade vermehrt. Eine Dünndarmsehlinge zunächst dem Operationsfelde etwas aufgetrieben und stärker injieirt als die übrigen Dünndärme; an derselben ist eine kleinere serổse Blutung vorhanden. Um die Wunde herum unter dem Peritoneum kleine Sugillationen und eine kleinere Blutung. Zwischen Gebärmutter und Umgebungen keine Verwachsungen. Jedes der Gebärmutterbörner etwas geschwollen, das rechte vorwiegend. Das rechte Horn schlingernd, adhärent an sich selbst. Kleine Blutungen an der Oberfläche. In der Scheide eine kleinere Menge dünnflüssiger Flüssigkeit.

Bakteriologische Untersuehung. Präparat aus Flöckchen vom Perineum zeigt Epithelzellen, mono- und polyuucleäre Leukocyten, aber keine Bakterien, aus der Bauchfeuchtigkeit und anderen Stellen ziemlich reichlich polynucleäre Zellen, aber keine Bakterien. Culturen von Peritonealflüssigkeit aus der Nähe der Bauchwunde sowie aus der Gegend um die Gebärmutter absolut steril. Das Gleiche ist der Fall mit Culturen aus Herz und Leber. Der Inhalt aus dem rechten Gebärmutterhorn steril, der aus dem linken Horn zeigt ziemlich reichlich Streptokokken (in Cultur), Leukocyten und spärlich Streptokokken im Deckglaspräparat.

Mikroskopische Untersuchung. Scheide normal. Das nicht injicirte Gebärmutterhorn normal. Spärlich Drüsen und Bindegewebszellen Keine kleinzellige Infiltration. Das injicirte Gebärmutterhorn gerade oberhalb der Ligatur etwas erweitert. Jede der Muskelschichten sehr schmal. Das Lumen verhältnissmässig gross, die Schleimhant sehr schmal, ausgenommen an der mesometralen Seite, wo sie etwas dicker ist, etwa wie in dem nicht injicirten Horn. Das aberfiächliche Epithel beibehalten: die Drüsen sehr vereinzelt und kurz. Im schmalen Theile der Schleimhaut bilden die Drüsen ausscbliesslich kurze Krypten. Das Bindegewebe reichlich kleinzellig infiltrirt. Nahe der Oberfäche kleine Anhäufungen vou Eiter: mononucleäre und polynucleäre Leukocyten, Streptokokken in kurzen Ketten. Keine Streptokokken sind in der Schleimbaut zu sehen, auch nicht längs dem oberflächlichen Epitbel, das überall beibehalten ist. Aus den Zellen des oberflächlichen Epithels sondert sich Schleim in Klümpehen ab. Man sieht Leukocyten zwischen den Zellen vordringen. Längs dem äusseren Rande des Hornes liegen Leukocyten, aber keine Streptokokken.

Weiter aufwärts von der Ligatur sind die Muskelschichten schmal, aber die Schleimhaut dicker als in den vorstehend beschriebenen Präparaten, ähnlich der in dem nicht injicirten Horne. Nach der Oberfläche zu ist die Schleimhaut etwas kleinzellig infiltrirt. Auch hier 


\section{Heinricius, Experimentelle Untersuchungen über die Einwirkung}

findet sich nahe der Oberfläche spärlicher Fiter und einige Streptokokken.

Unterhalb der unterbundenen Stelle ist die Schleimhaut normal dick mit spärlichen Drüsen, nicht kleinzellig infiltrirt. Streptokokken sind nicht zu sehen. Die unterbundene Stelle wie die vorstehenden. Die Schleimhaut verhältnissmässig dick. In Eiterhäufchen um die Ligatur herum sind Streptokokken zu sehen, aber nicht in der Schleimhaut.

In diesem Versuch lebte das Thier nicht ganz 24 Stunden nach dem Versuch und starb unter Symptomen von Collaps. Eine allgemeine Sepsis hatte sich noch nicht ausbilden können; im Blute und in der Peritonealflüssigkeit fanden sich keine Streptokokken. Der Inhalt im rechten Gebärmutterhorn war steril, aber in dem injicirten, linken Horn wurden Streptokokken gefunden. Oberhalb der unterbundenen Stelle war das injicirte Horn bereits durch in demselben sich ansammehdes Sekret dilatirt. Das Bindegewebe der Schleimhaut war kleinzellig infiltrirt und an der Oberfläche desselben fanden sich Streptokokken und ausgewanderte Leukocyten; man sieht solche sich durch die Zellen des noch beibehaltenen Oberflächenepithels vordrängen.

In diesem Falle würde sich vielleicht eine allgemeine Sepsis ausgebildet haben, wenn das Thier nicht so früh gestorben wäre: vielleicht hätte es auch die Wirkung des Infectionsstoffes überwinden können. Ob der Tod durch Infection oder durch einen anderen Umstand verursacht wurde, konnte ich nicht ermitteln.

In folgenden 3 Versuchen wurde vor und nach der Infection einer geringeren Menge Streptokokkenbouillon $(1,10,0,10$ bezw. $0,25 \mathrm{ccm}$ ) das Gebärmutterhorn unterbunden, so dass die injicirte Flüssigkeit innerbalb eines kleinen Gebietes des Hornes eingeschlossen wurde. Diese Einrichtung wurde getroffen, um den Einfluss der Streptokokken während kurzer Zeit auf einem beschränkten Gebiet des Gebärmutterhornes zu beobachten und um womöglich die Wege zu ermitteln, auf welchen die Streptokokken aus dem Lumen des Gebärmutterhorns in das Gebärmutterhorn hineindringen. Die Thiere wurden kurze Zeit nach Anstellung des Versuches getödtet.

Versuch 17. 11.5 Okt. Vorm. $1 / 211$ Uhr. Kaninchen, welches geboren hat. $1 / 4 \mathrm{ccm}$ Streptokokkenbouillon wurde in das linke Horn eingespritzt. Unterbindung oberhalb und unterhalb der Stelle der Injection. Temp. den 12. Okt. Morgens $40^{\circ}$, Abends 6 Uhr 37,2. Das Thier wurde den 12. Okt. Nachm. 1/27 Uhr getödtet (Chloroforminhalation). Section unmittelbar daranf. Die Därme stark aufgetrieben, die Gefässe injicirt, der Inhalt dünnflüssig. Coecum mit fest adhärirenden grauweissen Belägen. Hier und da subseröse Ecchymosen. Keine 
eigentliche Ansammlung von Exsudat, aber bedeutende Vermehrung der Bauchfeuchtigkeit. Das rechte Gebärmutterhorn adhärent an der Bauchwand und Blase. Jedes der Hörner stark aufgetrieben mit lebhafter Gefässinjection, gegenseitig adhärent. Im rechten Horn dicker eiteriger Inhalt. Das linke Horn gleichförmig verdickt, sowohl innerhalb als ausserhalb der Unterbindung; oberhalb der oberen Ligatur dickflüssiger Inhalt, ähnlich dem im rechten Horne befindlichen. In der Scheide eiteriger Inhalt. Die Milz etwas geschwollen.

Bakteriologische Untersuchung. Von den Membranen und der Flüssigkeit in der Bauchhöhle zeigen Deckglaspräparate reichlich abgestossenes Endothel, theilweise zerfallene mono- und polyuucleäre Leukocyten, reichlich Streptokokken, meistens in kurzen Ketten. Der dicke zähe Eiter aus dem rechten (nicht injicirten) Horn zeigt polynucleäre Leukocyten, aber nicht Streptokokken. In Kultur von einer grossen Oese waren 2 Kolonien Streptokokken. Vom linken Gebärmutterhorn in Kultur ziemlich reichlich Streptokokken (etwa 100 Kolonien von einer Oese). Vom Peritoneam in der Gegend von Bauchwunde und Gebärmutter massenweise Streptokokken in Reinkultur. Vom Herzblut 4 Oesen: steril. Von der Leber 2 Oesen: steril.

Mikroskopische Untersuchung. Das nicbt injicirte Horn: Der untere Theil stark erweitert. Im Lumen eine compacte Masse, bestehend theils central aus einer amorphen Masse, theils (peripherisch) aus Leukocyten. Die Schleimhaut schmal, aber doch mit beibehaltenen Falten, mit spärlichen, kurzen Drüsen and ziemlich reichlich Gefässen. Jedes der Muskellager schmal; die Gefässe zwischen denselben dilatirt.

Die Leukocyten im Lumen sind meistens polynucleär. In der amorphen, nicht gefärbten Masse sind zerstreute Leukocyten zu sehen, deren Kerne zerfallen sind; mehrere kleine Köruchen, die nicht so distinkt gefärbt sind wie die Kerne in den in der Peripherie befindlichen Leukocyten. In dem höher hinauf gelegenen Theile des Hornes findet sich im Lumen eine kleinere Menge Eiter, hier sind die Leukocyten begsser gefärbt und mit feinen Granula völlig besetzt. Keine Streptokokken sind zu sehen. Die Schleimhaut ist mit Leukocyten stark infiltrirt; auch die ovalen Zellen sind stark an Zahl vermehrt. Oberflächliches und Drüsenepithel überall gat beibehalten. Die Leukocyten in der Schleimhaut sind meistens mononucleär. Selbst im Lumen der näher der Oberfläche gelegenen, quer durchschnittenen oder in das Lumen mündenden Drüsen sind auch Leukocyten zu finden. Längs dem äusseren Rande des Hornes Eiter mit spärlich Streptokokken, theils aJs Diplokokken, theils in kurzen Ketten, bis zu 5 Individuen. Die äusserst gelegene Bindegewebsschicht reichlich kleinzellig infiltrirt: mono- und polynucleäre Lenkocyten. $\operatorname{lm}$ oberfächlichen Theil des Bindegewebes sind Streptokokken zu sehen.

Das injicirte linke Horn. Im Lumen einige kleinere und grössere Anhäufungen von Leukocyten, theils mono- theils polynucleär, theils mit in mehrere Körnchen zerfallenden Kernen, theils mit Granula im Protoplasma, sowie von grossen amorphen Klumpen und von spärlich vorkommenden, einzelnen Streptokokken als Mono- und Diplokokken, sowie in kurzen Ketten.

Die Schleimhaut lappig, die Drüsen spärlich, im oberflächlichen Theile kleinzellige Infiltration, das oberfächliche und das Drüsenepithel beibehalten. Jede der Muskelschichten normal. Streptokokken sind nicht zu sehen. Längs dem äusseren Rande des Hornes hier und da 
Eiterhaufen mit einigen einzelnen Streptokokken, als Mono- und Diplokokken. Der äussere Theil des oberflächlichen Bindegewebes stellenweise kleinzellig infiltrirt, an anderen Stellen in normalem Zustande.

Cervix. In der Wand der Cervix in seinen Geweben und in seinen Blutgefässen, sowie gleichfalls im Lumen sind Leukocyten, welche alle scharf gefärbt Granula enthalten, $z u$ sehen. Einige von diesen sind gleichsam im Zerfall, der Kern oder die Kerne sind wohl noch rorhanden, aber die Granula rings um dieselben zerstreut. Am äusseren Rande haftet spärlich Eiter mit schwach gefärbten Streptokokken. Sonst sind nirgends derartige Bacterien zu sehen.

Scheide. Im Lumen hier und da Leukocytenhaufen, meist mono-, aber auch polynucläre, sowie eine feinkörnige Masse, aber keine Streptokokken. Die Schleimhaut beibehalten, die Muscularis unverändert. Am äusseren Theile der Scheide Eiterhaufen mit spärlichen Streptokokken, als einzelne Individuen, Diplokokken oder in Ketten.

Versuch 18. 15. Octbr. Vormittags $1 / 210$ Uhr. Grosses Kaninchen. $0,10 \mathrm{ccm}$ Streptokokkenbouillon wurde in das linke Gebärmutterborn eingespritzt; Unterbindung oberhalb und unterhalb der Stelle der Injection. Temp. 15. 10. Abends 40,0 $0^{\circ}$ Das Thier wurde den 16. 10. Vorm. getödtet. Section unmittelbar darauf. Stellenweise aufgetriebene Därme. Etwas Gefässinjection. In der Nähe der Bauchwunde an den Darmschlingen feine kleine Flöckchen. Die Bauchflüssigkeit reichlicher als normal. Das Peritoneum im kleinen Becken stark injicirt. Jedes der Gebärmutterhörner aufgetrieben. Das rechte Horn adbärent mit linken Parametrium. Das linke Horn zwischen deu Ligaturen stark aufgetrieben.

Bakteriologische Untersuchung. Ziemlich reichlich monound einzelne polynucleäre Leukocyten, aber keine Streptokokken in der Peritonealflüssigkeit. Im Sekret aus jedem der Gebärmutterhörner Epithelzellen, einzelne polynucleäre Leukocyten, aber keine Streptokokken (Deckglaspräparate).

Mikroskopische Untersuchung. Scheide: Hier und dort im Lumen einige Leukocyten. Streptokokken sind weder im Lumen noch in der Wand zu sehen. Dicht unter dem oberflächlichen Epithel im. Bindegewebe der Schleimhaut spärlich Leukocyten; solche treten auch zwischen den Zellen des oberfächlichen Epithels heraus. Cervix normal. Lumen frei; keine Streptokokken. Das nicht injicirte Gebärmutterhorn: Leukocyten bier unıl dort in geringer Menge am oberflächlichen Epithel, welches beibehalten wird. Der oberflächliche Theil des Bindegewebes der Schleimhaut mit Leukocyten und Bindegewebszellen in reichlicher Nenge. Die übrigen Theile der Wand normal. Nirgends sind Streptokokken zu sehen. Das injicirte Gebärmutterhorn oberhalb der Ligatur: Normale Schleimhaut mit spärlichen Drüsen. Kein Eiter im Lumen. Keine Streptokokken. Das Horn zwischen den Ligaturen erweitert. Im Lumen eine grössere Ansammlung von Eiter: poly- und mononucleäre Leukocyten, ein Theil mit reichlichen Granula. Spärlich Streptokokken hier und dort im Eiter zerstreut, zumeist am Rande desselben. Die Schleimbaut hinsichtlich der Dicke zum Theil beibehalten, zum Theil schmaler als gewöhnlich. Die bistologische Beschaffenheit derselben ist unverändert, nur dass das Bindegewebe nach der Oberfläche zu kleinzellig infiltrirt ist und die Bindegewebszellen der Zahl nach vermehrt sind. An der 
äusseren Oberfläche des Hornes findet sich kein Eiter, auch keine Streptokokken.

Versuch 19. 15. Octbr. Vorm. 11 Uhr. Kaninchen, das nieht geboren hat. $0,10 \mathrm{ccm}$ Streptokokkenbouillon in das linke Gebärmutterhorn, Unterbindung oberhalb und unterhalb der Stelle der Injection. A.-T. 38,5. Das Thier wurde den 15. 10. 9 Uhr Nachm. getödtet. Section unmittelbar darauf. Die Därme zum Theil leicht aufgetrieben und injicirt. Ziemlich reichlich seröse Flüssigkeit in der Bauchhöhle. Am linken Gebärmutterhorn leichte Verwachsungen; etwas Gefässinjection und subseröse Ecchymosen. Von den inneren Organen nichts Bemerkenswerthes.

Bakteriologische Untersuchung. Peritonealfiüssigkeit (Deckglaspräparate) zeigt ziemlich reichlich mononucleäre und einzelne poly. nucleäre Zellen, keine Streptokokken. Das Sekret aus jedem der Gebärmutterhörner: reichlich polynucleäre und weniger zablreich mononucleäre Leukocyten und Epithelzeilen. Keine Streptokokken. Culturen vom Gebärmuttersekret, von Peritonealfüssigkeit in der Nähe von und an Darmschlingen, und vom Blute aus Leber, Milz und Herz steril.

Mikroskopische Untersuchung. Scheide, Cervix und das nicht injicirte Gebärmutterborn normal. Keine Streptokokken. Das injicirte Horn zwischen den Fäden stark erweitert; die Schleimhaut beibehalten, stellenweise abgeplattet, die Drüsen spärlich, auf langen Strecken finden sich nur kryptenartige Drüsen. Im Lumen hier and dort kleine Leukocytenhaufen mit reichlichen Granula; Streptokokken sind nicht nachzuweisen. Das oberflächliche Epithel abgeplattet; zwischen die Zellen desselben treten Leukocyten mit reichlichen Granula heraus. Der obertlächliche Theil des Bindegewebes kleinzellig infiltrirt; die Leukocyten reichlich Granula enthaltend.

Das Thier No. 19 wurde 10 Stunden nach der Einspritzung getödtet. Die Därme zum Theil leicht aufgetrieben und injicjrt; ziemlich reichlich seröse Flüssigkeit. in. der Bauchhöhle. Das injicirte Horn leicht adhärent zu sich selbst; die Gefässe etwas injicirt, subseröse Ecchymosen. Peritonealflüssigkeit und Gebärmuttersekret enthalten reichlich Leukocyten, aber keine Streptokokken; solche auch nicht im Blute. Scheide, Cervix und das nicht injicirte Gebärmutterhorn normal. Das injicirte Horn zwischen den Ligaturen stark erweitert, die Schleimbaut stellenweise abgeplattet, das oberflächliche Epithel abgeplattet, der oberfächliche Theil der Schleimbaut kleinzellig infiltrirt. Im Lumen kleine Anhäufungen von Leukocyten. Nirgends sind Streptokokken zu entdecken. In diesen Fällen scheinen die Streptokokken einen gelinden Reiz der Schleimhaut und des Peritoneum verursacht zu haben, sind aber bald verschwunden. Wahrscheinlich würde das Thier die Wirkung der Infection überwunden haben und am Leben geblieben sein.

In Versuch 18 wurde das Thier 18 Stunden nach der Einspritzung der Streptokokken getödtet. Die Därme stellenweise auf- 
getrieben, das Peritoneum besonders innerhalb des Beckens stark injicirt. Jedes der Gebärmutterhörner, speciell das linke zwischen den Ligaturen aufgetrieben. Das rechte Horn adhärent zum linken Mesometrium. In der Peritonealflüssigkeit und in dem Gebärmutterinhalt Leukocyten, aber keine Streptokokken. Nur in der Eiteransammlung, die sich im Gebärmutterhorn zwischen den Ligaturen befindet, werden spärliche Streptokokken nachgewiesen, das Endometrium oberflächlich kleinzellig infiltrirt, sonst unverändert.

In diesem Falle war auch ein Reiz des Peritoneums und des Endometriums an der Stelle der Einspritzung vorhanden. Die Bakterien selbst wurden nur im Lumen des Gebärmutterhorns nachgewiesen. Vermuthlich war eine allgemeine Infection noch nicht zur Ausbildung gelangt oder war der Infectionsstoff von schwacher Wirkung.

Das Thier No. 17 wurde 32 Stunden nach Einspritzung der Streptokokken getödtet. Hier war Peritonitis mit eitrigen Belägen und Verwachsungen zur Ausbildung gelangt. Jedes der Gebärmutterhörner stark aufgetrieben. In dem nicht injicirten Horn, im injicirten Horn oberhalb der oberen Ligatur und in der Scheide dickflüssiger eitriger Inhalt. Bei Culturversuch zeigte sich das Blut steril, im Inhalt aus dem injicirten Horn und der PeritonealIlüssigkeit reichlich Streptokokken. Im Eiter im Lumen des nicht injicirten Gebärmutterhornes sind keine Streptokokken zu sehen, auch nicht in anderen Theilen des Hornes, ausser in und an der Oberfläche der äusseren Bindegewebsschicht. Das Endometrium ist stark kleinzellig infiltrirt. Im Eiter in dem injicirten Horn dagegen sind Streptokokken zu sehen, nicht aber in den verschiedenen Theilen der Wand selbst, welche bis auf eine kleinzellige Infiltration im oberflächlichen Theil des Endometriums unverändert sind. Nur an der äusseren Bindegewebsschicht sind Streptokokken zu finden.

In diesem Falle fanden sich Streptokokken sowohl in der Gebärmuttereavität als auch in der Peritonealhöhle, aber auf welchem Wege sie in die letztere gelangt, war nicht zu ermitteln, möglicherweise durch die Uterinwand, in der Nähe der Ligaturen. Eine Peritonitis hatte sich ausgebildet, aber eine allgemeine Sepsis war noch nicht entstanden, denn das Thier wurde getödtet, bevor noch eine solche hatte eintreten können.

In diesen 3 vorstéhenden Fällen wurde das Gebärmutterhorn an zwei Stellen nahe aneinander unterbunden und die Strepto- 
kokkenbouillon zwischen den unterbundenen Stellen eingeschlossen. Die damit beabsichtigte und dadurch entstandene Störung in den normalen anatomischen Verhältnissen des Gebärmutterhornes ist wohl den rasch eingetroffenen positiven Resultaten zuzuschreiben; selbst wenn die Schleimhaut und die übrige Wand des Hornes auf einem hinreichend grossen Gebiet intact war, was auch durch die mikroskopische Untersuchung dargethan wurde, war ja ein Hemmniss für den Abfluss der Sekretionsproducte der Schleimhaut vorhanden, was sich auch durch die Erweiterung des Hornes und eine, wenn auch beschränkte, Mortification der Gewebe an den unterbundenen Stellen zeigte - alles Umstände, die die Fähigkeit der Schleimhaut, die Infection zu überwinden, verringern und die Ausbreitung derselben begünstigen.

Folgender Versuch wurde an einem Kaninchen, das 8 Tage vorher geboren hatte und demnach sich im puerperalen Zustande befand, ausgeführt:

Versuch 20. 23. Oct. Nachm. 6 Uhr. Kaninchen, welches den 22., Nachm. 2 Uhr, Junge geworfen hat. In das linke Horn, zwei Finger breit vom Cervix, wurden $3 \mathrm{ccm}$ Streptokokkenbouillon eingespritzt. Keine Unterbindungen. Temp. 23. Okt. Abends 38,6 ${ }^{\circ}, 24$. Okt. Morgens $39,8^{\circ}$, Abends $40^{\circ}$. Das Thier wurde den 24. Okt., Nachm. $1 / 29 \mathrm{Uhr}$, getödtet.

Section unmittelbar darauf. Etwas Injection der Banchserosa und Vermehrung der Peritonealfeuchtigkeit. Die Harnblase adhärent zur Bauchwunde. Starke Injection und stellenweise Ecchymosen, speciell am linken Gebärmutterhorn und Parametrium.

Bakteriologische Untersuchung: Im Sekret aus dem linken Gebärmutterhorn sind poly- und mononucleäre Leukocyten und Epithelzellen zu sehen. Im Sekret aus dem rechten Horn nur einige vereinzelte Epithelzellen. In keinem der Sekrete Streptokokken. In der Peritonealflüssigkeit abgestossene Endothelien, spärlich polynucleäre, reichlicher mononucleäre Zellen. Alle, gerade wie im vorhergehenden Versuch, entnommenen Culturen steril.

Mikroskopische Untersuchung. Scheide: Im Lumen sind spärliche Anhäufungen von Leukocyten zu sehen: poly-, mononucleäre, mit Granula und im Zerfall, aber keine Streptokokken. Das oberflächliche Epithel beibehalten. In einigen der grossen Lymphräume unter dem oberflächlichen Epithel sind kleinere und grössere Leukocytenhaufen zu sehen; mononucleäre, mit Granula und im Zerfall. Unter diesen sind Streptokokken in langen und kurzen Ketten zu sehen. In den übrigen Theilen der Vaginalwand sind diese Bakterien nicht zu sehen.

Das injicirte Gebärmutterhorn: Jede der Muskelschichten stark hypertrophisch. Die Schleimhaut wieder gebildet, lappig, mit stark dilatirten Blutgefässen, Drüsen und oberflächlichem Epithel. Stellenweise sind im Bindegewebe der Schleimliaut Blutgerinnsel zu finden. Im Lumen, nahe dem oberflächlichen Epithel, spärlich Leukocyten, aber 
keine Streptokokken. In den grossen Lymphräumen des Mesometriums sind zwischen stark gefärbten Leukocyten, welche zumeist polynucleär und auch im Zerfall begriffen sind, spärlich Streptokokken zu sehen. Auch in den Venen des Mesometriums, welche rotbe Blutkörperchen und reichlich Leukocyten enthalten, sind eimige Streptokokken zu sehen.

Das nicht injicirte Horn wie das injicirte. Streptokokken sind nicht in demselben zu sehen, wohl aber in reichlicher Menge in den Lymphräumen und in den Venen des Mesometriums.

In Versuch 20 wurden 3 ecm Streptokokkenbouillon in das linke Gebärmutternhorn (ohne Unterbindungen) eines Kaninchens, das 20 Stunden zuvor geboren hatte, demnach in eine puerperale Gebärmutter eingespritzt. Etwas über 24 Stunden darauf wurde das Thier getödtet. Keine deutliche Peritonitis. Starke Infection und stellenweise Ecchymosen besonders an dem linken Gebärmutterhorn und Parametrium. Aus dem Inhalt in der Bauchhöhle und im rechten Gebärmutterhorn sind bei Culturversuchen keine Streptokokken zu erhalten. In den Lymphgefässen der Vaginalschleimhaut, in Venen und den Lymphgefässen der Mesometrien finden sich Streptokokken. Die Uterinschleimhaut wiedergebildet mit oberflächlichem Epithel und Drüsen, aber ihre Gefässe stark dilatirt. Jede der Muskelschichten stark hypertrophisch.

Zu bemerken ist, dass die Schleimhaut sich bereits 20 Stunden nach der Geburt wiedergebildet hatte. Streptokokken fanden sich in Lymphgefässen und Venen der Schleimhaut der Scheide und im Mesometrium. Wahrscheinlich hatten die Contractionen der Gebärmutter die Streptokokkenbouillon in die Scheide getrieben; die Infection war wahrscheinlich davon ausgegangen.

Wie aus diesen Versuchen hervorgeht, ist die Wirkong der Streptokokken sehr verschieden gewesen. In einigen Fällen haben sich die Thiere gegen den Infectionsstoff entweder immun gezeigt oder sie haben denselben mit Leichtigkeit überwunden, in anderen Fällen ist eine langsam verlaufende Infection mit tödtlichem Ausgange vorhanden gewesen, wobei das Thier stark abgemagert ist und gewisse weniger wesentliche Veränderungen dargeboten hat. Diese können als durch schwache Infection verursacht aufgefasst werden, die sich in den meisten dieser Fälle als von anderer Art gezeigt hat und häufig genug nicht von den Geschlechtstheilen ausgegangen ist.

In einem Theil der Versuche ist bald nach der Infection der Tod der Thiere eingetreten. Der Befund bei der Section, die Resultate der bakteriologischen und mikroskopischen Untersuchung 
des Streptococcus pyogenes auf die Schleimhaut der Gebärmutter ete. 329

sind gleichwohl nicht in allen Fällen gleich gewesen. In einigen entstand eine allgemeine Sepsis, wo vor dem bald eintretenden Tode besondere mikroskopische Veränderungen in den Geschlechtstheilen oder in der Bauchhöhle noch nicht zur Ausbildung gelangt waren. In anderen waren eine deutliche Peritonitis sowie mehr oder weniger ausgeprägte Veränderungen im Endometrium zur Ausbildung gelangt.

Nach meinem Dafürhalten bestätigen diese Versuche in dieser Hinsicht den allgemein anerkannten Umstand, dass verschiedene Individuen in verschiedener Weise auf denselben Infectionsstoff reagiren, vorausgesetzt, dass dieser virulent ist.

In Bezug auf die hauptsächliche Aufgabe bei diesen Versuchen, nämlich die Erforschung des Einflusses, den der Streptococeus auf die Scheiden- und Gebärmutterschleimhaut ausübt, und die Wege, längs welcher derselbe von Scheide und Gebärmutter in die Bauchhöhle, bez. den Organismus eindringt, haben einjge derselben recht interessante Aufschlüsse ergeben.

Die Veränderungen, welche durch den Einfluss des Streptococcus pyogenes in der Schleimhaut der Scheide und der Gebärmutter entstehen, sind am besten aus den Versuchen 4 und 11, aber auch aus den Versuchen 2, 3, 13 und 15 ersichtlich.

Es geht aus diesen Versuchen mit völliger Evidenz hervor, welche grosse Rolle das oberflächliche Epithel und die Zellen des Drüsenepithels bei der Einführung dieser inficirenden Bakterien in die erwähnten Organe spielt. Wo das Epithel intact und gesund ist, die Zellen zusammenhängen und mit gefärbten Kernen versehen sind, können die Streptokokken in der Regel nicht durch oder zwischen die Zellen nach dem darunterliegenden Bindegewebe und dessen Lymphgefässen vordringen. In solchen Fällen sind die Streptokokken längs dem oberfächlichen Epithel und an der Mündung einer Drüse gelagert, ja selbst wenn sie als einzelne Ketten innerhalb der Drüse zu finden sind, schützt das Drüsenepithel, wo dasselbe gut beibehalten und gefärbt ist. Aber an solchen Stellen der Scheide oder der Gebärmutter, wo das oberflächliche bezw. Drüsenepithel vermuthlich unter dem Einfluss des Infectionsstoffes nicht hat bestehen können, sondern sich in verschiedener Weise so verändert hat, dass die Zellen Zeichen von Degeneration darbieten, im Absterben mit schwach gefärbten Kernen begriffen sind, sei es, dass sie noch an ihrem Platze geblieben oder losgelöst sind und in gebrochener Kette unter dem Eiter im Lumen liegen, wie dies bei Wiedergabe der Versucho 4, 11, 13 mit diesbezüglichen Figuren 
näher geschildert wird, wird der Weg frei für die Streptokokken, um in das Bindegewebe der Schleimhaut vorzudringen, die alsdann in ihrem oberflächlichen Theile mit Leukocyten, läufig mit Kernen im Pyknos, kleinzellig infiltrirt gefunden wird, während die Bindegewebszellen gut beihehalten sind. Die Blutgefässe in der Schleimhaut sind dann reichlicher und dilatirt, wodurch die Zufuhr der Leukocyten im Kampfe des Organismus gegen die Infection an der Eingangsstelle begünstigt wird. Die Leukocyten sammeln sich an der Oberfläche des Bindegewebes und dringen von hier aus zwischen das oberflächliche Epithel und die Zellen der Drüsen nach dem Jumen vor, wo sie grössere oder kleinere Haufen bilden.

Bisweilen, wie in Versuch 4, können die Drüsen sich mit Leukocyten füllen, während das Epithel zerstört wird. In mehreren Versuchen ist die Eiteransammiung im Lumen des Gebärmutterhornes so stark gewesen, dass das Horn in recht hohem Grade erweitert und die Wand im Verbältniss dazu dünner geworden war. In den Fällen, Versuch 2 und 3, wo die Infection sehr rasch zum Tode führte, blieb der Schleimbaut keine Zeit, derartige Veränderungen durchzumachen, wie in den Fällen von Sepsis, welche etwas langsamer verliefen. Aber auch aus diesen Fällen ist die Bedeutung, welche das Epithel besitzt, ersichtlich. Wo dasselbe losgelöst oder degenerirt ist, obgleich nicht in so hohem Grade oder an so vielen Stellen, wie in den anderen Versuchen, dringen die Streptokokken in das unterliegende Bindegewebe und in dessen Lymphgefässe ein. Man findet zuweilen Streptokokken im oberen Theil des Protoplasmas der Zellen des oberflächlichen Epithels; es geht hier wohl ein Kampf vor sich zwischen Bakterien und Zellen. Zwischen die degenerirten Zellen seheinen die Streptokokken auch einzudringen und ebenso, wo dem Aussehen nach unverletzte Zellen auseinandergerückt sind und einen Zwischenraum frei lassen. An einigen Stellen (verg]. Fig. 11 Taf. VIII in Versuch 3 und Fig. 28 Taf. IX in Versuch 13) sind auch unter anseheinend unbeschädigten Zellen Bakterien zu finden. Es ist doch anzunehmen, dass die Zellen nicht mehr ganz normal gewesen sind oder sind die Streptokokken durch in der Nähe befindliche zugängliche Stellen gedrungen.

Wenn die Streptokokken unter das oberfächliche oder das Drüsenepithel gelangen, überschwemmen sie nicht das ganze Bindegewebe der Schleimhant, sondern halten sich gewöhnlich gesammelt im oberflächlichen Theile derselben, dringen aber von hier aus in die nahebei gelegenen Lymphräume bezw. Lymphgefässe, um durch 
Vermittelung des Lymphgefässsystems "weiter in den Organismus hinein, in erster Linie in die Bauchhöhle geführt zu werden. In den Fällen von acuter Sepsis sind auch in der Regel die Lymphgefässe im Bindegewebe der Gebärmutter und des Mesometriums reichlich mit Streptokokken besetzt gewesen, die auch im oberflächlichen Theil der nach der Bauchhöhle zu liegenden äusseren Bindegewebsschicht und in an dieser haftenden Eiteransammlungen (wohl aus der Bauchhöhle dahin gelangt) sowie in den Venen des Mesometriums und längs der Oberfläche desselben zu finden waren.

Tch habe nicht direct nachweisen können, auf welchem Wege die Bakterien von der Schleimhaut der Gebärmutter bezw. der Scheide in die Peritonealhöhle gelangt waren, aber aller Wahrscheinlichkeit nach muss dies wohl durch die Lymphgefässe in der Wand des Organes vor sich gehen, da in der Regel diese mit Streptokokken gefüllt und die Blutgefässe in der Regel frei waren.

Im Allgemeinen halten sich die Streptokokken innerhalb der Grenzen des Lymphgefässes auf, aber nicht gar selten sind sie auch im Bindegewebe in ihrer nächsten Umgebung, speciell im Mesometrium zu finden, in dessen Lymphgefässen und Venen sie sich in grosser Menge aufhalten und dessen Bindegewebe bez. Fettgewebe auch in höherem Grade von ihnen durehsetzt ist.

In den Versuchen 13 und 15, wo eine Mischinfection von Streptokokken und einer stäbchenförmigen Bakterie vorlag, verhielten sich diese letzteren in der Regel in gleicher Weise wie der Streptococcus, obgleich dieser mehr activ schien. Auch in diesen Fällen scheint der Untergang des oberfächlichen und des Drüsenepithels die Invasion der Bakterien begünstigt zu haben.

Bei Infection der Gebärmutter mit Streptococcus pyogenes kann man im Allgemeinen den Hergang folgendermaasser charakterisiren: Die Streptokokken streben Oberflächen- und Drüsenepithel zu verändern, so dass dieses seine schützende Eigenschaft einbüsst; Leukocyten aus den dilatirten Gefässen sammeln sich im oberflächlichen Theil der Schleimhaut und im Lumen. Es entsteht ein Kampf zwischen den Streptokokken und den Zellen und den Leukocyten; siegen diese letzteren, so geht die Infection zurück, die Bakterien werden durch die Leukocyten zerstört. Siegen die Streptokokken, so dringen diese in das oberflächliche Bindegewebe der Hucosa in deren Lymphgefässe ein und werden von hier weiter nach dem Mesometrium, der Bauchhöhle und den übrigen Theilen des Organismus transportirt. 
Um zu ermitteln, ob die erzielte Wirkung der Streptokokkenbouillon von den Bakterien selbst herrührte, habe ich einige Versuche mit Filtraten von Bouillonculturen ron Streptokokken verschiedenen Alters ausgeführt. Die Experimente wurden so gemacht, dass nach der Laparotomie das eine Gebärmutterhorn vorgezogen und mit einer sterilisirten Injectionsspritze durch die Gebärmutterwand $0,50-1,00 \mathrm{ccm}$ Filtrat in die Höhle hineingespritzt wurde. Das Horn wurde theils unterhalb, theils ober- und unterhalb der Stelle, wo die Injection stattfand, unterbunden. Die Thiere wurden zu verschiedenen Zeiten nach dem Versuch getödtet; die bakteriologische und mikroskopische Untersuchung geschah in gleicher Weise wie in den vorhergehenden Versuchen. Die Experimente sind folgende:

Versuch 21. 25. 9. Nachm. ${ }^{1 / 2} 7$ Dhr. Kauinehen, das nicht geborea hat. $0.50 \mathrm{ccm}$ Filtrat von 15 tägiger Bouilloncultur. Das Horn wurde unterhalb der Stelle der Injection unterbunden. Verlauf: Temp. 26. 9. M.-T. 39,1 , A.-T. 37,$8 ; 27.9$. M.-T. 38, A.-T. 38,1 ; 28. 9. M.-T. 37,8, A.-T. 36,6; 29. 9. M.-T. 38,2, A.-T. 37,8. Das Thier wurde den 29. 9. Nachm. 7 Uhr getödtet. Section: Keine Peritonitis. Die Harnblase durch dünne Membranen zur Baucbwand adhärent. Die Gebärmutterhörner nicht dilatirt, makroskopisch unverändert.

Bakteriologische Úntersuchung. Für Aussaat auf Agar und hohem Agar wurde Inhalt aus dem linken Gebärmutterhorn entnommen. Die Cultur steril.

Mikroskopische Untersuchung. Die Geschlechtstheile normal, nirgends sind Bakterien zu sehen.

Versuch 22. 28. 11. Nachm. ${ }^{1 / 2} 8$ Uhr. Kaninchen, das nicht geboren hat. In das linke Horn wird in gleicher Weise wie im vorhergehenden Versuch $1 / 2 \mathrm{ccm}$ Filtrat von 45 tägiger Bouilloncultur eingespritzt. Das Horn wurde unterhalb der Stelle der Injection unterbunden. Verlauf: 29. 11. M.-T. 38, 1, A.-T. 38,3; 30. 11. M.-T. 36,6; A.-T. 37 ; 1. 12. M.-T. 36,4 , A.-T. 36,$6 ; 2$ 2. 12. Nachm. 2 Uhr 36,9. Das Thier wurde Nachm. 3 Uhr getödtet. Section: Keine Peritonits. Das linke Horn etwas angesehwollen.

Bakteriologische Untersuehung. Deckglaspräparat vom Inhalt desselben zeigt keine Bakterien, nur einige Zellen und Schleim. Aussaat aut Agar, negatives Resultat.

Mikroskopische Untersuchung. Das rechte Horn unverändert. Das linke Horn nahezu unverändert. Das Lumen etwas weit. An einigen Stellen ist das Oberflächenepithel der Schleimhaut in geringem Umfange abgelöst. Die Zellen nebst einigen Leukocyten sind im Lumen $\mathrm{zu}$ sehen. Kleinzellige Infiltration kommt in der Schleimhaut nicht vor. Nirgends sind Bakterien zu sehen.

Versuch 23. 28. Nov. Nachm. 8 Uhr. Kaninchen, das nicht geboren hat. Versuchsanordnung wie bei dem vorhergehenden Versuche. $1 \mathrm{ccm}$ Filtrat von 45 tägiger Bouillonkultur.

Verlauf. Das Thier starb kurz nach der Operation. 
Section unmittelbar darauf. Die Gebärmutterhörner stark injicirt, dunkelroth von Farbe, das linke zur Stärke einer dünneren Bleifeder erweitert.

Mikroskopische Untersuchung. Das rechte Horn normal. Das linke etwas dilatirt. Jede der Muskelschichten schmal. Die Schleimbaut schmal. Die Drüsen kurz, ihre Zellen gleichsam gedrückt in der Richtung von innen nach aussen. Die Zellen des Oberflächenepithels niedrig. Keine kleinzellige Infiltration. Keine Leukocyten im Lumen.

Versuch 24., 28. Nov. Nachm. 81/2 Uhr. Kaninchen, welches vermuthlich zuvor geboren hat. Versuchsanordnung wie bei den vorhergehenden Versuchen, nur dass eine doppelte Unterbindung des Hornes vorgenommen wurde, nachdem $0,6 \mathrm{ccm}$ injicirt worden war.

Vorlauf. Temp. zwischen dem 29. Nov. und dem 12. Dez. zwischen 38 und $39^{\circ}$. Das Thier gesund. lebte noch am 26. Jan.

Versuch 25. 12. Dec. Grosses Kaninchen, welches nicht geboren hat. In das linke Horn wurde $1 \mathrm{ccm}$ Filtrat von 38 tägiger Bouillonkultur eingespritzt, nachdem das Horn zuvor aufwärts und unmittelbar nach der Injection unterhalb der Injectionsstelle unterbunden war.

Verlauf. 13. Dec. M. T. 38,4 , A. T. 38,8 . 14. Dec. M. F. 39,3 . Das Thier wurde um 12 Uhr Mittags getödtet.

Section. Keine Peritonitis. Die Bauchwunde leicht adhärent zum Fettgewebe des Mesenteriums. Das linke Horn zwischen den Ligaturen zur Stärke einer dickeren Bleifeder erweitert. Das rechte Horn normal.

Bakteriologische Untersuchung des Inhaltes aus dem Jinken Horn zeigt keine Bakterien.

Mikroskopische Untersuchung. Das rechte Horn normal. Das linke Horn ist zwischen den Fäden stark erweitert, selbst bis 6 bezw. $12 \mathrm{~mm}$ (am Schnitt gemessen). (Vergl. Taf. VIl, Fig. 12).

Jede der Muskelschichten sehr schmal. Die Schleimhant gleichfalls, bestehend aus einer dünnen Zone von Bindegewebe mit Blutgefässen, Oberflächenepithel, dessen Zellen niedrig sind, an mehreren Stellen mit dem längeren Diameter des länglichen Kernes in der Längsrichtung, und spärlichen, kurze Grübchen bildenden Drüsen. (Vergl. Taf. VII, Fig. 13). Kleinzellige Infiltration kommt nicht vor. Alle Epithelzellen Linsicbtich der Structur gut beibehalten, nicht in Degeneration. Hier und da längs der Oberfläche der Schleimhaut sind im Lumen Gruppen von spärlichen Leukocyten zumeist mononucleäre und solche mit zahlreicben Granula zu sehen.

Die übrigen Theile des linken Hornes sind in bedeutend geringerem Grade erweitert, die Schleimhaut ist dicker, mit zahlreicheren Drüsen.

Nirgends in oder neben den Hörnern sind Bacterien $\mathrm{zu}$ sehen.

Versuch 26. 12. Dec. Kaninchen, das nicht geboren bat. Versuchsanordnung wie bei Versuch 25 . $0,50 \mathrm{ccm}$ Filtrat von 38 tägjger Bonillonkultur.

Verlauf. 13. Dec. M. T. 37,6; A. T. 37,3. Das Thier starb in der Nacht auf den 14. Dec.

Section.15. Dec. vorm. 10 Uhr. Die Därme etwas aufgetrieben, leicht injicirt. Kein Exsudat; keine Adhärenzen. Das linke Horn zwischen den Fäden zur Stärke einer dickeren Bleifeder dilatirt. Das rechte Horn von normaler Grösse. 
Bakteriologische Untersuchung. Deckglaspräparat von der Peritonealflüssigkeit zeigt nur Epithelzellen, aber keine Bakterien. In der anaëroben Kultur von der Bauchflüssigkeit und dem Sekret aus dem linken Gebärmutterhorn ein Bacillus, aber in der anaëroben Kultur von der Bauchfeuchtigkeit und demselben Secret gehen keine Bakterien auf.

Mikroskopische Untersuhung. Das rechte Horn hat eine verhältnissmässig dünne Schleimhaut mit spärlichen Drüsen. Das linke Horn ist zwischen den Fäden stark erweitert. Die Schleimhaut in gleicher Weise wie in Versuch 25; das interstitielle Gewebe derselben ist reichlich mit länglichen Bindegewebezellen versehen. Hier und da im Lumen neben der Schleimhaut spärliche Leukocyten. Nirgends sind Bakterien zu sehen.

Aus diesen Versuchen scheint hervorzugehen, dass das Filtrat der Streptokokkenbouillon keine inficirende Wirkung gehabt hat. Es war keine andere makroskopische Veränderung des Gebärmutterhornes vorhanden, als eine starke Erweiterung der stelle, die sich zwischen zwei Ligaturen befand. Die von der Gébärmutterschleimhaut secernirte Flüssigkeit bäufte sich im Lumen und war im Stande, schon binnen kurzer Zeit den Gebärmuttercanal in hohem Grade zu erweitern. Es entstand eine Hydrometra. Wie die Gebärmutterwand unter derartigen Umständen verändert wird, wie die Musculatur ausgedehnt und diê Schleimhaut dünner wird, ist aus den Figuren 12 und 13 Taf. VII ersichtlich, die Veränderung ist augenfälliig beim Vergleich mit der Fig. 3, Taf. IV, die ein Bild von einem normalen Gebärmutterhorn giebt.

Weder im Sekret noch in der Gebärmutterwand kommen Bakterien vor; die Schleimhaut war nicht kleinzellig infiltrirt.

Nur das Thier No. 26 starb 2 Tage nach dem Versuch. In der anaëroben Cultur der Bauchfeuchtigkeit, des Sekrets aus dem linken Gebärmutterhorn ging ein Bacillus auf, aber es entwickelten sich keine Bakterien in der aëroben Cultur mit demselben Sekret.

Um die Wirkung sterilisirter Bouillon im Gebärmutterhorn za erproben, habe jeh in $z$ wei Versuchen direct in das Horn nach Unterbindung abwärts $0,50 \mathrm{bez}, 1,00 \mathrm{ccm}$ Bouillon injicirt. Die Thiere wurden nach 3 bezw. 6 Tagen getödtet. Das Horn war etwas dilatirt. Das Bindegewebe der Schleimhaut reich an länglichen Zellen, gleichsam in beginnender fibrillärer Anordnung. Einige Leukocyten im Lumen,

Um zu ermitteln, ob die Streptokokken aus der Banchböhle in der Nähe der abdominalen Mündung der Tube in das Lumen der Tube eindringen oder die Wand derselben von aussen nach innen durchdringen, habe ich folgenden Versuch ausgeführt. Ich 
führe den Versuch hier an, obgleich er nicht denselben Zweck wie die anderen gehabt hat.

Versuch 27. 23. Okt., Nachm. 1/28 Uhr. Kaninchen, das nicht geboren. Laparotomie. Ein kleines Stückchen Watte wird oberhalb des abdominalen Theiles der rechten Tube fixirt und mit 2 Tropfen Streptokokkenbouillon befeuchtet. Die Banchwunde wird geschlossen.

Verlauf: 24. Okt, Temp. 35,7. 25. Okt. Das Thier schwach, collabirt. 25. Okt. Vorm. todt.

Section. Ein Theil des Coecum verklebt mit Watte, die mit der Bauchwand vereinigt ist. Rings um das Coecum eine graugelbe Membran. Kein freies Exsudat, Die Gebärmutterhörner geröthet, leicht angeschwellt.

Bakteriologische Untersuchung: Deckglaspräparate von der Bauchféuchtigkeit zunächst der Watte und vom Herzblut zeigen Streptokokken.

Hakroskopische Untersuchung der Tube und des Gebärmutterhornes zunächst der Watte: Das Gebärmutterhorn unverändert, doch ist die Schleimhaut etwas gefässreicher als gewöhnlich. Im Lumen derselben sind keine Streptokokken zu sehen, wohl aber sitzen spärliche solche an der äusseren Oberfiäche derselben fest. An einigen Stellen sind in den Lymphgefässen und Venen des Mesenteriums Streptokokken 'zu sehen, die sich auch im Gervebe zunächst um die Lymphgefässe herum in den Adhärenzen, welche von der Oberfläche des Mesenteriums ausgehen, finden und an diesen anhaften. In den dünneren und dickeren, aus amorpher Masse und spärlichen Leukocyten bestehenden Adhärenzen, welche an der Mesosalpinx und ringsum die Fimbrien befestigt sind, sind zahlreiche Streptokoklen zu sehen.

Solche finden sich auch, wenngleich spärlich. längs dem Oberflächenepithel der Fimbrien, und, wo dieses sich auf einer langen Strecke gelöst hat, unter demselben, längs dem, wie auch oberflächlich innerhalb des entblössten Bindegewebes. In der Mesosalpinx des schmäleren Theiles der Tube (weiter weg vom Gebärmutterhorn) finden sich zahlreiche Streptokokken in an der Oberfläche haftender amorpher Masse und Lenkocyten. Aber im Fettgewebe der Mesosalpinx ebenso wenig wie in den Lymphgefässen oder Venen derselben sind Streptokokken zu sehen. Nach der Schicht von Zellen zu, welche sich an der Oberfläche der Mesosalpinx befinden, sind die Streptokokken in grosser Menge gelagert, dringen aber in der Regel nicht in das Gewebe selbst hinein, wenn diese Zellschicht unverletzt ist; wo diese Zellen fehlen, sind Streptokokken im oberfiächlichen Theil der Fettschicht der Mesosalpinx zu finden. An der äusseren Oberfläche der Tube haften spärlich Streptokokken. Innerhalb der Tube sind keine Bakterien zu sehen.

Aus diesem Versuch, der als der einzige für den damit beab-

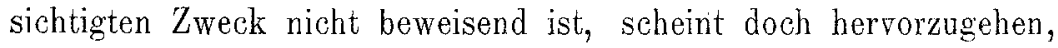
dass die Strektokokken aus der Bauchböhle in der Nähe der Mündung der Tube nicht in die Tube hineinwandern, sondern sich auswendig auf derselben und längs der Oberfläche der Fimbrien und der Mesosalpinx befinden und sich verhalten, wie aus der 
Beschreibung erhellt. Sie bewirken anch hier eine Ablösung der Epithelzellen.

Es lag nahe vorauszusetzen, dass die Forscher schon mit der Zeit, da man die Mikroorganismen als die Ursache der verschiedenen Aeusserungen der puerperalen Infection beim Menschen betrachtet hat, versuchen würden, durch Infection der Geschlechtstheile won Thieren im nicht puerperalen oder im puerperalen Zustande ähnliche pathologische Veränderungen hervorzurufen. Seit dem Ende der 1880 er Jahre hat man durch Einführung von Eiter oder von virulenten Culturen pathogener Bakterien verschiedener Art in die Gebärmutter und in die Scheide verschiedener Thiere, gewöhnlich Kaninchen, aber auch Meerschweinchen oder Hunde, versucht, eine Infection der Thiere zu Wege zu bringen. Gewöhnlich hat man die Versuche an Thieren ausgeführt, welche kürzlich geboren hatten, um auf solche Art eine puerperale Infection hervorzurufen, zu den Versuchen aber auch Thiere in Schwangerschalt oder solche mit normaler Gebärmutter- oder Scheidenschleimbaut oder mit einer solchen in verschiedener Weise verletzten benutzt.

Da diese Versuche in gewissem Grade die von mir ausgeführten berühren, werde ich zunächst eine kleine Beschreibung derselben geben.

Straus und Sanchez-Toledol) injicirten in den frischen puerperalen Uterus des Meerschweinchens und Kaninchens Reinculturen von Milzbrandbacillus, Vibrio septica, Staphylococcus pyogenes aureus und Bakterien der Hühnercholera. Die von Zeit zu Zeit mit der Platinnadel entnommenen Proben aus dem Innern des Uterus ergaben in Culturen ein negatives Resultat, die Bakterien werden darin schnell zerstört, mit Ausnahme der Hühnercholera-Bacillen. Die hiermit inficirten 2 Kaninchen starben, alle anderen erkrankten nicht.

Peraire ${ }^{2}$ ) hat aus dem Gebärmuttersekret bei septischer Endometritis Bacillen und Kokken rein gezüchtet und aus einer Bouilloncultur von diesen in die Scheide von Kaninchen und Hunden kleine Mengen einoculirt. Die Thiere bekamen Fieber, Vulvitis und Vaginitis, wobei im Sekret aus Vulva und Scheide dieselben Bakterien nachgewiesen werden konnten, aber nach einigen Tagen hörten die Symptome auf. Zweimal wurde Skarifikation der Scbleimhaut der Gebärmutter ausgeführt, worauf 2 Tage bindurch ein sero-sanguinöser Ausfluss und Congestion des Organes vorhanden waren, aber keine Ulcerationen, auch keine persistirende Endometritis.

1) Recherches microbiologiques sur l'uterus après la parturition physiologique. Annales de l'institut Pasteur. II. Année. 1888. p. 426.

2) Endométrites infectieuses etc. Thèse de Paris. 1889. p. 21, 22. 
Widall) hat fünfmal in die Gebärmutter eines Kaninchens, das kurz zuvor geboren hatte, Streptococcus pyogenes injicirt, aber ohne Resultat, ausser in einem Falle, wo in der Scheidenwandung ein localer Abscess entstand.

Nach Woskressensky ${ }^{2}$ ) riefen die Injectioneu von Staphylococcus citreus in die Gebärmutterhörner des Kaninchen eine locale Exsudation ohne Uebergang auf das Peritoneum und ohne weitere Störung des Gesammtorganismus hervor.

Um die Entwicklung der Infection in den weiblichen Geschlechtstheilen zu studiren, führte Giglio ${ }^{3}$ ) Versuche an Hunden, Meerschweinchen und Kaninchen aus. Das septische Material bestand aus Fiter von Abscessen, blennorrhagischem Eiter und Reinculturen von Streptococcus pyogenes aureus, albus, citreus, Bacillus pyocyaneus. Die Infectionsstoffe wurden in die Scheide mit gesunder und verletzter Wand, in das Corpus uteri, in die Gebärmutterbörner, in die Tuben, in die Ovarien; in die Lig. lata, in das Bindégewebe des Beckens, in die Fossa Douglasii and in die Fossa vesico-uterina eingefübrt. Er fülurte Versuche an etwa 40 Thieren aus und erbielt in 13 Fällen deutliche pathologische Folgen. Bei der Infection der eigentlichen Geschlechtsorgane waren die Resultate- kurzweg folgende:

Injectionen von Eiter aus Abscessen, von gonorrhoischem Eiter und von Reinculturen in die Scheide mit unverletzter Wandung machen keine sonderliche Wirkung. Injectionen in die Scheidewand und in die Scheide nach Läsion der Schleimhaut bewirken mehr oder weniger heftige Entzündungen in und in der Nähe der Läsionen. Die Entzündung in diesen Fällen erstreckt sich nicht über die Scheide und das Collum uteri; die Congestion in den Gefässen ist zumeist deutlich an den Seiten der Scheide, in den Geweben um dieselben und um die Blase. Ein einziges Mal umfasste bei einem Kaninchen die Entzündung alle inneren und äusseren Geschlechtsorgane. Die Gefässe in den Beckenorganen waren congestionirt und boten die Erscheinungen von Diapedese mit perivasculären Blutungen dar. Bei Hunden wurde ein Katarrh in der Schleim haut der Scheide und am Collum uteri vorgefunden; das Bindegewebe war in einem Zustande von Proliferation mit kleinzelliger Infiltration; die Muskelschichten und die Gefässe waren in gleicher Weise verändert. Die Tuben, die Ovarien, die Gebärmutterhörner und das Corpus uteri waren gleichfalls congestionirt.

Injection in das Scheidengewölbe und iu die Portio vaginalis des Collum uteri verursachte schwere Läsionen. In einem Falle ging die Entzündung nicht auf das Corpus uteri, soudern auf die grossen uterovaginalen Gefässe über, indem sie die Gewebe im Becken und in den Lig. lata umfasste. Sodann ging die Entzündung auf die Tuben, die Gebärmutterhörner und die Gebärmutter über, in welchem Organe die Läsionen wenig bedeutend waren. In diesem Falle war eine Phlegmone

1) Bitude sur l'infection puerperale, la phlegmasie alba dolens et l'erysipele. Tèhse de Paris. 1889. p. 20.

2) Exp. Untersuchungen über die Pyo- und Hydrosalpinxbildung bei den Thieren. Centralbl. f. Gynäk. 1891. No, 42.

3) Osservazioni anatomo-cliniche-sperimentali sopra i flemmoni pelvici e le ovaro-salpingiti e sulle loro cura. Annali di ostetricja e ginecologia. 1893. No. 5. S. 416 . No. 6 . S. $491,518$. 
im Lig. Latum vorhanden. Die histologischen Läsionen waren bedeutend an den Injectionsstellen, in den Lig. lata und am äusseren Theil der Gebärmutterhörner, wo Ulcerationen und Zerstörung des Epithels vorhanden waren. In den Tuben kdmen Zerstörung des Epithels und Zellinfiltration im submucösen Bindegewebe vor. In den Lig. lata und in den Ovarien waren die Läsionen insbesondere perivasculäre.

Die Injectionen in das Corpus uteri bewirkten wenig bedeatende oder keine Läsionen.

Die Injectionen in die utero-ovarialen Gefässe verursachten häufig eine allgemeine oder acute Infection.

Die Injectionen in die Gebärmutterhörner verursachten schwere locale Läsionen, besonders um die Blutgetässe herum; Blutungen in der Wand, endarteritische Veränderungen und Stase in den perivasculären Lymphräumen; in der Schleimhaut kamen Veränderungen in den Zellen vor.

Caselli1) publicirte 1899 seine Versuche über die Einwirkung des Streptococcus erysipelätis. Die an Kaninchen angestellten Versuche zerfielen in vier Reihen: 1. Wirkung der Streptokokken bei Einführung in den leeren Uterus mit verletzten Wandungen, 2. Wirkung der Streptokokken bei Einführung in den graviden Uterus mit verletzten Wandungen, 3. Wirkung mit Streptokokken inficirter Tampons in der verletzten Scheide, 4. Wirkung infieirter Tampons in der gesunden Scheide trächtiger Kaninchen.

Die Ergebnisse der vier Versuchsreihen waren:

1. Reihe. Nach gründlicher Desinfection der Hände des Operateurs, auch der rasirten Bauchhalit des Kaninchens, wird mit sterilem Messer ein Längsschnitt von der Symphyse bis zum Nabel gemacht und die Bauchhöhle unter schichtweiser Durchtrennung der Banchwand eröffnet. Hierauf wird das rechte Uterushorn hervorgeholt, mit zwei Fingern festgehalten und nun mit einer sterilisirten Pravazspritze $2 \mathrm{ccm}$ einer Bouillonkultur des Erysipelcoccus durch die Uteruswand in die Gebärmutterhöhle eingespritzt. Nachdem die Nadel zurückgezogen, wird die Einstichstelle sofort mit dem Thermocauter behandelt, wodurch das Einfliessen der Kultur in die Bauchhöhle bis auf eine minimale Menge verhindert wird. Zuletzt werden die Bauchdecken schichtweise vernäht und die Nahtlinie mit Collodium bestrichen.

Die vier so behandelten Versuchsthiere starben in Zeitraum von 1-3 Tagen an Septikopyämie. Die Streptokokkeninfection wurde durch bakteriologische Untersuchung der bei der Section entnommenen Stücke bestätigt.

2. Reihe. Laparotomie. Das linke Uterushorn, welches zwei etwa 20 Tage alte Föten enthält, wird hervorgeholt und in dem Zwischenraume zwischen beiden Föten $2 \mathrm{ccm}$ derselben Bouillonkultur in die Uterushöhle eingespriizt.

Die beiden so behandelten Thiere abortirten nach 12 Stunden und gingen nach 26 bezw. 28 Stunden an Septikopyämie zu Grunde. Die Diagnose wurde durch das Milkroskop bestätigt. Bei zwei weiteren Thieren wurde nach Eröffnung der Bauchhöhle aus dem rechten Uterushorne ein 20 Tage alter Fötus durch Sectio caesarea entfernt und in die leere Höhle nach schichtweise angelegter Naht der Uteruswand

1) Experimentelle und bakterielle Untersuchungen über das Puerperalfieber. Centralbl. f. Bakteriologie etc. XXV. 1899. S. 5. 
2 ccm der Streptokokkenkuitur eingespritzt, worauf die Báuchwunde geschlossen wurde. Die beiden Thiere abortirten nach 36 bezw. 43 Stunden und die mikroskopische Untersuchung ergab dieselbe Todesursache wie bei dem vorhergehenden Thiere.

3. Reihe. Dem Kaninchen werden mittels einer Sonde zwei Wunden an der Vaginalschleimbaut beigebracht und darauf ein kleiner mit Streptokokkenkultur getränkter Wattetampon hoch in die Scheide hineingeschoben. Das Thier wird sich selbst überlassen, der Tampon jeden Tag erneuert. Vier so behandelte Thiere starben bezw. 3, 4, 7 und 8 Tage nach dem Eingriffe. Bei der Section fanden sich schwere Veränderungen in allen Organen in Folge Streptokokkeninfection.

4. Reihe. An drei Kaninchen wird mit einer Glassonde unter sorgfältiger Vermeidung jeder Schleimhautverletzung ein mit Streptokokkenkultur getränkter Tampon in die Scheide gebracht. Die Versuche bewiesen, dass der in die gesunde Vagina eingeführte Streptococcus lange Zeit virulent bleibt, sodass er noch bei einer 45 Tage später eintretenden Geburt eine lebensgefährliche Erkrankung des Thieres verursacht. Die Erkrankung trat unter verschiedenen Formen auf: bald kam es zur acuten Allgemeininfection, bald zu Abscessen im Becken. Perioophoritis, Salpingitis oder zu embolischen Eiterungen in entfernt liegenden Organen.

Die Resultate der Versuche von Morisani an Meerschweinchen ${ }^{1}$ ) sind folgende:

Eine intrauterine Injection von $1 / 2$ bis $1 \frac{1}{2} \mathrm{ccm}$ von einer Bouillonkultur (48 Stunden à $37^{\circ}$ ) von Bacterium coli verursachte weder locale noch allgemeine Störungen. Nach Läsion der Gebärmutterschleimhaut durch Abschabung oder Injection von heissem Wasser oder Behandlung mit einer 2 proc. Lapislösung (um ihre bactericide Eigenschaft aufzuheben und kleine nekrotische Herde und Wunden hervorzubringen) wurden 1 bis $2 \mathrm{ccm}$ von einer virulenten Kultur von Bact. coli injicirt. Alle Versuchsthiere (12 an der Zahl) starben binnen 14 bis 52 Stunden in Folge von Endometritis (Bact. coli) complicirt mit septischer Peritonitis. Varnier giebt die Beschreibung eines der Experimente: Injection in die Gebärmutter von heissem Wasser, sodann $1 \mathrm{ccm}$ Kultur von Bact. coli. Binnen 24 Stunden ist das Thier krank, die Temperatur erhöht, die äusseren Geschlechtstheile geröthet, fötide Sekretion, gelinde Auftreibung des Bauches, starke Diarrbne. Tod nach 32 Stunden. Bei der unmittelbar darauf vorgenommenen Section wird eine starke septische Peritonitis mit Belägen aıf und Hyperämie in den Organen gefunden. Bei Impfung mit Peritonealflüssigkeit wird eine Reinkultur von Bact. coli erzielt. Die Gebärmutter vergrössert, hyperämisch, die Schleimhaut mit einem reichlichen muco-purulenten Sekret bedeckt. Das Epithel und die obere Schicht der Schleimhaut sind an einigen Stellen völlig zerstört, bedeckt mit Eiter und Bacterien. Das Epithel der Drüsen ist an einigen Stelien in Proliferation, aber vollständig losgelöst, an anderen Stellen gänzlich verschwunden. Die Zellen haben ibre Cylinderform verloren, sind cubisch und trübe. Einige Drüsen sind cystös erweitert, mit Epithel bedeckt und mit Schleim gefüllt. In dem iuterglandulären

1) Dell azione del bacterium coli commune sull' endometrio. Archivio di Ost. e Gin. 1897. (Ref. nach Varnier, La pratique des accouchements Obstetrique journalière. Paris. 1900. p. 379. 
Bindegewebe finden sich zahlreiche Leukocyten. Die Gefässe sind mit weissen Blutkörperchen gefüllt und umgeben. Nichts Abnormes in der Muscularis. Die Lymphräume sind dilatirt und mit einer homogenen Substanz gefüllt, in der sich Bacterien zeigen. In Leber, Milz und Nieren sind zahlreiche metastatische Herde mit Bacterium coli zu finden.

Klitin') hat eine Reihe von Versuchen an Kaninchen, die unlängst geboren haben, ausgeführt, um die Veränderungen des Uterus bei acuter puerperaler Infection, je nachdem, ob. dieselbe mit Antistreptokokkenserum behandelt oder nicht bebandelt wurde, zu bestimmen. Die Kaninchen wurden mit lebenden Culturen der Streptokokken gleicher Giftigkeit von einer Angina phlegmonosa inficirt. K litin injicirte die Culturen in die Hörner und in die Höhle der Gebärmutter, in die Scheide direct durch Reibung der Wand; ausserdem machte er subcutane und intravenöse Injectionen. Parallel wurde auch der Uterus von nicht inficirten, im Puerperium sich befindenden Kaninchen untersucht.

Anf Grund seiner Untersuchungen zieht Klitin folgende Schlüsse: 1. Veränderungen im Uterus von Kaninchen, die uxlängst geboren haben, bei Einführung einer Cultur von giftigen Streptokokken in den Uterus selbst, sind denen bei Einfübrung der Cultnr in das Blutgefässsystem fast vollständig gleich. Anhäufung der Granulationselemente an der Oberfläche der Schleimhaut und in der Tiefe derselben. In der Schleimhant und in der Muscularis sind reichlich abgestorbene Theile vorhanden, die mit Streptokoklen gefüllt sind. Die Blatgefässe sind in Folge der Anwesenheit von körnigen Massen, die dieselben Mikroorganismen enthalten, erweitert und von einer kleinen Menge mononucleären Leukocyten umgeben. Das Gefässendothel ist geschwollen. Reactive Durchtränkung mit Granulationselementen und weissen Blutw körperchen ist gering ausgesprochen. Diese Veränderungen beobachtet man wie bei der Früh-, so auch bei der Spätinfection.

2. Bei der Infection durch die Vaginalschleimhaut, anch durch das Unterhautzellgewebe sind die Veränderungen im Uterus ihrer Art und Verbreitung nach von der Zeit der Infection abhängig. In Fällen früher Infection sind sie denen schon beschriebenen ähnlich mit dem Unterschied, dass sie nicht so stark ausgesprochen sind; das Gefässendothel bleibt unverändert. In Fällen später Infection ist das Muskelgewebe theilweise hyalin verändert, zellige Elemente sind in grosser Menge, Streptokokken in geringer Menge vorhanden. Erweiterte Blutgefässe enthalten in sich viele Blutelemente. In den Fällen, wo das Antistreptokokkenserum angewendet wurde, stellt das Serum die Zellenelemente in solche Bedingungen, bei denen die Wirkung der Streptokokken im Körper abgeschwächt wird.

Die ausführlichsten Untersuchungen über die Einwirkung der Bakterien auf die Gebärmutterschleimhaut sind von Roudino²) gemacht

1) Histologische Veränderungen des puerperalen Uterus in Fällen der acuten Streptokokkeninfection bei Anwendung des Antistreptokokkensernm und ohne derselben (russisch). Wratseh. 1901. No. 24 u. 25. Ref. La Gynécologie. 15. Aout. 1901. p. 357 und Centralbl. f.,Gyn. 1902. No. 8. S. 219.

2) Ricerche sperimentali sulla patogenesi e sull' istologia patologica dell' infezione endouterina post partum. Archivio di ostetricia e ginecol. VI. 1899. No. 1--2. 
worden und seine Resultate stimmen der Hauptsache nach mit den meinigen überein, obwohl jene an Hunden und unter anderen Umständen gemacht worden sind als meine Versuche. Um die progressive Entwicklung der Veränderungen in der Gebärmutter nach der Injection von Mikroorganismen in dieselbe studiren zu können, wartete er nicht den Tod der Thiere ab, sondern tödtete dieselben nach der bestimmten Zeit von 24 Stunden. Er verwendete als Versucbsthiere meistens Hunfe, aber auch Kaninchen (2 Versuche mit Streptokokken), welche 10-20 Stunden vor dem Versuch geboren hatten. Er injicirte mit einem elastischen Katheter per vaginam in die puerperale Gebärmutter virulente Culturen von Streptococcus, Staphylococcus, Bact. coli, Bacillus diphth., Bacillus anthracis, und Mischungen zweier Arten von Mikroorganismen.

Rondino fand, dass die Entwicklung der in Folge von Infectionen, welcher Art die Mikroorganismen auch gewesen sein mögen, entstandenen Veränderungen in der Gebärmutter im Allgemeinen auf zwei Arten vor sich gehen. In den meisten Fällen vermehren sich die Bakterien stark auf der Oberfläche der Schleimhaut und dringen alsdann in die Mündungen der Drüsen ein. An einigen Stellen gehen sie durch das Oberflächenepithel, dringen aber leichter in das interglanduläre Gewebe ein an den Stellen, wo das Oberflächenepithel fehlt. Das Epithel erleidet eine trübe Schwellung, Fettdegeneration, wozu sich später Plasmolyse und an einigen Stellen auch Nekrose gesellt. Das Lumen der Drüsen ist erweitert und enthält mehr oder weniger weichliches, oft mit Eiterkörperchen bemengtes Exsudat. Das Epithel ist an diesen Drüsen am meisten an der Mündung verändert, in gleicher Weise wie das Oberffächenepithel. Das Bindegewebe zwischen den Drüsen ist selten verändert. Nur auf dem Gebiet der Insertion der Placenta, wo die locale Infection am stärksten ausgeprägt ist, findet man das Bindegewebe in nekrotischem Zustande. In den übrigen Schichten der Gebärmutterwand sind die Veränderungen im Allgemeinen wenig ausgeprägt. Neben diesen "passiven "Veränderungen kommen "active" solche vor, bestehend in Erweiterung der Blutgefässe und einer kleinzelligen Infiltration im Bindegewebe und im Epithel, am ausgeprägtesten an den Stellen, wo die Bakterien am zahlreichsten sind. An mehreren Stellen sieht man Bakterien in Leukocyten eingeschlossen. In den Fällen, wo die Untersuchung mehrere Tage nach der Infection gemacht worden ist, werden Bakterien nur an ganz wenigen Stellen beobachtet und die kleinzellige Infiltration ist in bedeutendem Grade verringert oder hat aufgehört. Die vorstehend beschriebenen Verändernugen in der Schleimbaut kamen in den Fällen von Infection von Hunden mit Bakterien verschiedener Art vor. Der Organismus ging in diesen Fällen stets als Sieger hervor, konnte schliesslich die eindringenden Mikroorganismen zerstören und sich derselben entledigen. Die nelsrotischen Theile der Schleimhant wurden ausgestassen und die Gewebe ersetzten sich.

In anderen Fällen war der Hergang ein ganz anderer. Die Infection entwickelte sich rasch, progressiv; die Reaction des Organismus gegen Infection war von negativem Erfolg. Die Bakterien verbreiteten sich in allen Geweben, drangen in die Lymph- und Blutgefässe oder in die einen derselben ein; meistens wurde der Transport der Bakterien durch die Lymphgefässe vermittelt, weniger oft durch die Blutgefässe, was bei den durch Streptococcus inficirten Kaninchen der Fall war, wo 
die Bakterien in und durch die in Folge der Entbindung lädirten Venen drangen, sich rasch im Organismus vermehrten und eine allgemeine Sepsis zu Wege brachten. Die Reaction durch die Leukocyten war sehr verschieden in den verschiedenen Fällen und von der Beschaffenheit der Infections- und Intoxicationsproducte abhängig. Die Infection kann sich so rasch entwickeln, dass jeder Austritt von Leukocyten unmöglich wird, der Organismus hat nicht Zeit, auch keine Möglichkeit, seine eigenen Vertheidigungsmittel zu entwickeln, die im Kampf gegen die Infectionsstoffe unterliegen. In anderen Fällen sieht man die Leukocyten nicht mehr gut beibehalten, oder deutlich gefärbt, sondern sie haben in höherem oder geringerem Grade regressive Veränderungen durchgemacht und haben so ihre Functionsfähigkeit eingebüsst. In Folge der Zerstörung der Bakterien oder ihrer Producte erleiden die Leukocyten Veränderungen und gehen schliesslich zu Grande.

Im Allgemeinen ist die Entwicklung dieser intrauterinen Infection folgende: Die injicirten Bakterien halten sich zuerst in den Falten der Schleimhaut und in den oberflächlichen Drüsen auf, dann vermehren sich die Bakterien, mit Ausnahme der Staphylokokken, mehr oder weniger stark und dringen tiefer in das Gewebe ein. Sie durchdringen mit Schwierigkeit das Epithel, denn dieses bildet gewöhnlich eine kräftigen Schutz gegen das Eindringen von Mikroorganismen, obwohl man immerhin in mehreren Präparaten sehen kann, dass die Bakterien gerade durch das Epithel in das Gewebe hineingelangen. Dadurch, dass es die Bakterien nur mit grosser Schwierigkeit durchfiltrirt, ermöglicht es den Lenkocyten, eine Anzahl der Bakterien einzuschliessen, und so deren Wirkung aufzubeben. Man kann, obwohl sehr selten, an einigen Stellen einige Leukocyten, in die Epithelschicht eingekeilt, einige Bakterien einschliessen sehen, die sich bei der Passage durch das Epithel angehäuft haben. Muthmaasslich durch die Einwirkung der Mikroorganismen oder der Producte derselben wird das Epithel verletzt und zweifelsohne bildet diese fortschreitende Veränderung eine bedeutende Verringerung der Widerstandsfähigkeit desselben, sodass der Durehgang der Bakterien möglich wird.

An der Placentarstelle, die vom Epithel entblösst ist, können Bakterien leichter durchgehen und sich im Gewebe ausbreiten, zumal sie in der reichlichen Menge von todten Gewebesubstanzen leicht colonisirt werden können. In einem grossen Theil der Fälle sind die Mikroorganismen in den oberflächlichen Theilen der Gewebe verblieben, ohne weiter hinunter gegen die Tiefe derselben vorzudringen. Die verschiedenen Thiere verhalten sich verschieden. Beim Hunde ist die Schleimhaut ein Filtrum für sämmtliche verschiedene Arten von Bakterien und nur unter gewissen Umständen, wenn die organische Resistenz durch locale Läsionen oder durch allgemeine Schwäche verringert ist, gehen einige Mikroorganismen durch die Schleimhaut, Streptococcus nicht so häufig wie Bacterium coli. Die injicirten Mikroorganismen durchdringen die Gewebe und üben die zerstörende Wirkung verschieden schnell aus, der Staphylococcus am wenigsten schnell. Die Kaninchen ;reagiren gegen Streptococcus auf eine ganz andere Art; diese gehen durch die Placentarstelle vor, dringen in die Blutgefässe hinein und breiten sich im ganzen Organismus aus; die Invasion geschieht in den grossen venösen Lakunen. Bei Hunden hat Rondino in der Placentarstelle in deren nekrotischen Geweben unzählige Leukocyten mit eingesehlossenen Mikroorganismen angetroffen, während er bei Kaninchen 
dieselbe Beobachtung nicht gemacht und bei diesen die Leukocyten im Allgemeinen sehr spärlich gesehen hat. Die Kaninchen bieten demnach nicht denselben Widerstand gegen die Invasion der Bakterien; dieser Mangel an protectiver Fähigkeit beruht wohl auf einer functionellen Inactivität bei den Leukocyten, die Mikroorganismen einzuschliessen und zu zerstören, oder darauf, dass ihrer bactericiden Kraft beraubte Gewebe einen günstigen Boden für' Cultur der Mikroorganismen darbieten.

Wie aus den vorstehend beschriebenen Versuchen hervorgeht, ist in einigen derselben die Technik nicht näher beschrieben worden, der Eiter oder die Kulturen der Bakterien sind in die Gebärmutter "injicirt" worden, ohne Angabe in welcher Weise, oder die Injection ist auch durch die Scheide oder direct in das Horn durch die Wand desselben (nach Laparotomie) geschehen. Da man weiss, wie schwer es ist, ohne vorerst die Bauchhöhle geöffnet und das Gebärmutterhiorn bei den Versuchsthieren hervorgezogen zu haben, durch den Muttermund die Injection in das Gebärmutterhorn auszuführen, ist die Unzuverlässigkeit derartiger Versuche leicht einzusehen. Dadurch, dass man nach Oeffnung der Bauchhöhle mit einer feinen Spritze die Flüssigkeit durch die Wand des Gebärmutterhornes injicirt, kann man die Flüssigkeit wohl in die Gebärmuttercavität hineinbekommen, aber die Möglichkeit, dass kleine Mengen der injicirten Flüssigkeit dureh die Gebärmuttercontractionen durch die. Einstichöffnung nach der Bauchhöhle getrieben worden, ist gleichwohl vorhanden. Die Infectionsflüssigkeit direct in die Scheide injieiren ist selbstverständlich nicht schwer.

Die meisten, die die vorstehend beschriebenen Versuche ausgeführt haben, haben die Infectionsflüssigkeit an Thieren injicirt, welche kürzlich geboren hatten, in der Vermuthung, dass die Infection von der puerperalen Gebärmutter aus leichter entstehen würde. Die Erfahrung hat indessen gelehrt, dass auch unter solchen Umständen die Versuche gewöhnlich ein negatives Resultat ergeben haben, darauf beruheṇd, dass die Gebärmutterschleimhaut bei den Versuchsthieren sich so rasch wieder gebildet, ihren gegen die Infection schützenden Bau und Eigenschaft wieder erhalten hat und so dem Einfluss der Infection hat widerstehen können. Ebenso ist das Resultat bei Injection in die Gebärmutter oder in die Scheide mit normalem, beibehaltenem Epithel gewöhnlich ohne Erfolg gewesen. Dagegen ist eine Infection meistens, wie es voraus zusehen war, eingetroffen, wenn die Schleimhaut des erwähnten Organes auf éine oder die andere Art verletzt worden war. 
Infieirende Lösungen in den Gebärmutterhörnern von Kaninchen zu deponiren, ist nur mit der von mir in allen meinen Versuchen bis auf die drei ersten angewendeten Technik möglich. Es ist sehr schwer, ja nahezu unmöglich per vaginam, ohne durch Laparotomie die Gebärmutterhörner für das Auge und für das Erfassen mit den Fingèr freizulegen, Flüssigkeit in eines der Gebärmutterhörner oder in beide zu injiciren. Es wird auf den Zufall ankommen, $o b$ es einem gelingt, durch die lange Scheide auf einen der kleinen, nahe beisammen liegenden Muttermünder zu treffen.

Auch wenn man voraussetzt, dass die Scheide des Kaninchens pathogene Mikroorganismen enthielt, welches doch Niemand bewiesen hat, ist es unmöglich die lange, enge Scheide des Thieres vor dem Versuche steril zu machen.

Das Resultat derartiger Versuche an Thieren auf den Menschen anzuwenden, ist nach meiner Meinung im allgemeinen nicht rathsam. Der Mensch und verschiedene Thierarten verhalten sich doch auf verschiedene Art in Bezug anf die L̇mpfänglichkeit für die Infection durch verschiedene Bacterien. Die Geschlechtstheile des Menschen und der Thiere, sowohl der Raubthiere als auch der Nagethiere, sind in gröberer anatomischer und feinerer histologischer Beziehung recht verschieden. Die Wiederbildung nach Entbindungen geht bei diesen Thieren viel rascher vor sich als beim Menschen. Die Tragweite derartiger Versuche an Thieren in Bezug auf die Erklärung pathogener Zustände beim Menschen ist sehr gering.

Meine Versuche haben nicht die Infection einer puerperalen Gebärmutter bezweckt und können demnach in keiner Weise bei dem Vergleich mit der puerperalen Infection beim Menschen herangezogen werden, wenn überhaupt ein solcher Vergleich puerperaler Verhältnisse zwischen Mensch und Thier in Frage kommen kann. Dieselben haben den Zweck gehabt, den Einfluss der Streptokokken theils auf eine völlig intacte Gebärmutter-, bez. Scheidenschleimhaut in grösserem Umfange, theils auf die Gebärmutterschleimhaut an einer mehr beschränkten Stelle oberhalb von oder zwischen Ligaturen zu studiren.

Meiner Meinung nach bestätigt das Resultat meiner Untersuchungen gleichwohl experimentell das klinisch beobachtete Verhältniss, dass das Oberfächenepithel und das Drüsenepithel der Gebärmutterschleimhaut nebst den austretenden Leukocyten den besten Schutz des Organismus gegen die nach der Gebärmutterhöhle geführten Infectionsstoffe bezw. die Streptokokken bildet. 
Das Verhältniss der Streptokokken zum oberflächlichen und Drüsenepithel der Gebärmutter in meinen Versuchen ist ziemlich ähnlich dem von Reymond beschriebenen Verhältniss derselben Bacterien in dem menschlichen Eileiter.

Im dem Eiter in von Streptococcus pyogenes inficirten Tuben hat Reymond $d^{1}$ relativ wenige Leukocyten, aber eine grosse Anzahl losgelöster Epithelzellen gefunden, welche der Form nach verändert sind und das perinucleäre Protoplasma eingebüsst haben. Häufig sind die Epithelzellen in einer Strecke losgelöst. Selten finden sich Streptokokken in den Leukocyten, häufiger in den Epithelzellen, meistens frei zwischen den Zellen.

In Fällen von mehr vorgeschrittener Salpingitis, wo die Tube noch offen ist, sind Streptokokken und Leukocyten in den Lymphgefässen zu finden, in den Falten ist das Epithel stellenweise nahezu intact, aber gleichwohl ohne Cilien, an gewissen Stellen findet sich eine Proliferation von Epithelzellen, unter welchen Gruppen von Streptokokken zu sehen sind. Bisweilen hat sich diese Zellproliferation von der Wand losgelöst und ist das Gewebe darunter mehr uder weniger von Streptokokken infiltrirt.

Es scheint mir, dass meine Versuche auch das besonders von Widal') und $\mathrm{Bumm}^{3}$ ) bei Menschen beobachtete Verhältniss bestätigen, dass hauptsächlich die Lymphgefässe des Uterus und das Parametrium dic fortschreitende Infection vom Endometrium vermitteln.

Die Frage über die Art der Einwirkung des Streptococcus pyogenes bezw. anderer pathogenen Mikroorganismen auf die Gebärmutterschleimhaut fordert noch die Anstellung vieler auf verschiedene Weise angeordneter Versuche. Ich hoffe in der Zukunft meine bis jetzt gemachten Versuche durch weitere Versuche ergänzen und dadurch zur Klarstellung der Frage beitragen zu können.

Auch die Frage, auf welchem Wege aus der puerperalen Infection sich eine Peritonitis entwickele, bedarf genauerer Antwort als der des Sectionstisches. Nur durch das Experiment und durch

1) Contribution à l'étude de la bacteriologie et de l'anatomie pathologique des Salpingo-ovarites. Paris. 1895. S. 101-106, 200.

2) 1.0 .

3) Histologische Untersuchungen über die puerperale Endometritis. Dies. Archiv. Bd. 40. 1891. H. 3. S. 398 und Kellexsmann, Zur Aetiologie der puerperalen Peritonitis. Diss. Würzburg. 1890. S. 409, 410. 
das Mikroskop lässt sich die Verbreitung der pathogenen Mikroorganismen feststellen.

\section{Erklärung der Abbildungen auf Tafel IV_-IX.}

$$
\text { Tafel IV-VII. }
$$

Fig. 1. Normale Vagina. Vergr. $10: 1$.

Fig. 2. Normale Cervix. Vergr. $10: 1$.

Fig. 3. Normales Gebärmutterhorn. Verg. $10 ; 1$.

Fig. 4. Normale Tube. Verg. 22,5:1.

Fig. 5. Inficirte Gebärmutter. Rechts inficirtes Horn, links normales Horn. Versuch 4. Vergr. $13: 1$.

Fig. 6. Inficirtes Gebärmutterhorn höher hinauf. Versuch 4. Vergr. 10:1.

Fig. 7. Nicht inficirtes Gebärmutterhorn, höber hinauf. Versuch 9. Vergrösserung $10: 1$.

Fig. 8. Inficirte Vagina. Versuch 4. Vergr. $10: 1$.

Fig. 9. Inficirte Gebärmutter. Rechts infieirtes Horn, links normales Horn. Versuch 9. Vergr. $10: 1$.

Fig. 10. Inficirtes Gebärmutterhorn, höher hỉnauf. Versuch 11. Vergr. 13:1.

Eig. 11. Inficirtes Gebärmutterborn. Versuch 13. Vergr. 13:1.

Fig. 12. Erweitertes Gebärmutterhorn. Versuch 25. Vergr. 14:1.

Fig. 13. Wand des Gebärmutterhorns. Versuch 25. Vorgr. 20 1 .

\section{Tafel VIII-IX.}

Figur 1. Versuch 2. Zeiss. Imm. Ocular 2. Vaginalschleimhaut. Streptokokken theils dicht am oberflächlichen Epithel, theils im obersten Theil des Protoplasmas der Zellen, theils in Eiteransammlung im Lumen.

Figur 2. Versuch 2. Zeiss. Imm. Ocular 2. Vaginalschleimhaut. Das oberflächliche Epithel abgelöst, an einer Stelle defect. Streptokokken im Raume zwischen den Zellen und dem Bindegewebe.

Figur 3. Versuch 2. Zeiss. Imm. Ocular 2. Vaginalschleimhaut. Die Lymphräume im Bindegewebe sind mit Streptokokken angefüllt.

Figur 4. Versuch 2. Zeiss. Imm. Ocular 2. Vaginalschleimhaut. Das oberflächliche Epithel an einer Stelle abgelöst. Streptokokken dringen durch diese Oeffnung in das Bindegewebe. Im benachbarten Lymphraum eine Menge Streptokokken.

Figur 5. Versuch 2. Zeiss. Imm. Ocular 2. Bindegewebe an der äusseren Seite der Muscularis vaginae. Streptokokken in Lymphräumen und Bindegewebsspalten, aber nicht in den Blutgefässen.

Figur 6. Versuch 2. Zeiss. A. A. Ocular 4. Quersebnitt der Gebär- mutterwand. Ganz unten die Schleimhaut. Zwischen jeder der Muskelschichten eine breite Bindegewebsschicht, deren Lymphräume zu einem Theil mit Streptokokken gefüllt sind. Einige solche finden sich auch im zunächst liegenden 
Bindegewebe. In und bei der äusseren, nach der P eritonealhöhle zu liegenden schmalen Bindegewebsschicht sind reichlich Streptokokken zu finden.

Fig. 7. Versuch 2. Zeiss. Imm. Ocular 2. Des oberfläohlichen Epithels entblöstes. Bindegewebe von der Gebärmutterschleimhaut, in welches Streptokokken eingedrungen sind.

Figur 8. Versuch 2. Zeiss. Imm. OcuJar 2. Oberflächliches Epithel der Gebärmutterschleimhaut. Durch eine Oeffnung zwischen den Zellen dringen Streptokokken ein.

Figur 9. Versuch 3. Zeiss. Imm. Ocular 4. Ein kleines Blutgefäss aus dem Bindegewebe um die Scheide Streptokokken enthaltend, die anch im benachbarten Bindegewebe zu finden sind.

Figur 10. Versuch 3. Zeiss. Imm. Ocular 4. Eine Streptokokkenkette in Scheidenmusculatur.

Figur 11. Versuch 3. Zeiss. Imm. Ocular 4. Beibehaltenes Scheidenepithel, Streptokokken im zunächst darunterliegenden Bindegewebe.

Figur 12. Versuch 3. Zeiss. Imm. Ocular 4. Scheidenschleimbaut. Vermuthlich durch die Oeffnung im oberflächlichen Epithel sind die Streptokokken in das unterliegende Bindegewebe und ein darin befindliches Lymphgefäss bineingelangt.

Figur 13. Versuch 3. Zeiss. Imm. Ocular 4. Gebärmutterschleimhaut. Das oberflächliche Epithel an einer Stelle abgelöst. Streptokokken finden sich an der Oberfläche des blossgelegten Bindegewebes, nicht unter beibehaltenem oberflächlichen oder Drüsenepithel.

Figur 14. Versuch 4. Zeiss. Imm. Ocular 4. Gebärmutterschleimhaut. Oberflächliches Epithel mit einigen Zellen mit Anhäufung von Kernen. Leukosyten mit pyknotischem Kern zwischen den Epithelzellen.

Figur 15. Versuch 4. Zeiss. Imm. Ocular 4. Leukocyten mit pyknotischem Kern im Bindegewebe der. Gebärmutterschleimhaut.

Figur 16. Versuch 4. Zeiss. Imm. Ocular 4. Gebärmutterdrüse mit theils nach dem Boden zu beibehaltenen, nach der Mündung za veränderten Zellen; in diesen letzteren Kernanhäufungen. Nach links zu sind die Zellen weggefallen und durch Leukocyten mit pyknotischem Kern ersetzt, welche auch an anderen Stellen in die Drüse zwischen den Drüsenzellen hineindringen: Im Lumen Leukocyten und Streptokokken, von denen einige auch unter dem Drüsenepithel im oberflächlichen Theil der Drüse zu sehen sind.

Figur 17. Versuch 4. Zeiss. Imm. Ocular 4. Gebärmutterschleimhant. An einer Stelle, wo das oberflächliche Epithel defect ist, dringen Streptokukken in das blossgelegte Bindegewebe ein. Eiterkörperchen an derselben Stelle.

Eigur 18. Versuch 4. Zeiss. Imm. Ocular 4. Oberflächliches Epithel von der Gebärmutterschleimhaut, abgeplattet.

Figur 19. Versuch 4. Zeiss. Imm. Orular 4. Gebärmutterdrüse, wo die Zellen zerstört oder degenerirt und losgelöst, im Lumen liegen, das ausserdem mit Leukocyten und Streptokokken angefüllt ist.

Figur 20. Versuch 4. Zeiss. Imm. Ocular 2. Gebärmutterschleimhaut. Links der Anfang einer Drüse. Das oberflächliche Epithel verschwunden. Der oberflächliche Theil des Bindegewebes kleinzellig infiltrirt. Streptokokken sind in dasselbe eingedrungen und finden sich ausserdem unter den heraustretenden Leukocyten. 
Figur 21. Versuch 4. Zeiss. Imm. Ocular 2. Gebärmutterschleimbaut. Rechts degenerirte Drüsenzellen. Streptokokken im Lumen der Drüse sowie in unterliegenden Bindegewebe.

Figur 22. Versuch 4. Zeiss. Imm. Ocular 2. Gebärmutterschleimhant. Anhäufung von mononueleären Leukocyten unter dem oberflächlichen Epithel.

Figur 23. Versuch 6. Zeiss. Imm. Ocular 4. Gebärmutterschleimhaut mit stark dilatirten Blutgefässen.

Figur 24. Versuch 11. Zeiss. Imm. Ocular 4. Gebärmutterschleimhaut. Oberflächliches Epithel, deren Protoplasma gleichsam im Zerfall mit abgenagtem Rande begriffen ist.

Figur 25. Versuch 11. Zeiss. Imm. Ocular 4. Die Oberfläche der Gebärmutterschleimhaut. Das oberflächliche Epithel grösstentheils zerstört. Längs and in dem blossgelegten Bindegewebe Leukocyten. Streptokokken in Venen, Lymphgefässen und dem benachbarten Gewebe sowie im Lumen längs der Oberfläche der Epithelzellen der Schleimbaut.

Figur 26. Versuch 11. Zeiss. Imm. Ocular 2. Die Gebärmuttersehleimhaut in verschiedener Weise verändert bei starker Verdünnung der Wand. a) Das oberflächliche Epithel beibehalten, aber die Zellen niedrig, abgeplattet. Das Bindegewebe sehr dünn. b) Das oberflächliche Epithel zum Theil verschwunden, eine sehr kurze Drüse, das Bindegewebe sehr dünn. c) Das oberflächliche Epithel verschwunden, kleinzellige Infiltration des Bindegewebes, Auswanderung von Leukocyten aus diesem.

Figur 27. Versuch 13. Zeiss. Imm. Ocular 4. Stäbchenförmige Bakterien längs der Oberfläche des Epithels in Cervicaltheil des Gebärmutterhornes.

Figur 28. Versuch 13. Zeiss. Imm. Ocular 4. Streptokokken auf und unter dem oberflächlichen Epithel im Cervicaltheil des. Gebärmutterhornes.

Figur 29. Versuch 13. Zeiss. Imm. Oeular 2. Gebärmutterschleimhaut. Eiter und Streptokokken irn Lumen. Das oberflächliche Epithel zum Theil fort, Streptokokken in dem kleinzellig infiltrirten Bindegewebe.

Figur 30. Versuch 13. Zeiss. Imm. Ocular 2. Gebärmutterschleimhaut an der Oberfläche. Streptokokken nebst Leukocyten im Lumen am oberflächlichen Epithel, dessen Zellen auseinandergegangen sind und Streptokokken in den oberflächlichen Theil des Bindegewebes hineindringen lassen.

Figur 31. Versuch 13. Zeiss. Imm. Ocular 2. Gebärmutterschleimhaut. Eine Anhäufung von Streptokokken tiefer hinein in das Bindegewebe. 

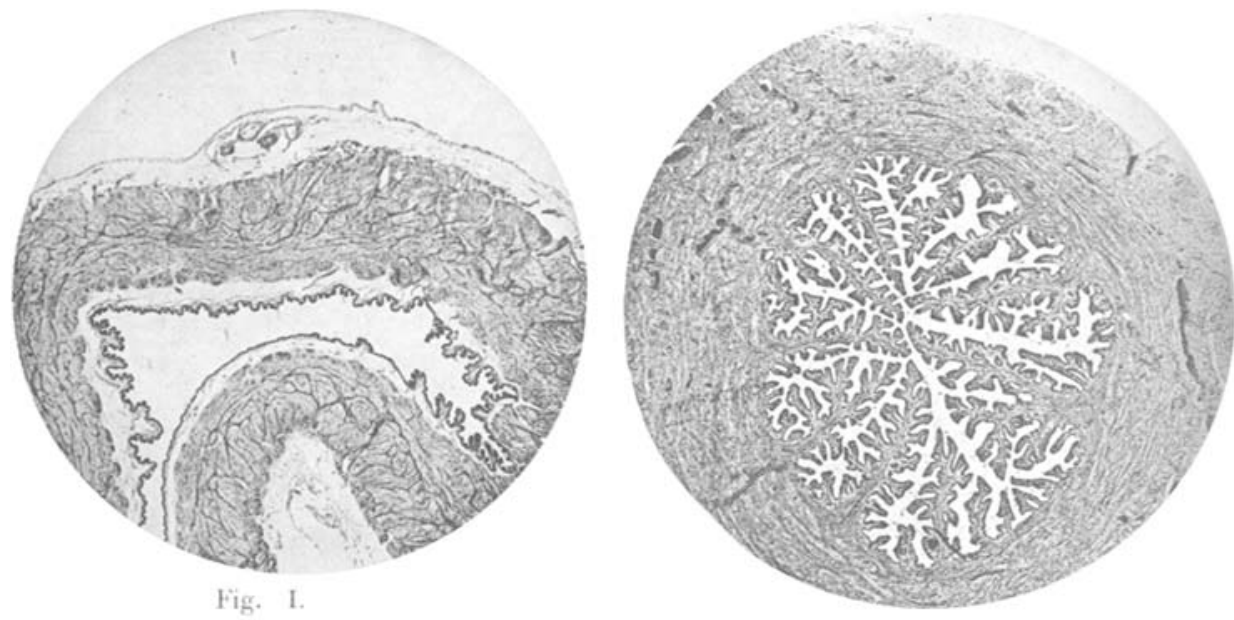

Fig. 11.
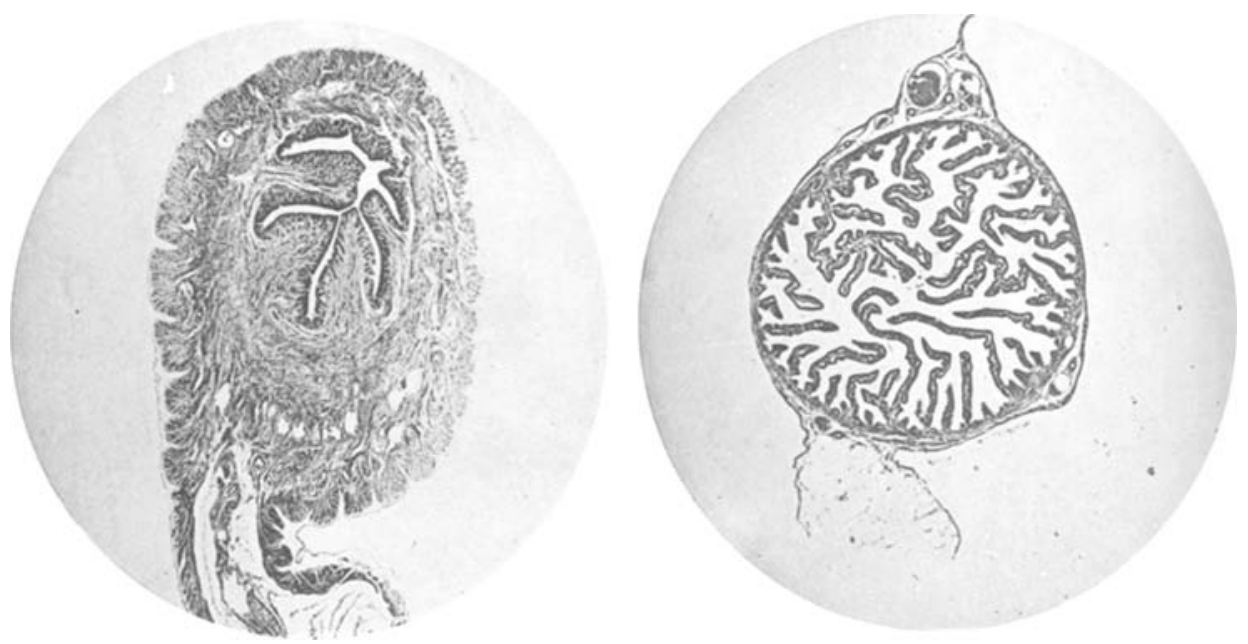

Fig. III

Fig. IV. 


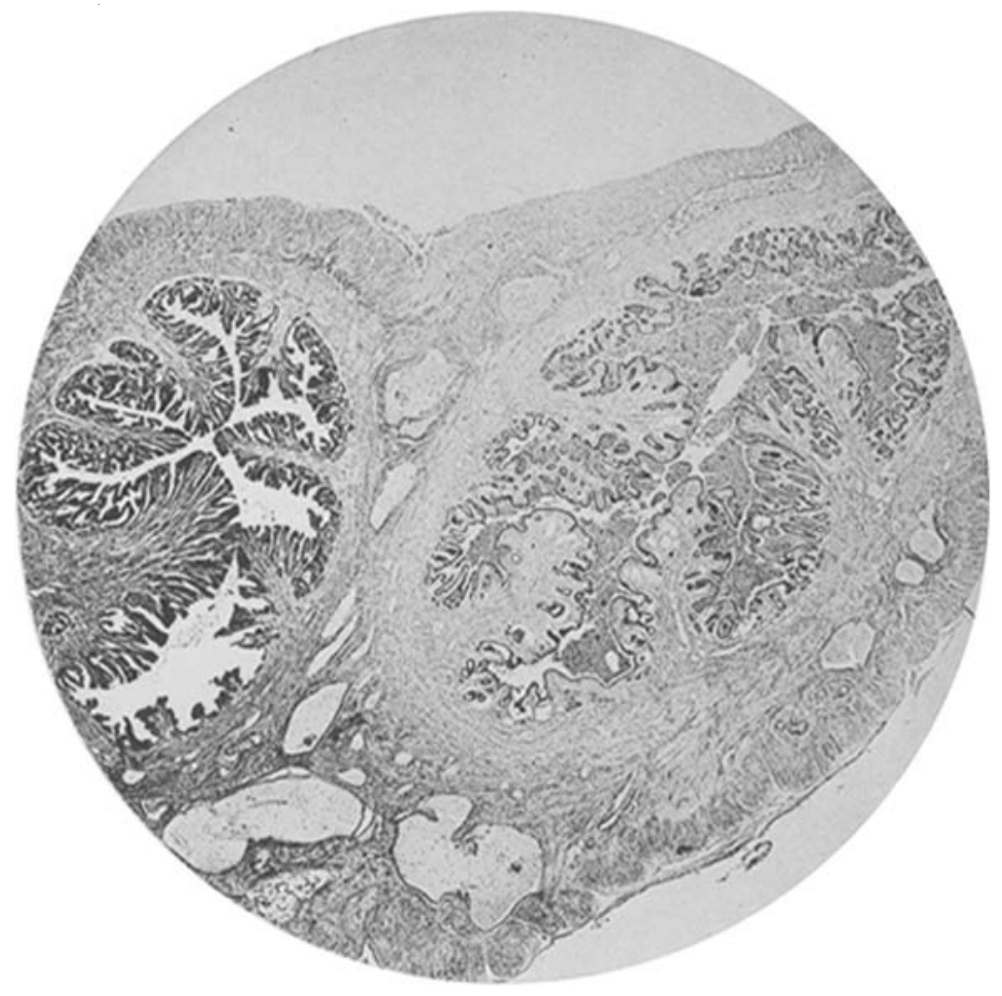

Fig. V.

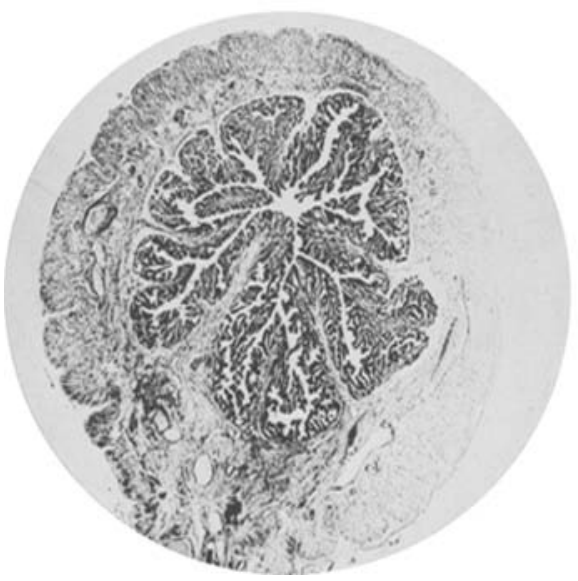

Fig. VII.

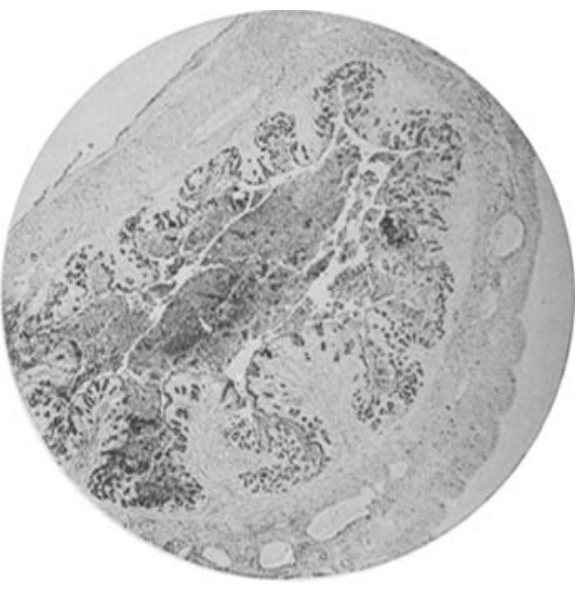

Fig. VI. 


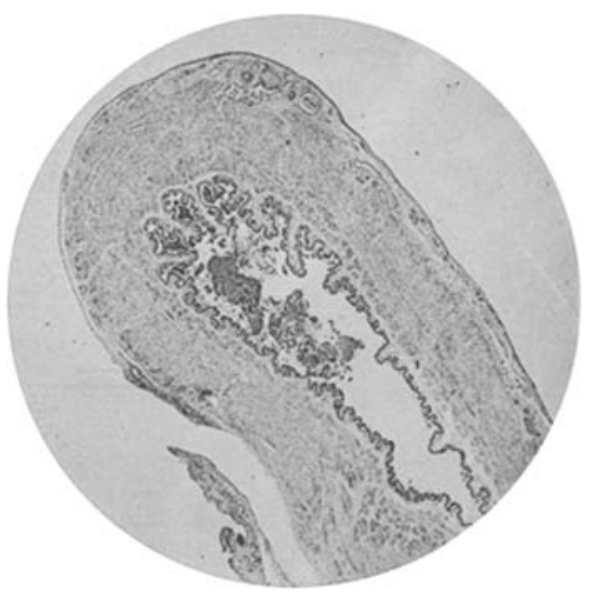

Fig. VIII.

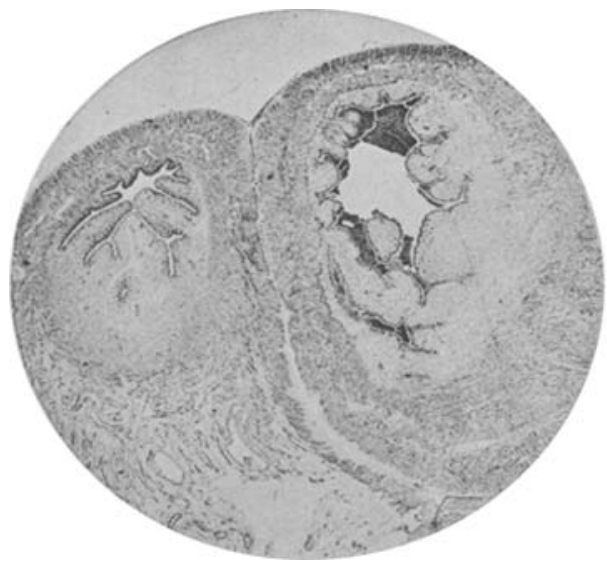

Fig. IX

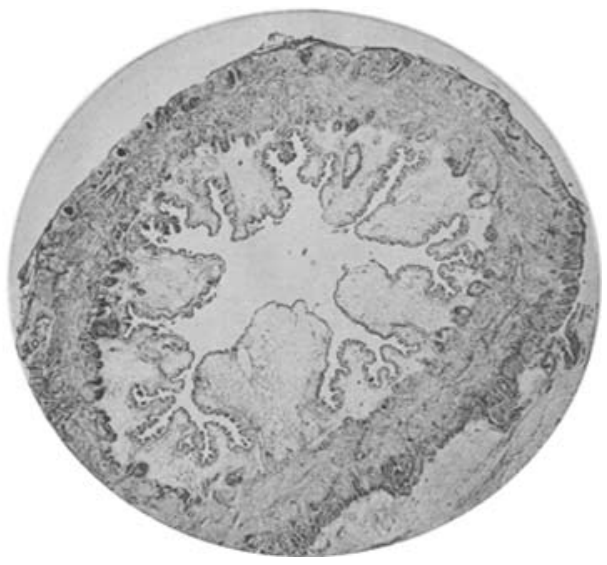

Fig. X. 


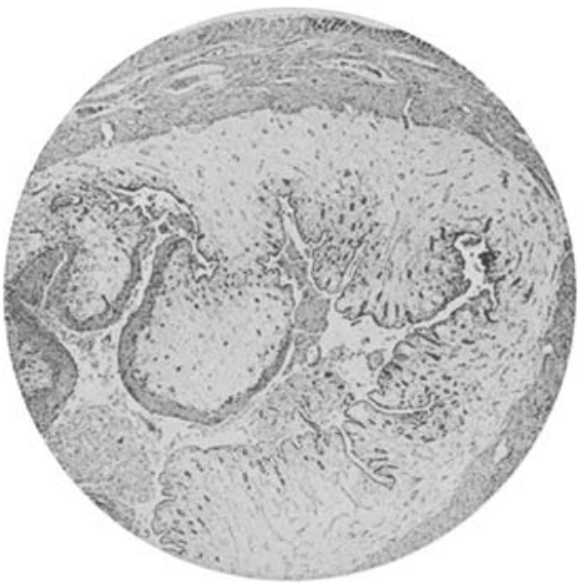

Fig. XI.

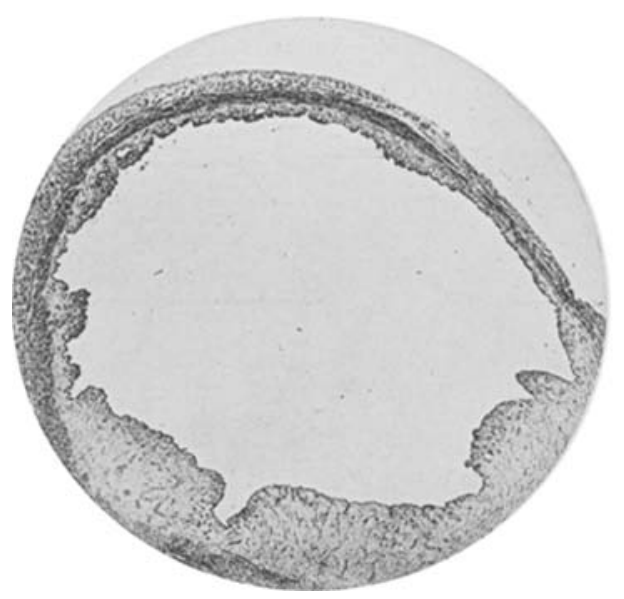

Fig XII.

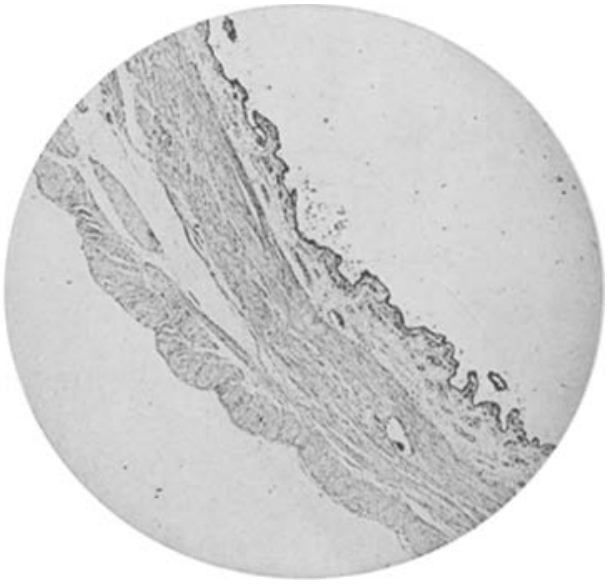

Fig. XIII. 
S

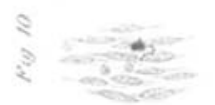

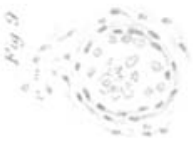

3. 389

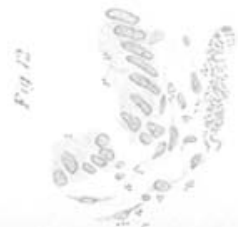

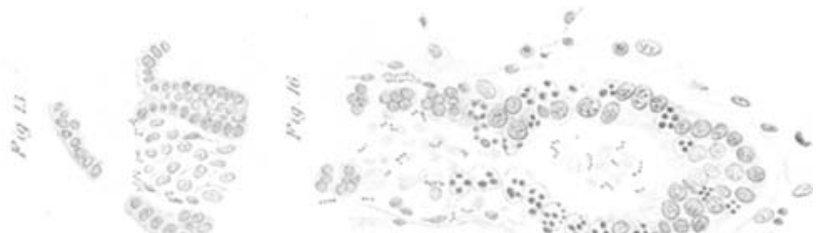

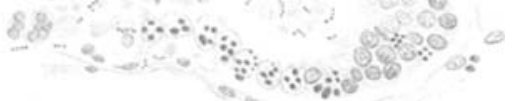

(2)

$3 \log ^{6}$
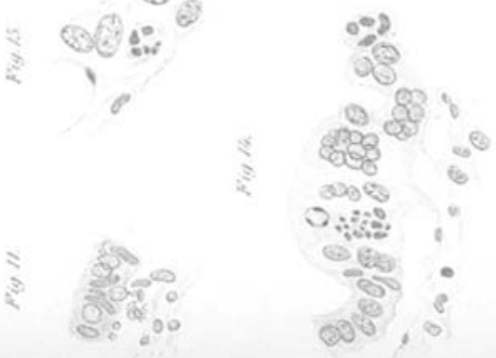

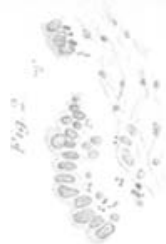
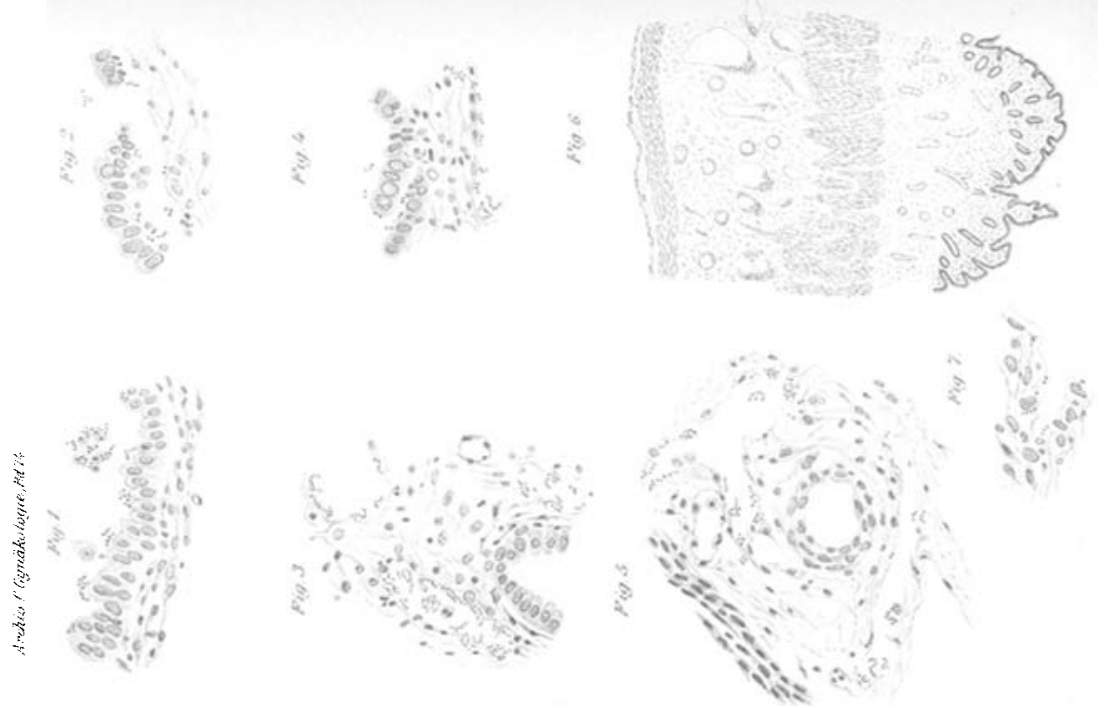
$\stackrel{\vdots}{\vdots}$

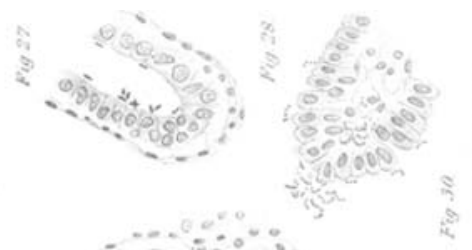

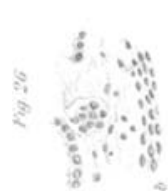

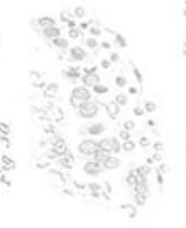
30
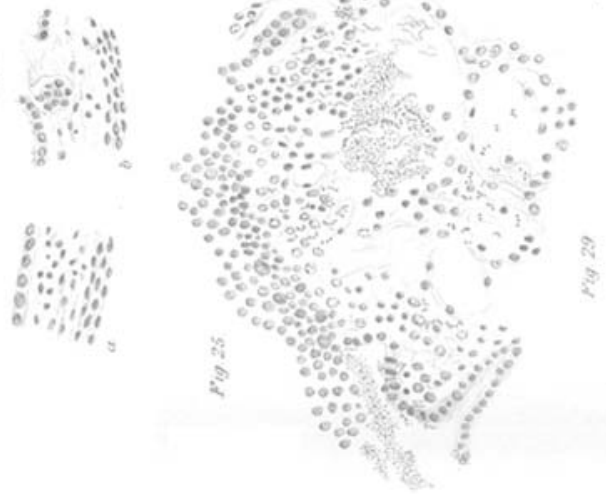

00850
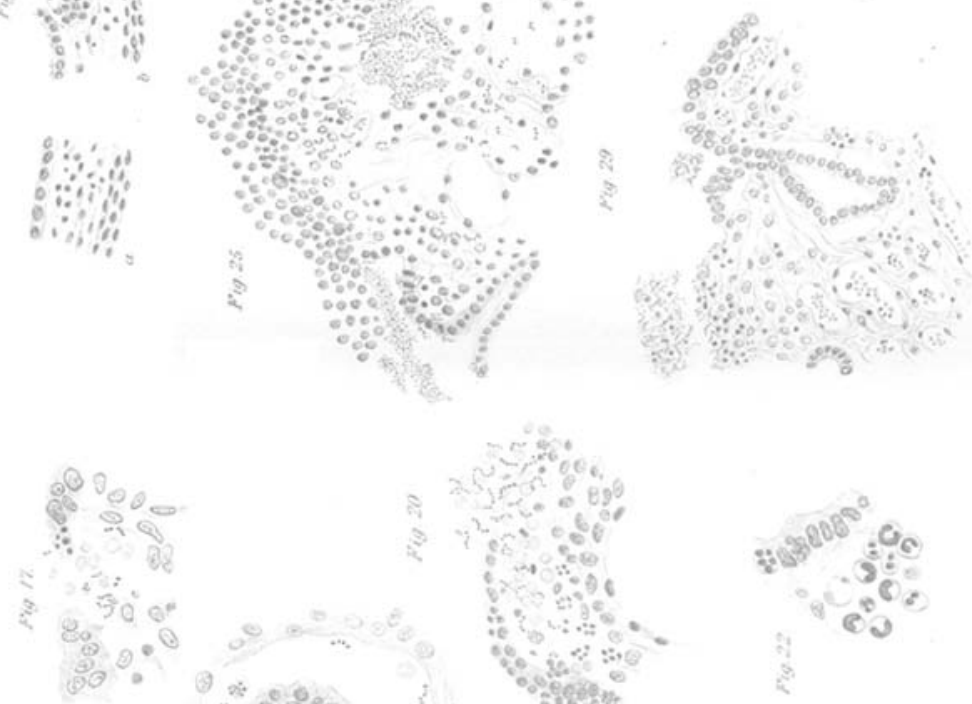

$-26^{\circ}$
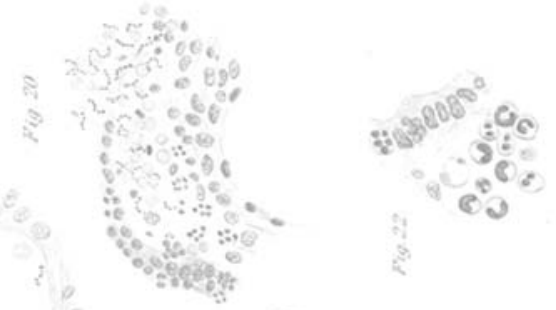

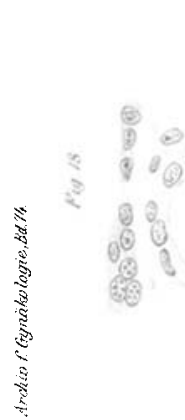
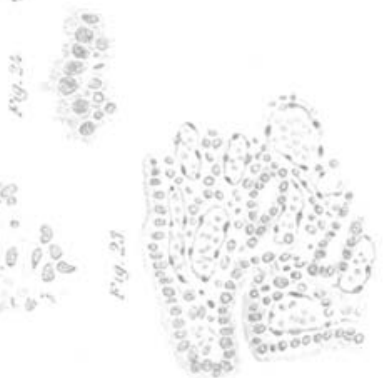


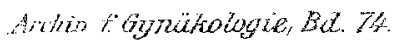

Tat:X.

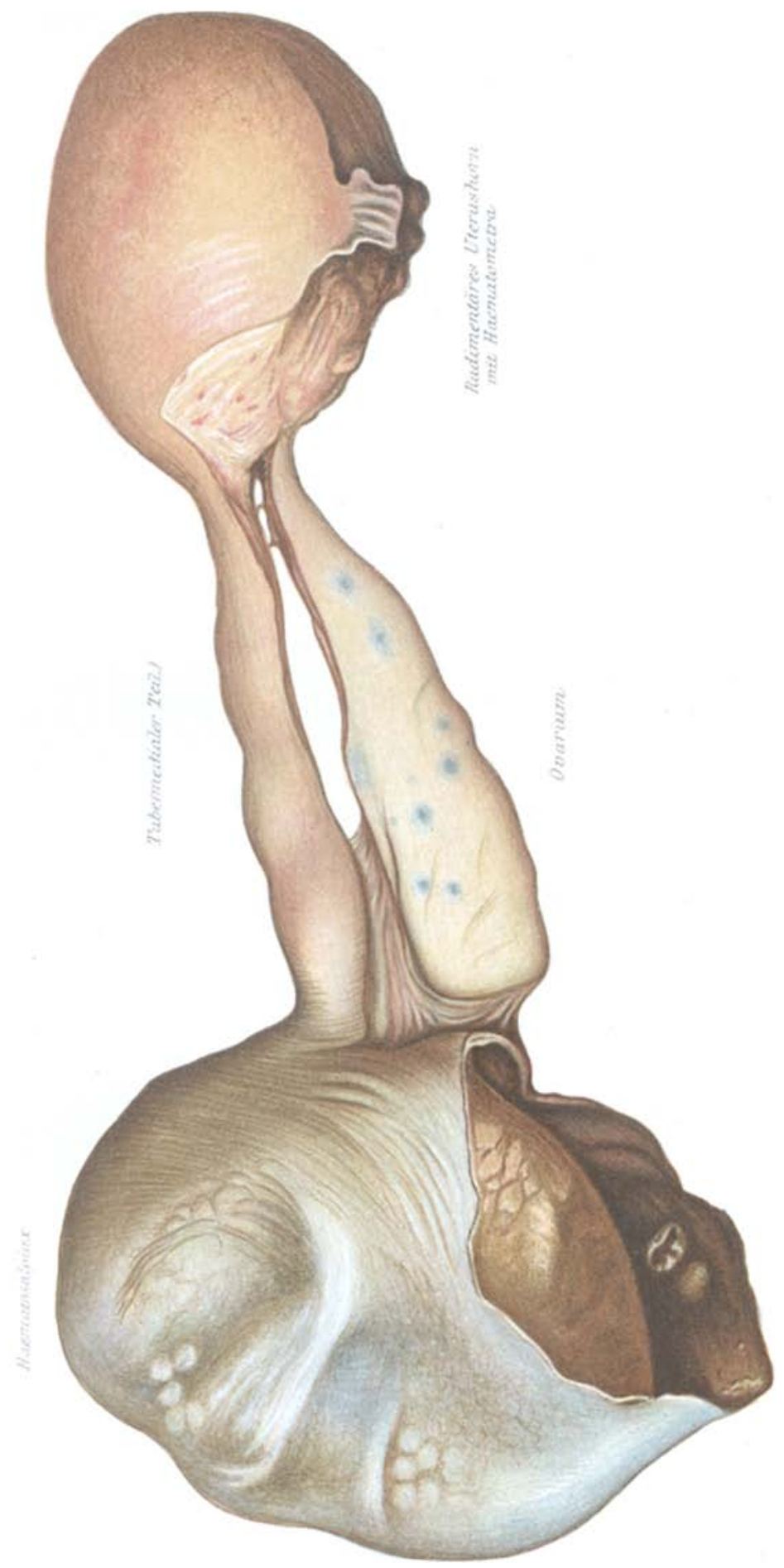

